Report of Investigation 2020-3

\title{
GEOLOGIC MAP OF THE STYX RIVER AREA, LIME HILLS C-1 QUADRANGLE, WESTERN ALASKA RANGE, ALASKA
}

Karri R. Sicard, Alicja Wypych, Evan Twelker, Travis J. Naibert, Lawrence K. Freeman, Rainer J. Newberry, Erik N. Bachmann, David A. Reioux, Amy L. Tuzzolino, and Thomas C. Wright
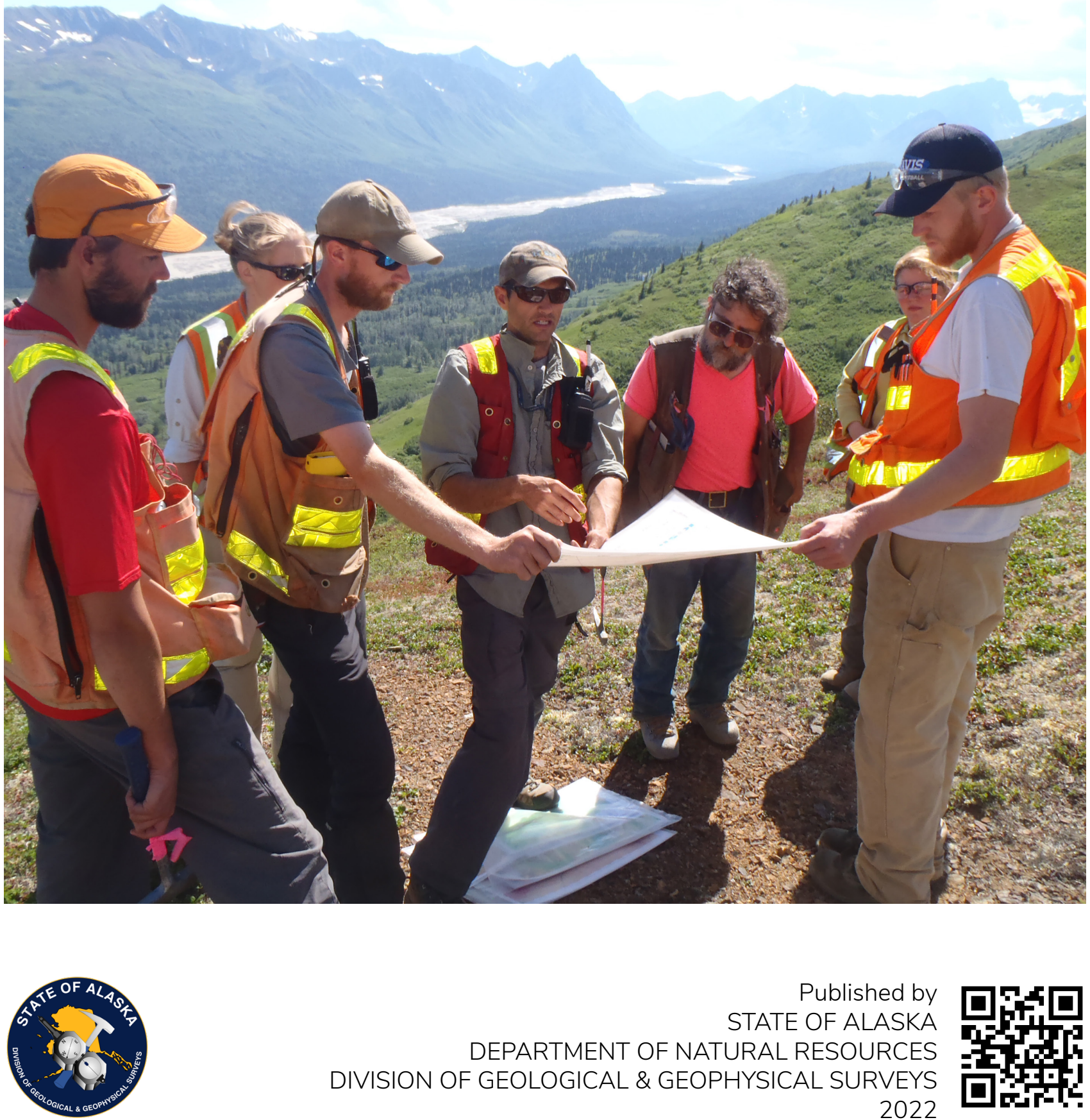

Published by STATE OF ALASKA DEPARTMENT OF NATURAL RESOURCES DIVISION OF GEOLOGICAL \& GEOPHYSICAL SURVEYS

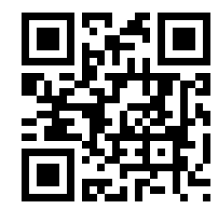


Cover. Mike Roberts (center), senior geologist for Kiska Metals Corp., gives DGGS and associated geologists an overview of the Estelle pluton area geology near the Whistler and Island Mountain porphyry copper-gold deposits, east of the Styx River map area. From left to right: Erik Bachmann, Karri Sicard, Evan Twelker, Mike Roberts, Rainer Newberry, Amy Tuzzolino, and David Reioux. Photo by Larry Freeman, July 2013. 


\section{GEOLOGIC MAP OF THE STYX RIVER AREA, LIME HILLS C-1 QUADRANGLE, WESTERN ALASKA RANGE, ALASKA}

Karri R. Sicard, Alicja Wypych, Evan Twelker, Travis J. Naibert, Lawrence K. Freeman, Rainer

J. Newberry, Erik N. Bachmann, David A. Reioux, Amy L. Tuzzolino, and Thomas C. Wright

Report of Investigation 2020-3

State of Alaska

Department of Natural Resources

Division of Geological \& Geophysical Surveys 


\section{STATE OF ALASKA}

Mike Dunleavy, Governor

\section{DEPARTMENT OF NATURAL RESOURCES}

Corri A. Feige, Commissioner

\section{DIVISION OF GEOLOGICAL \& GEOPHYSICAL SURVEYS}

Steve Masterman, State Geologist and Director

Publications produced by the Division of Geological \&

Geophysical Surveys (DGGS) are available for free download

from the DGGS website (dggs.alaska.gov). Publications on

hard-copy or digital media can be examined or purchased in

the Fairbanks office:

Alaska Division of Geological \& Geophysical Surveys

3354 College Rd., Fairbanks, Alaska 99709-3707

Phone: (907) 451-5010 Fax (907) 451-5050

dggspubs@alaska.gov|dggs.alaska.gov

\section{DGGS publications are also available at:}

Alaska State Library,

Historical Collections \& Talking Book Center

395 Whittier Street

Juneau, Alaska 99811

Alaska Resource Library and Information Services (ARLIS)

3150 C Street, Suite 100

Anchorage, Alaska 99503

\section{Suggested citation:}

Sicard, K.R., Wypych, Alicja, Twelker, Evan, Naibert, T.J., Freeman, L.K., Newberry, R.J., Bachmann, E.N., Reioux, D.A., Tuzzolino, A.L., and Wright, T.C., 2022,

Geologic map of the Styx River area, Lime Hills C-1 Quadrangle, Western Alaska Range, Alaska: Alaska Division of Geological \& Geophysical Surveys Report of Investigation 2020-3, p., 51 p., 1 sheet, scale 1:63,360. doi.org/10.14509/30424
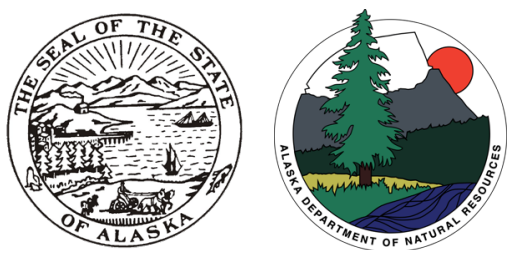


\section{Contents}

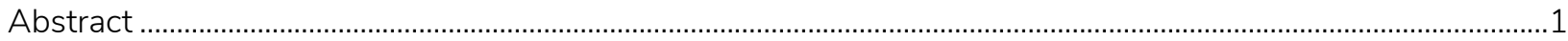

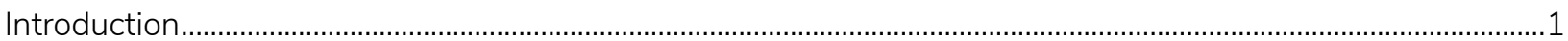

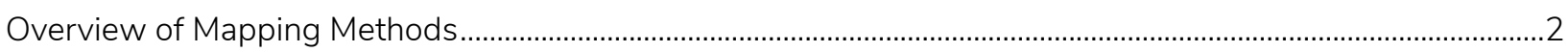

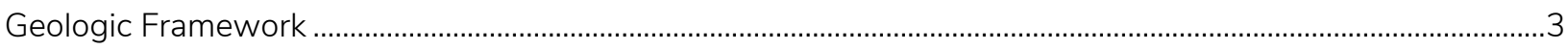

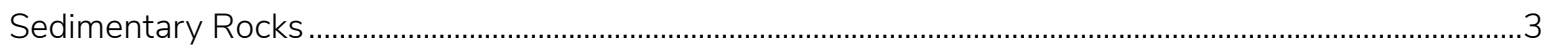

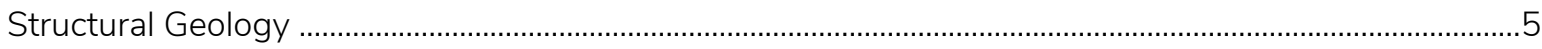

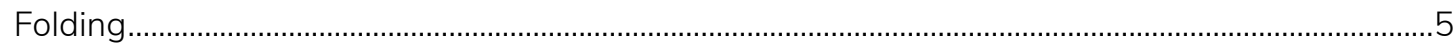

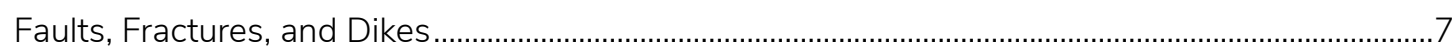

Regional Magmatic Periods .................................................................................................................. 10

Petrology and Geochemistry of Plutonic and Volcanic Rocks ....................................................................13

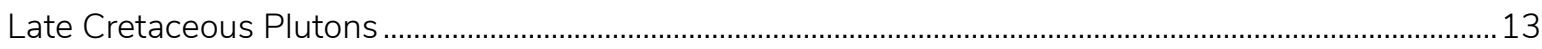

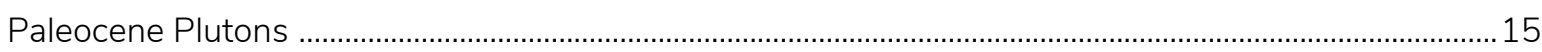

Miocene to Eocene Intrusions .......................................................................................................................... 17

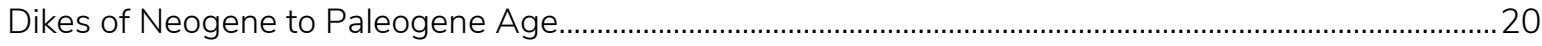

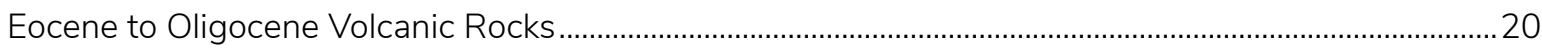

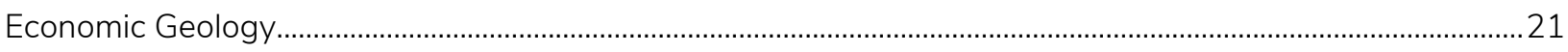

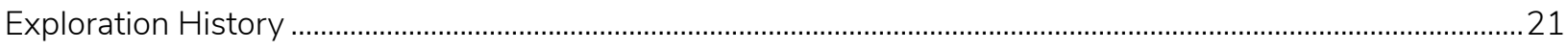

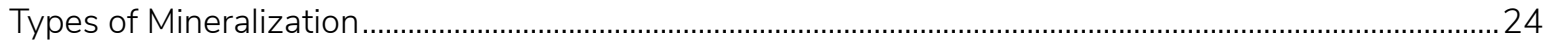

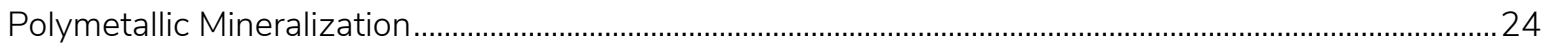

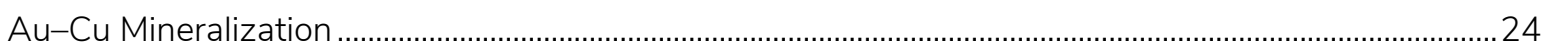

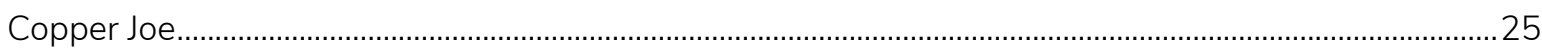

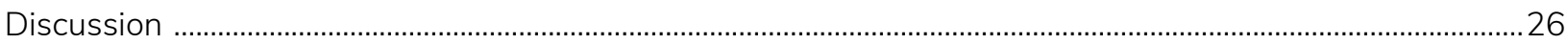

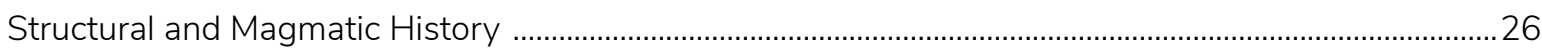

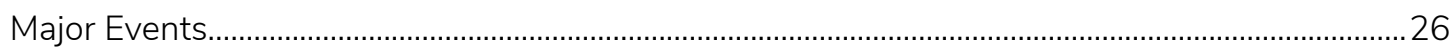

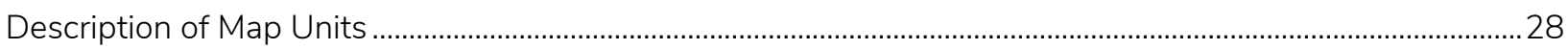

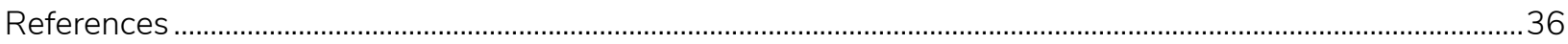

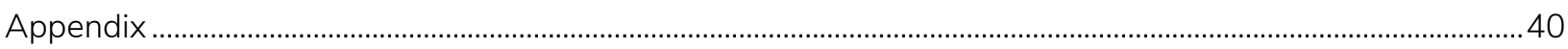

\section{Figures}

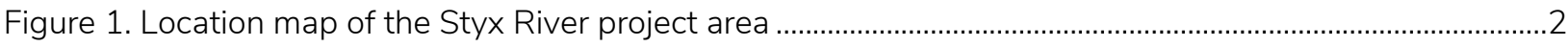

Figure 2. Overview of the airborne geophysical surveys from DGGS ................................................................

Figure 3. Photos showing folding in Kahiltna assemblage sedimentary rocks .........................................................

Figure 4. Photos showing sedimentary structures from a well indurated siltstone to sandstone in finely bedded, turbiditic Kuskokwim group.........................................................................................................

Figure 5. Bedding planes of the Whistler petrofacies of the Kahiltna assemblage from the field area showing the northwest-southeast compression of the closing Kahiltna basin ..........................................7

Figure 6. Photos showing outcrop scale views of the sedimentary rocks show evidence of mesoscale folding, slip along bedding planes in the form of crystal fiber steps, slickenlines, tension gashes, and blocky beds.

Figure 7. Planes and poles to planes of mapped faults and fractures in the field area showing two main trends and photos showing high angle brittle faulting ...........................................................................

Figure 8. Poles to planes of all the dikes and measured veins in the field area and photos showing a near vertical lamprophyre dike within the Mount Estelle pluton ...................................................................11

Figure 9. Geochemical plots of plutonic and igneous rocks .................................................................................. 14

Figure 10. Multi rare earth element plots for the units observed in the map area.............................................16

Figure 11. Classification of granitoids ............................................................................................................ 17 
Figure 12. Photos of Mount Estelle pluton displaying typical textures of the biotite-hornblende monzodiorite, with copper related malachite staining near a vein and showing a near vertical mafic dike (northwest trending), with thin distal tourmaline and magnetite veins

Figure 13. Photos of the Crystal Creek granite

Figure 14. Photos showing the complex relationship between the Tmp and the volcanic rocks in the Merrill Pass pluton.

Figure 15. Trace and major element groups and variations for silicic units

Figure 16. Photos showing dike and volcanic rock textural variations in the dike 'pucks' used for XRF analysis, a dike swarm in the northeast corner of the map area, the view looking south at a dike swarm, and a photo showing the dikes are exposed.

Figure 17. Photos showing nearly flat-lying volcanic layers, volcaniclastic rock with a range of clast sizes, textures, matrix material, and compositions, and field outcrop showing flattened fiamme or pumice in a volcanic rock

Figure 18. Photo showing Hades Gulch within the Copper Joe area near station 13RN204A.......................24

Figure 19. Bivariate trace element plots showing rock geochemical data from this project

\section{Tables}

Table 1. Descriptive statistics for magnetic-susceptibility values by map unit .3

Table 2. Relevant geochronology of the Styx River area.

\section{Map Sheet}

Geologic map of the Lime Hills C-1 Quadrangle, Western Alaska Range, Alaska 


\title{
GEOLOGIC MAP OF THE STYX RIVER AREA, LIME HILLS C-1 QUADRANGLE, WESTERN ALASKA RANGE, ALASKA
}

Karri R. Sicard ${ }^{1}$, Alicja Wypych ${ }^{1}$, Evan Twelker ${ }^{1}$, Travis J. Naibert ${ }^{1}$, Lawrence K. Freeman², Rainer J. Newberry ${ }^{3}$, Erik N. Bachmann², David A. Reioux², Amy L. Tuzzolino², and Thomas C. Wright ${ }^{2}$

\begin{abstract}
This 1:63,360-scale geologic map of the Styx River area (Lime Hills C-1 Quadrangle) in the western Alaska Range records a history of sedimentation, magmatism, volcanism, and mineralization spanning from Late Jurassic to Neogene time. This map and report are the product of airborne geophysical surveys and four weeks of field work in 2013 by Mineral Resources section geologists at the Alaska Division of Geological \& Geophysical Surveys (DGGS); it improves existing bedrock geologic mapping by refining contacts, subdividing major units, and identifying new dikes and faults. The map and supporting geochemical, petrologic, and geochronologic data foster a better understanding of the area's geology and mineral potential.

The Styx River map area is underlain by Late Jurassic to Late Cretaceous Kahiltna assemblage sedimentary rocks, which formed in a slowly closing basin between the southern edge of the Farewell terrane and the northern edge of the Wrangellia composite terrane prior to its emplacement along the Alaskan continental margin (Box and others, 2019). Multiple series of plutons intruded this area during and after closure of the basin. In the western Alaska Range, Mid-Cretaceous to Oligocene intrusive rocks document at least five magmatic flare-up episodes between 102 and 28 Ma, each lasting 10 m.y. (Todd and others, 2017). Plutons in the Styx River map area post-date the two first phases; major plutons include the Late Cretaceous South Fork gabbro and Mount Estelle monzogranite, the Paleocene Crystal Creek granite, McKinley sequence granites, Styx River granite, and the Eocene Merrill Pass granite. Major oxide and trace element data helped differentiate distinct compositions of plutons and refine map contacts. Late Cretaceous granodiorite to gabbro plutons contrast in composition with granites from the Paleocene. Previously unmapped mafic dikes trend generally northwest, while major high-angle fault sets trend northwest, north-south, and north-northeast.

Mineralization in the Lime Hills C-1 Quadrangle is dominated by: 1) Au-Cu mineralization associated with the margins of the latest Cretaceous Mount Estelle pluton; 2) widely scattered Ag-bearing polymetallic occurrences associated with dikes, veins, and faults of a range of ages and; 3) the Miocene-age Copper Joe porphyry copper prospect.
\end{abstract}

\section{INTRODUCTION}

The DGGS Mineral Resources section geologists conducted four weeks of fieldwork on the Styx River project in the Lime Hills C-1 Quadrangle during the summer of 2013. The map area is located about 100 miles northwest of Anchorage (fig. 1) and is bounded by the Tordrillo Mountains to the southeast and the Revelation Mountains to the west. This project was part of the State of Alaska's Airborne Geophysical/Geological Mineral Inventory (AGGMI) program. During the 2013 project DGGS geologists described and sampled bedrock units, measured structural features, and examined and sampled mineral occurrences. Bedrock geologic

\footnotetext{
${ }^{1}$ Alaska Division of Geological \& Geophysical Surveys, 3354 College Rd., Fairbanks, Alaska 99709-3707

${ }^{2}$ Formerly at Alaska Division of Geological \& Geophysical Surveys, 3354 College Rd., Fairbanks, Alaska 99709-3707

${ }^{3}$ University of Alaska Fairbanks, Department of Geosciences-Geology, Geophysics, and Geography, P.O. Box 755780,

Fairbanks, AK 99775-5780
} 


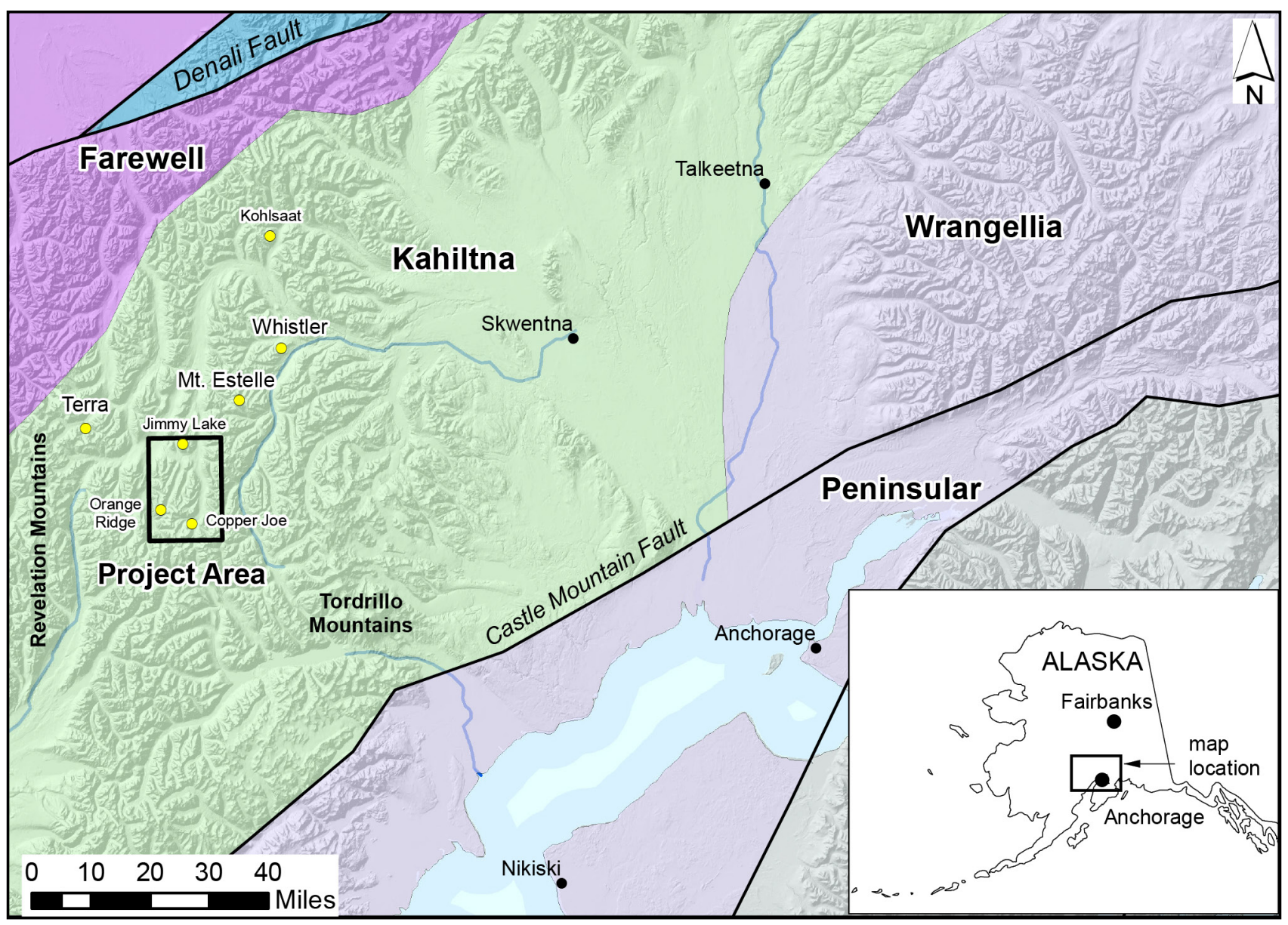

Figure 1. Location of the Styx River map area, Lime Hills C-1 Quadrangle (black rectangle). The colored polygons highlight terranes (modified from Colpron and Nelson, 2011). Note the location of the project area relative to the Denali-Farewell Fault system. The study area is located near the Mt. Estelle, Whistler, Terra, and Copper Joe prospects. The area is near the northern end of the modern volcanic arc associated with the Alaska-Aleutian subduction zone.

mapping was a significant component of this fieldwork and resulted in a new 1:63,360-scale geologic map (sheet 1 ) that helped refine contacts, subdivide major units, identify new dikes and faults, and shed light on the structural history of the area. The DGGS Styx River airborne magnetic and electromagnetic datasets (Burns and others, 2019) were used to identify normally and reversely magnetized intrusions, variability in magnetic susceptibility and pluton oxidation states, and fault locations. Supporting geochemical and geochronological data helped refine the area's geologic history and understanding of its mineral potential (Sicard and others, 2014a, 2014b; Benowitz and others, 2014; Todd and others, 2017). Collaboration between DGGS, the U.S. Geological Survey (USGS), and private industry allowed for the integration of a large dataset and enhanced interpretations.

\section{OVERVIEW OF MAPPING METHODS}

This geologic map and report draw on work completed by DGGS in 2013, as well as prior work by the USGS (Gamble and others, 2013). The 2013 DGGS project included approximately 200 person-days of bedrock geologic mapping in the Lime Hills C-1 Quadrangle and at nearby prospects and deposits. DGGS geologists collected 1,863 rock and structure stations using Trimble Juno T41/5 WAAS-enabled GPS devices with a reported locational error of $1 \mathrm{~m}$, running ArcGIS for Windows Mobile. Latitude and longitude were collected in 
the WGS84 datum and are reported in NAD1983. Data were merged into an ArcGIS geodatabase. The map area is mostly covered by the Styx River airborne magnetic and electromagnetic geophysical survey (fig. 2; Burns and others, 2019), which greatly facilitated extrapolation of contacts and faults through areas of surficial deposits, glaciation, and inaccessible terrain. To aid in interpretation of the magnetic survey, geologists collected handheld magnetic susceptibility measurements from outcrop and float in units of Systemé International (SI). Approximately 2 to 6 measurements were taken at each station using Terraplus KT 5, 6, 9, and 10 hand-held magnetic susceptibility meters. Measurement surfaces and degree of oxidation varied, and no effort was made to assess or measure the effects of remnant magnetization, therefore, the data should be considered semi-quantitative. Mean values and ranges are reported by map unit in table 1 .

\section{GEOLOGIC FRAMEWORK}

The Lime Hills C-1 Quadrangle includes folded Kahiltna basin sedimentary rocks, which have been intruded by at least three separate ages of plutons, cut by faults and dikes, covered by a thick section of volcanic rocks, and subsequently faulted and exhumed.

Understanding the changing stress regime and the structural fabric of the western Alaska Range is key for piecing together the magmatic emplacement, mineralization, and deformation throughout the area. Major fault sets in the map area are generally high angle and trend northwest, north-south, and north-northeast. Fold traces trend northeast, perpendicular to shortening direction. These structural and magmatic trends in the Styx River area are a product of the overall convergence, subduction, and subsequent magmatism throughout the western Alaska Range.

\section{Sedimentary Rocks}

Sedimentary rocks of the Late Jurassic to Late Cretaceous Kahiltna assemblage formed in a slowly closing basin between the southern edge of the Farewell terrane and the northern edge
Table 1. Descriptive statistics for magnetic-susceptibility values $\left(\times 10^{-3} \mathrm{SI}\right)$ by map unit. Each data point $(\mathrm{n})$ represents the mean of 3 to 5 individual measurements performed on outcrop material using a handheld magnetic-susceptibility meter.

\begin{tabular}{ccc} 
Unit & Average & Count \\
Pev & 1.73 & 71 \\
\hline Pevc & 1.49 & 93 \\
\hline Emg & 1.15 & 119 \\
\hline Pesg & 1.38 & 47 \\
\hline Pecg & 0.30 & 44 \\
\hline Pems & 2.21 & 22 \\
\hline Kem & 0.83 & 29 \\
\hline Ksg & 1.82 & 41 \\
\hline Ksm & 0.10 & 4 \\
\hline Kkw & 0.71 & 75 \\
\hline KJk & 1.59 & 4 \\
\hline NPedf & 0.97 & 146 \\
\hline NPedm & 3.93 & 79 \\
\hline & & 774
\end{tabular}

of the Wrangellia composite terrane prior to its emplacement along the Alaska continental margin (Ridgeway and others, 2002; Box and others, 2019). Deposition of these 3- to 5-km-thick, turbiditic sediments records the initial collision of the Wrangellia island-arc assemblage with the continental margin in the Kahiltna basin. The overlap sediments of the Kahiltna assemblage range in age from approximately 100-80 Ma based on minimum detrital zircon ages across the western Alaska Range (Box and others, 2019).

Cretaceous sedimentary rocks in the western Alaska Range were previously divided into the Kahiltna assemblage (northeast of the map area; Kalbas and others, 2007) and the Kuskokwim Group (southwestern part of the map area; Cady and others, 1955). Sedimentary rocks throughout the western Alaska Range were re-categorized into two groups, with six petrofacies, based on new 


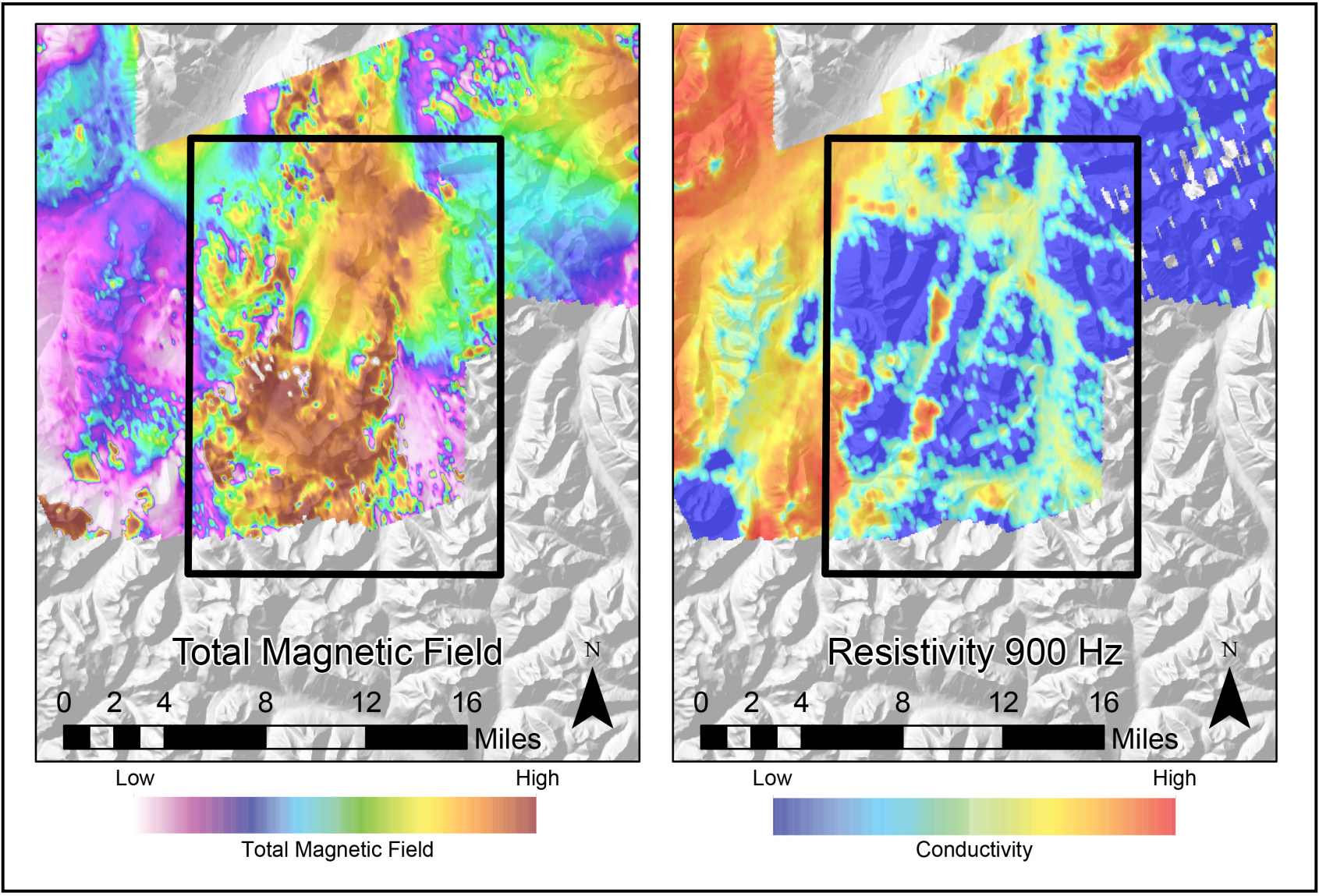

Figure 2. The DGGS Styx River airborne magnetic and resistivity surveys (Burns and others, 2019) were used in the field to aid geologic interpretations. Location of the Lime Hills C-1 Quadrangle is noted (black rectangle).

detrital zircon ages and modal-mineralogy petrographic point counts from detailed and regionally distributed samples (Box and others, 2019; Karl and others, 2016). The Kahiltna assemblage is now subdivided into the Kuskokwim Group and the Koksetna-Clearwater belt. Within this division, the Kuskokwim Group contains the Dalzell, Whistler, and Hayes petrofacies (from northwest to southeast) and the Koksetna-Clearwater belt contains the Old Man, Spring, and Trimble petrofacies (generally northwest to southeast). Detrital zircon age distributions reflect derivation of Kuskokwim Group strata (Dalzell, Whistler, and Hayes petrofacies) from the older Yukon-Tanana, Farewell, and paleo-Alaska margin of North America sources to the north. In contrast, sedimentary rocks of the Koksetna-Clearwater belt to the southeast (Old Man, Spring, and Trimble petrofacies) contain detrital zircons derived from Mesozoic oceanic magmatic arc rocks in the
Peninsular/Wrangellia composite terrane from the Chitina magmatic arc and plutons of the Peninsular terrane (Hults and others, 2013; Karl and others, 2016; Box and others, 2019).

In the Lime Hills C-1 Quadrangle, sedimentary rocks lie within the Whistler petrofacies of the Kuskokwim Group. Two samples from the map area were dated with detrital zircon analysis (DZ) and have youngest DZ peaks of $88.2 \pm 1.1 \mathrm{Ma}$ (sample 13KS126A of this study) and $88.7 \pm 1.9$ Ma (sample 13KS156A of this study; samples W3 and W4 in Box and others, 2019). The samples contain abundant quartz and detrital mica that are typical of sediments on the northwest side of the Kahiltna paleo-basin. The map area is near the division between the two sides of the Kahiltna basin.

In the southeastern Lime Hills C-1 Quadrangle, one sample from a small outcrop of Kokset- 
na-Clearwater belt sandstone was tentatively identified as either the Old Man, Spring, or Trimble petrofacies from thin section (Susan Karl, 2017, written commun; Box and others, 2019). Hence, due to lack of information, petrofacies within the Koksetna-Clearwater belt are left undivided in the map area. The Koksetna-Clearwater belt (KJk) is mapped on top of the Crystal Creek granite ( $\mathrm{PEcg}$ ). The contact relationship between the overlying pre-89 Ma sandstones (Box and others, 2019) and the underlying - 60 Ma Crystal Creek granite could be either an intrusive contact or a low-angle thrust fault contact. Neither contact metamorphism or signs of faulting were observed in the field, so a definitive contact relationship is not possible. We have mapped an intrusive contact on the map sheet.

\section{Structural Geology Folding}

The main structural event of the western Alaska Range was deformation of the Late Jurassic to Late Cretaceous Kahiltna assemblage of sedimentary rocks, which formed in a slowly closing basin between the northern edge of the Wrangellia composite terrane and the Farewell terrane prior to its emplacement along the Alaskan continental margin (Box and others, 2019; Hults and others, 2013). Undeformed plutons dated at 80-76 Ma that cross-cut folds in the Kahiltna sedimentary rocks constrain the deformation of the Kahiltna assemblage (Todd and Jones, 2017). Complex folding and faulting of these sedimentary rocks is only visible from a helicopter or opposing ridgeline because of their large scale and complexities (fig. 3). A regional transect from the Denali Fault (northwest) into the Wrangellia composite terrane (southeast) documents convergence of the complex folding from either side of the basin (Box and others, 2019). Basin folding on the northwest edge is expressed in northwest-verging and overturned folds segmented by thrusts in the Farewell terrane and Kahiltna overlap sediments. In the middle of the basin, the area is intruded by plutons and overlain by volcanic rocks, but the Whistler petrofacies, where observed, was deformed by southeast-verging folds. On the south- east side of the basin and transect the folds transition to southeast-verging and overturned. A large trough of highly magnetic rocks and a gravity low were also noted in the middle of this region, implying crustal differences at depth in the middle of the Kahiltna basin (Saltus and others, 2007).

In the Lime Hills C-1 Quadrangle, meso- to major-scale folding of the Kahiltna assemblage sedimentary rocks is partially obscured by voluminous intrusions, volcanic rocks, and talus slopes. Over 400 structural measurements were made across the map area, and many bedding tops were recorded from preserved sedimentary structures (fig. 4). The folding of the marginal basin, followed by multiple phases of faulting and intrusion since the
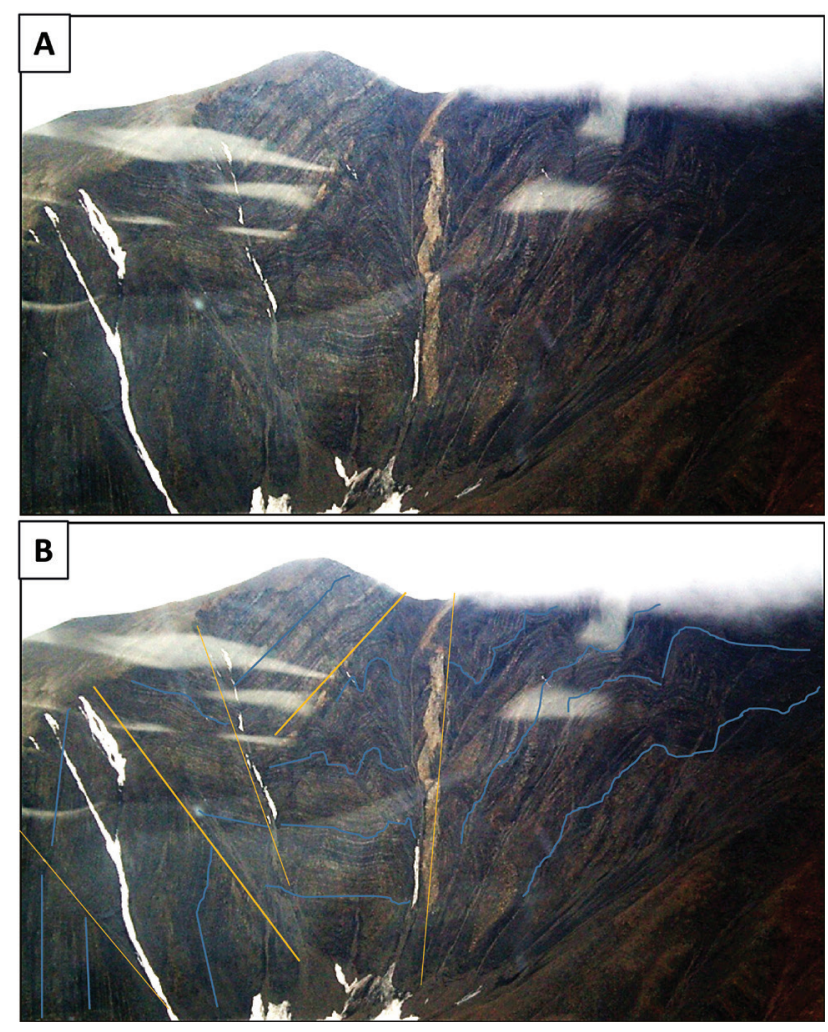

Figure 3. Folding in Kahiltna assemblage sedimentary rocks. A. View looking generally south, a few kilometers northeast of the map area near Mount Estelle. B. Traces of folded bedding (blue) and interpreted faults (yellow) in the sedimentary package. A Felsic dike (pale tan) cuts through the middle section along a vertical fault. The dike appears folded, although it is unclear whether it was folded with the sedimentary rocks, or whether it was intruded near the end of the folding event, or much later. 
Late Cretaceous, contributed to the wide variety of structural attitudes in the map area. Bedding measurements generally trend northeast-southwest and dip southeast or northwest (fig. 5). Faulting and folding were also visible at outcrop scale (fig. 6). Slip planes and crystal-fiber steps of quartz and calcite along bedding planes show evidence of layer-parallel slip, although faults cross-cutting bedding are also present. From the region studied in this map area, and the lack of mapped overturned beds, it
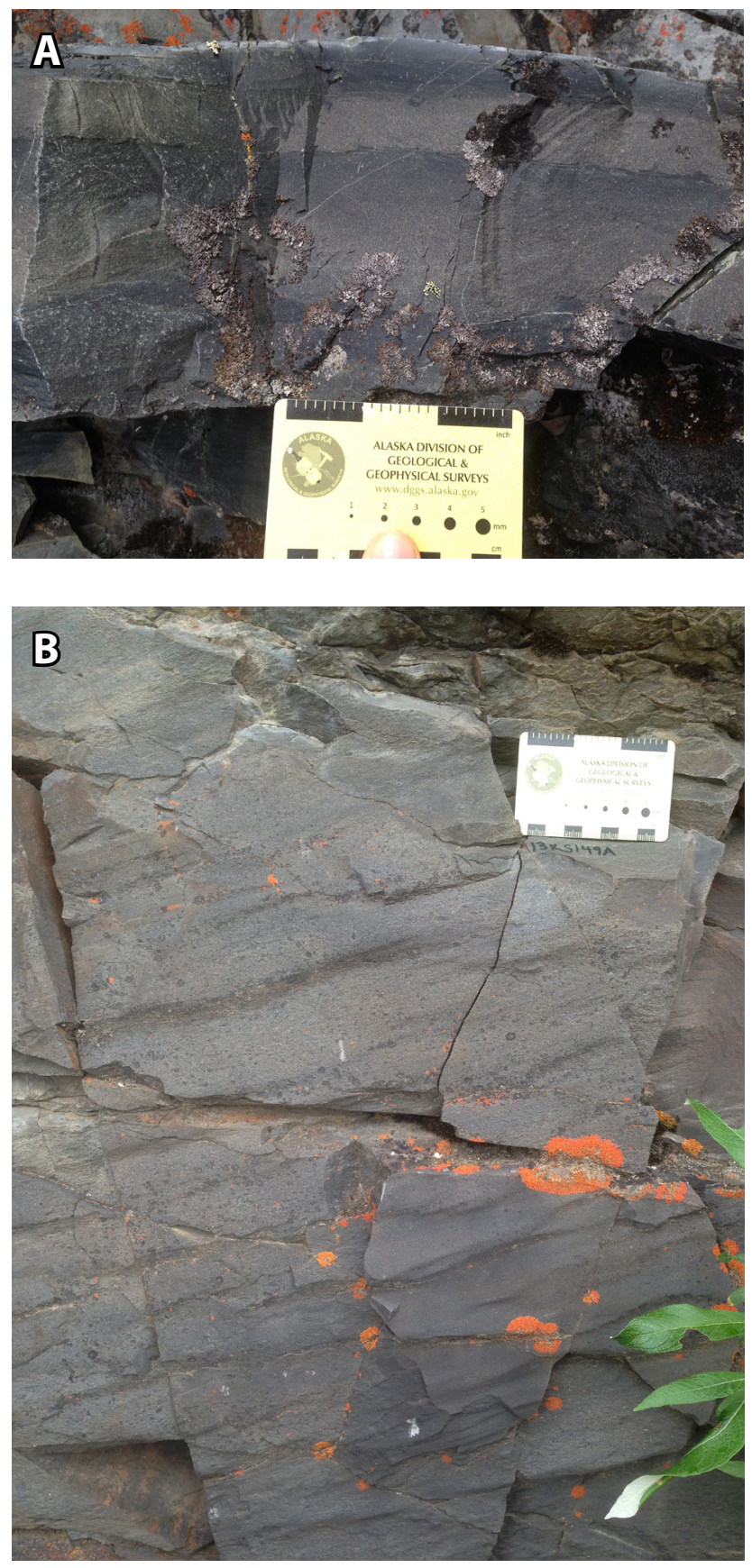

would appear that Kahiltna folding here is generally upright and tight, with northeast-trending, shallowly plunging (but variable) fold axes (fig. 5, fig. 6A). Folding must post-date the youngest beds, and detrital zircon samples both have youngest $\mathrm{DZ}$ peaks of $88.2 \pm 1.1 \mathrm{Ma}$ (sample 13KS126A) and $88.7 \pm 1.9 \mathrm{Ma}$ (sample 13KS156A; samples W3 and W4 in Box and others, 2019). Whistler petrofacies folding is documented about $5 \mathrm{~km}$ east of the map area as crosscut by the $-76 \mathrm{Ma}$ Whistler pluton (Box and others, 2019). From the stereonet data, it is clear that the main Kahiltna deformation is the result of northwest-southeast compression. Possible synchronous strike-slip displacement may have occurred with that folding, but little supporting data is available. The relationship of folding with dikes is complex because many dikes cross-cut the sedimentary layers and some follow

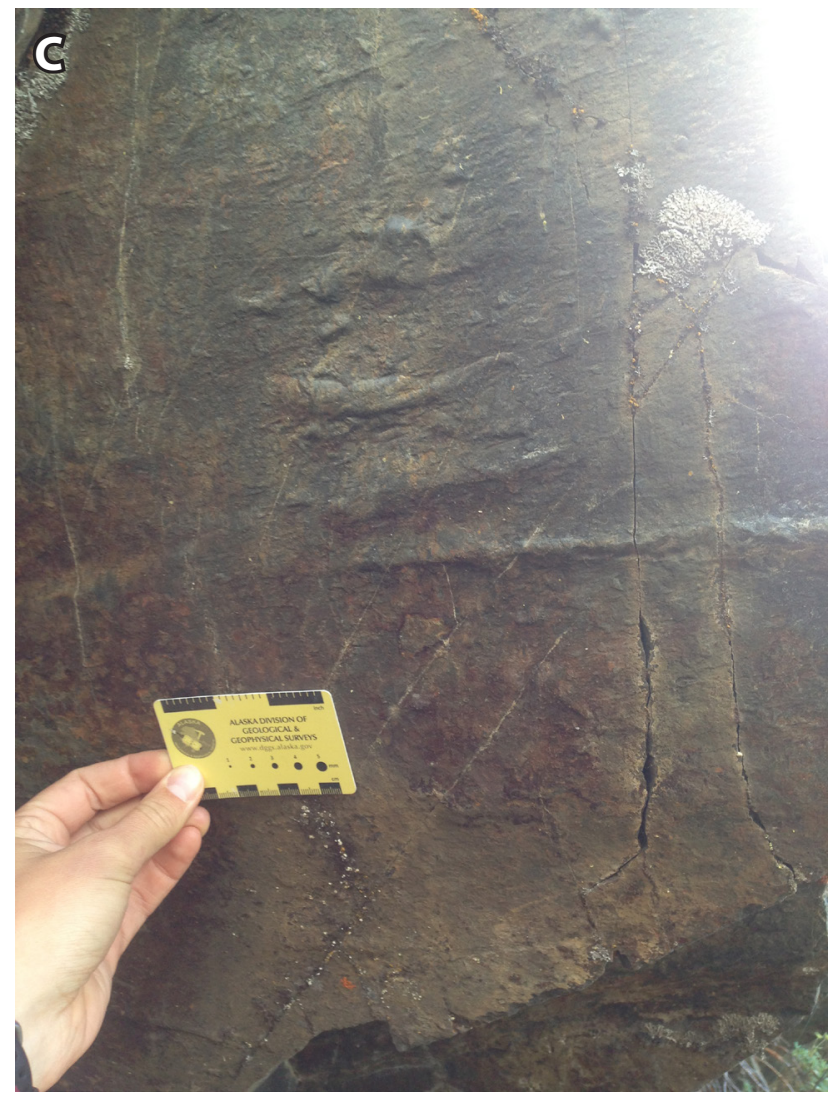

Figure 4. Sedimentary structures from a well indurated siltstone to sandstone in finely bedded, turbiditic Kuskokwim group showing $(\mathbf{A})$ graded bedding (side view; top is up), (B) ) ripples (view from top of bed; station 13KS149A), (C) flute casts and tool marks (view of the bottom side). 
weaknesses such as fold hinges. Many dikes do not have age constraints that could aid in unraveling of the structural story for the region.

\section{Faults, Fractures, and Dikes}

Far-field effects of subduction along the southern margin of Alaska and right-lateral strike-slip faulting along the Denali Fault likely drove faulting in the western Alaska Range. Other authors cite strike-slip displacement from ca. 54 to $24 \mathrm{Ma}$ and regional transpressive shortening characterized the suture since $24 \mathrm{Ma}$ (Ridgeway and others, 2002), accompanied by widespread 30-18 Ma exhumation in response to initial Yakutat microplate collision (Lease and others, 2016). New studies also show that from 12 to 6 Ma uplift and erosion occurred as the crust was advected through the McKinley restraining bend of the Denali Fault, followed by 3.7-2.7 Ma erosion of high-relief areas due to efficient glaciers (Lease and others, 2016).

\section{Kkw: Poles to bedding planes}

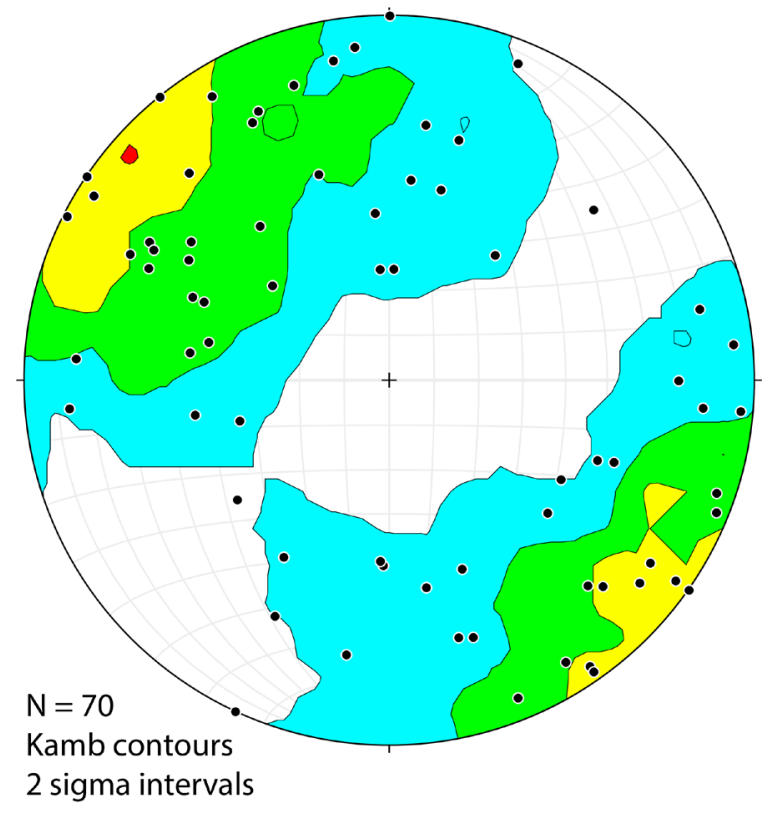

Figure 5. Bedding planes of the Whistler petrofacies of the Kuskokwim Group from the field area showing the northwest-southeast compression of the closing Kahiltna basin. Plotted using Stereonet 10 (Allmendinger and others, 2012; Cardozo and Allmendinger, 2013).
Major fault sets in the western Alaska Range are generally high-angle and trend northwest, northsouth, and north-northeast. During the pulses of magmatism in the Late Cretaceous, emplacement of linear magmatic bodies seems to have been structurally controlled by the orientation of the subduction zone, perpendicular to the original margin of collision. These plutons cut across the suture of the Wrangellia composite terrane with the Farewell terrane.

On the Lime Hills C-1 Quadrangle map, the two distinct fault trends are the west-northweststrike-slip faults and north-south normal faults. The north-south oriented normal faults likely resulted from east-west extension, and pre-date the strike-slip faults. The north-south faults are also likely older as they are not well preserved or observed, and trends can only be seen in the map patterns and geophysical patterns. The west-northwest strike-slip faults are likely left-lateral due to their conjugate nature to the right-lateral east-northeast striking western Denali and Castle Mountain faults and the resulting local east-west compression. Left-lateral strike-slip fault sense was also measured in a few brittle kinematics indicators, and there appears to be apparent offset of units from geophysics and outcrop observations. Little definitive evidence is present, but this structural style and relation to the larger structures in the region is likely found in the map area. Further evidence for the left-lateral faults in this area comes from mineral industry studies of apparent dike offset, about 9 kilometers northeast of the Lime Hills C-1 Quadrangle northeast corner. One study found about 750 meters of left-lateral offset across the Timber Creek Fault, next to the Estelle claims (Cody Pink, unpub. data, 2011). Some young dikes from Eocene-Miocene volcanism were also found intruding these weaknesses.

Viewed in stereonet, the few plotted measurements define four main visible fault trends: two east-northeast striking that dip about 60 degrees each way (south-southeast and north-northwest) and two west-northwest striking also dipping about 60 degrees each way (north-northeast and south-southwest) (fig. 7). Both trends have an apparent conjugate pair. The 

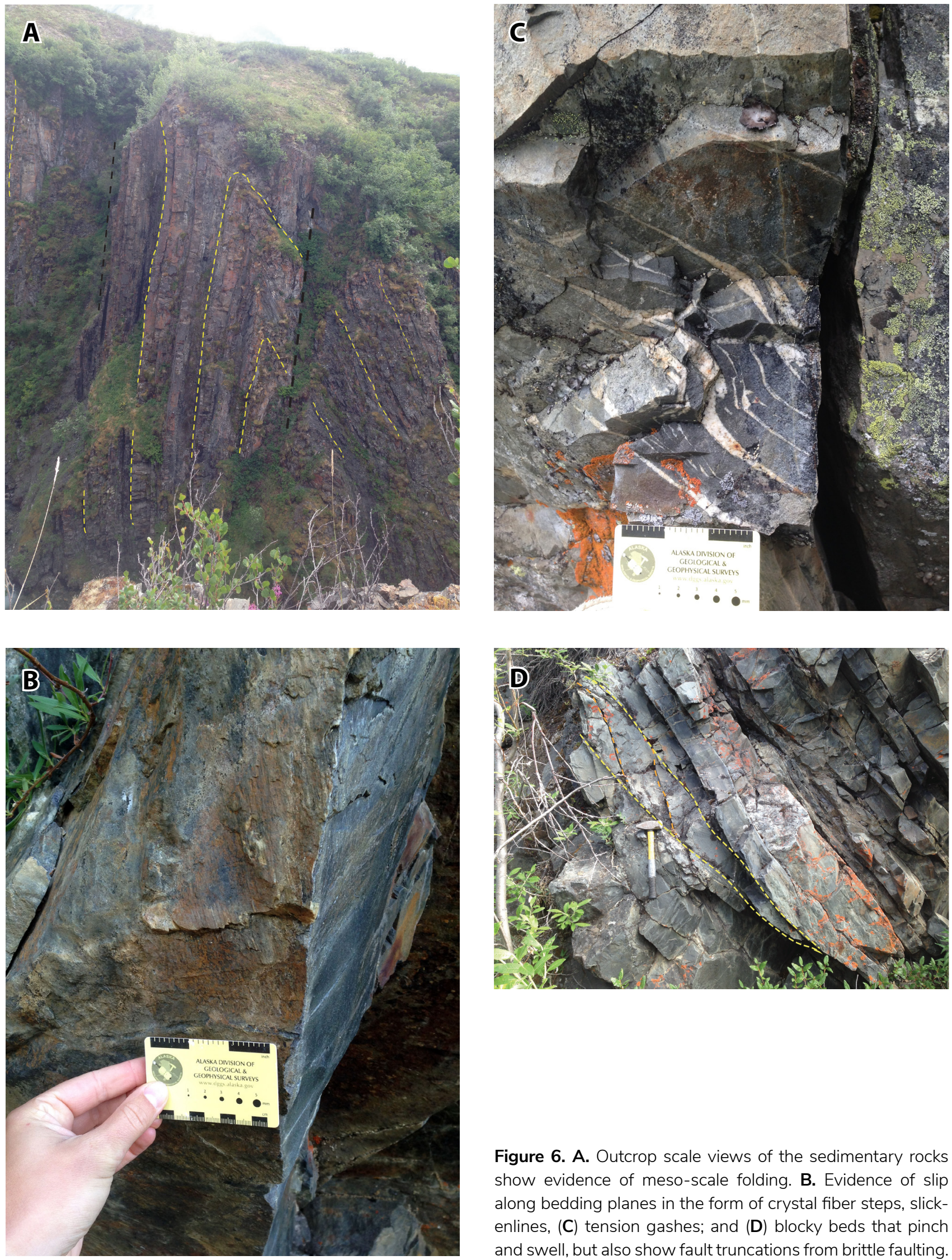

Figure 6. A. Outcrop scale views of the sedimentary rocks show evidence of meso-scale folding. B. Evidence of slip along bedding planes in the form of crystal fiber steps, slickenlines, (C) tension gashes; and (D) blocky beds that pinch and swell, but also show fault truncations from brittle faulting. 
A
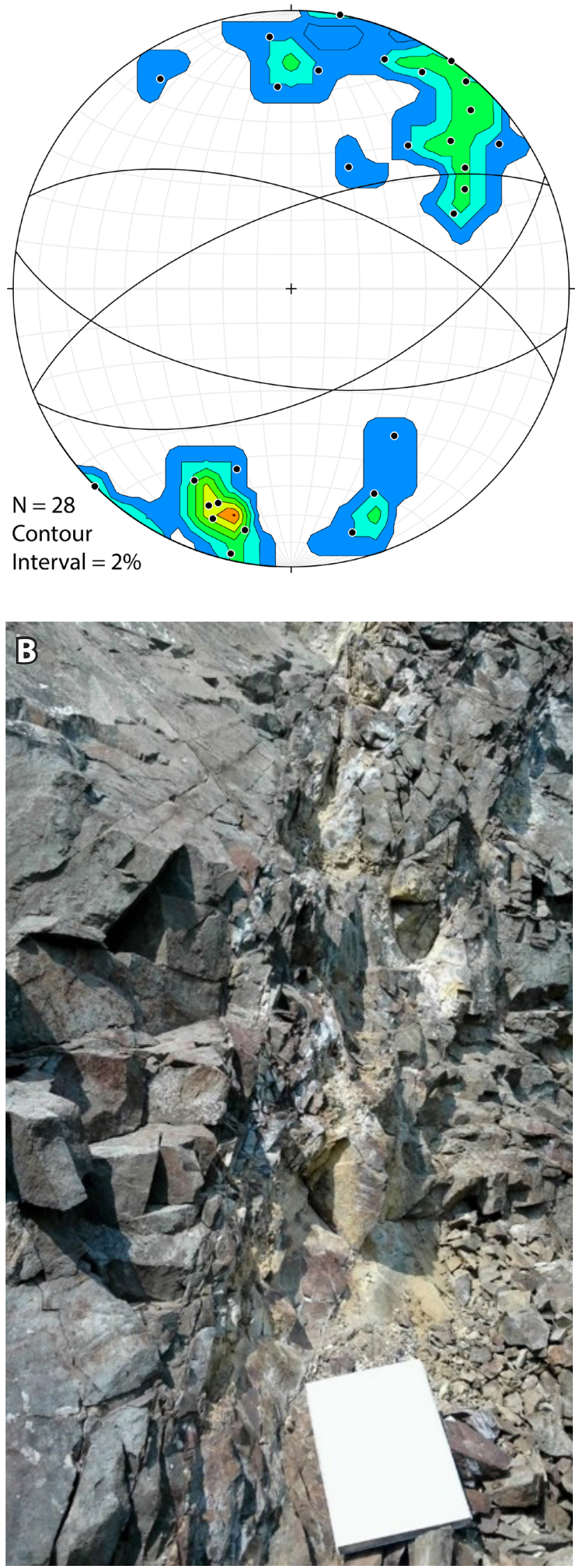

Figure 7. A. Planes and poles to planes of mapped faults and fractures in the field area showing two main trends: The northeast-southwest striking planes with a dip around 60 , and the northwest-southeast striking planes with a dip around 60; both have an apparent conjugate pair. Plotted using Stereonet 10 (Allmendinger and others, 2012; Cardozo and Allmendinger, 2013). B, C. High angle brittle faulting cutting mineralized South Fork pluton at station 13ET007A: Relatively high angle brittle fault in gabbro. Observed down in the valley bottom in a creek wall. The damage zone is $30-\mathrm{cm}$-thick with gouge seams and calcite veining. Striking 178 , dipping 66 to the southwest and lacking convincing kinematics. Map board for scale is approximately 9" by 12 " and view is generally northward.

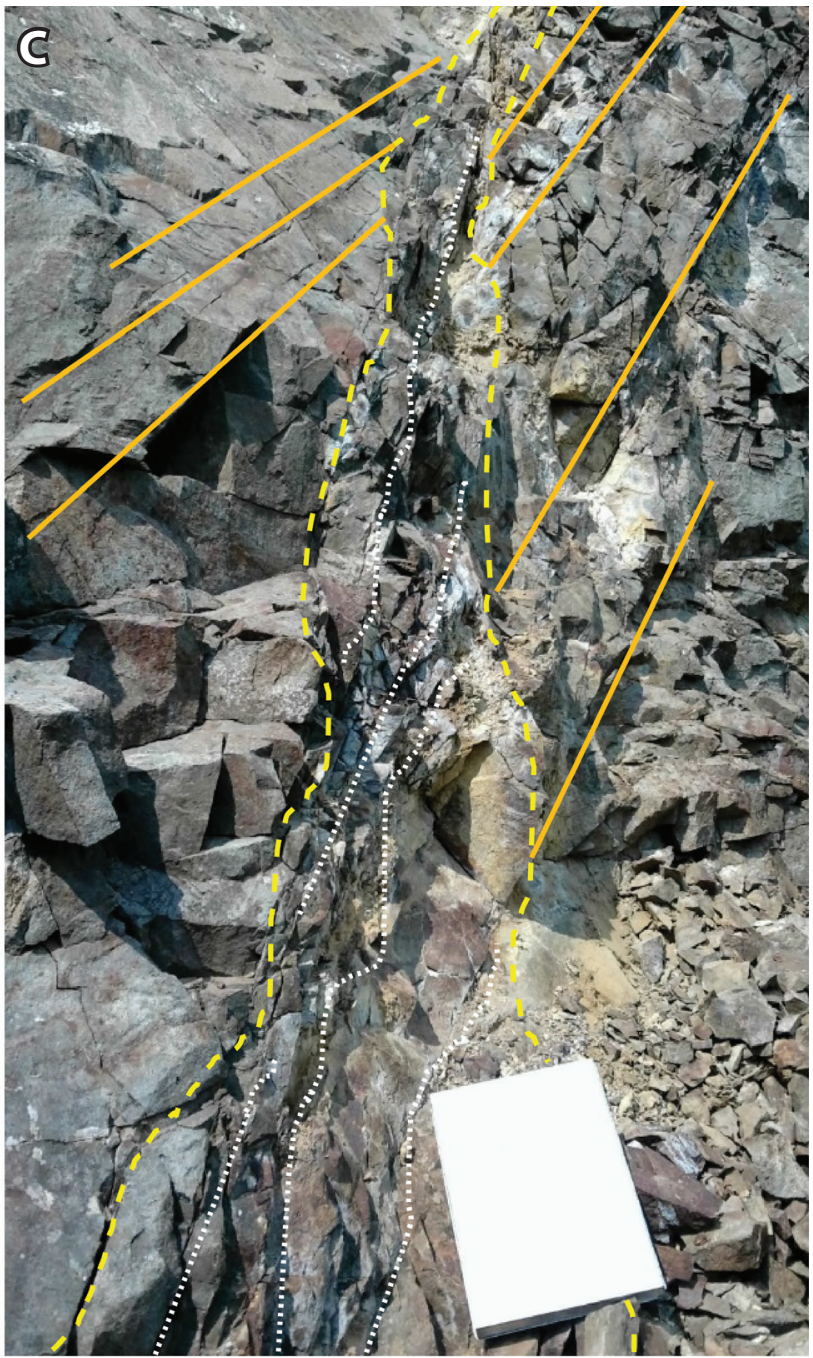


major map fault patterns trend west-northwest and are more commonly seen offsetting units either as normal faults or possibly strike-slip faults. Apparent offset of Paleogene to Neogene dikes may appear to be strike-slip fault sense, but without definitive fault sense indicators these faults could have normal or oblique fault senses (combining both fault senses). Sense of displacement on brittle faults was sometimes observed, but with little to no confidence. A much larger brittle fault study including a large data set of brittle indicators is necessary for higher confidence. The left-lateral sense of fault displacement is tenuous, as many of the fault surfaces are not visible, have conflicting sense of shear, or lack confident marker beds or offset dikes. Further analysis was outside the scope of this map project.

Many of the fractures, faults, and slickenlines measured were on brittle faults, and the preservation of these features led us to interpret them as younger than Paleocene faulting since they cut Paleocene plutons or dikes. When faults cut the Eocene Merrill Pass granite (where it is confidently identified), or dikes that are likely younger than Eocene they are interpreted as Eocene and younger, possibly related to young dikes dated at $-10 \mathrm{Ma}$ in the Copper Joe region. A set of brittle, late-stage faults are interpreted as post-mineralization, with northwest-trending strikes, high-angle dips, and strike-slip fault sense. These faults generally appear to have a left-lateral offset of dikes but could also be a product of normal motion or oblique motion that displays an apparent horizontal displacement from vertical displacement of dipping contacts. However, the strike of these northwest faults is similar to the interpreted left-lateral Timber Creek Fault in the Mount Estelle pluton only a few kilometers east of the northeast corner of the map area (see economic geology section).

The story is complicated by many generations of dikes and multiple episodes of faulting throughout the Cenozoic, with the earliest structures likely rotated on later structures during regional oroclinal bending. The broader region is bracketed by the east-northeast striking Castle Mountain and Denali right-lateral strike-slip faults (fig. 1). Evidence for extension between these faults is recorded by tensional dikes, veins, and major west-northwest strike-slip faults. A clustering of dike measurements from the field area have an average strike of approximately 75 degrees and steep dips (fig. 8A). A clustering of vein measurements from the field have similar east-northeast strikes (approximately 60-70 degrees) and steep dips (fig. 8B). These orientations suggest the regional extension direction was approximately north-south to northwest-southeast during dike and vein formation. Scatter in the data may be due to local or regional block rotation or changes in the stress field over time due to oroclinal bending in south-central Alaska.

\section{Regional Magmatic Periods}

Across the western Alaska Range, mid Cretaceous to Oligocene intrusive rocks document at least five magmatic flare-up episodes from 102-28 Ma, lasting $\sim 10$ m.y. each (Todd and Jones, 2017), and demonstrate a diversity of tectonic events and crustal accretion at the evolving continental margin. Igneous rocks in the Lime Hills C-1 Quadrangle fall into the second through fourth magmatic episodes as displayed in a summary of the relevant geochronology for the area in table 2. The first pulse of plutonism intruded the western Alaska Range during a period of shortening and inboard migration of the volcanic arc during and after the closure of the Kahiltna basin from $-100-76 \mathrm{Ma}$. This stage included the well-known $\sim 90 \mathrm{Ma}$ Pebble $\mathrm{Au}-\mathrm{Cu}-$ Mo porphyry deposit. Intrusions of this age are not observed within the Lime Hills C-1 Quadrangle. Deformation of the basin sediments continued after deposition and is likely constrained by undeformed plutons (dated at 80-76 Ma) that cross-cut folds in the Kahiltna basin sediments elsewhere in the western Alaska Range (Todd and Jones, 2017).

Following basin closure around $76 \mathrm{Ma}$, the next magmatic flare-up occurred from 72-67 Ma (Late Cretaceous) across this suture zone (Todd and Jones, 2017), including the South Fork gabbro and monzogranite intrusions in the map area. 


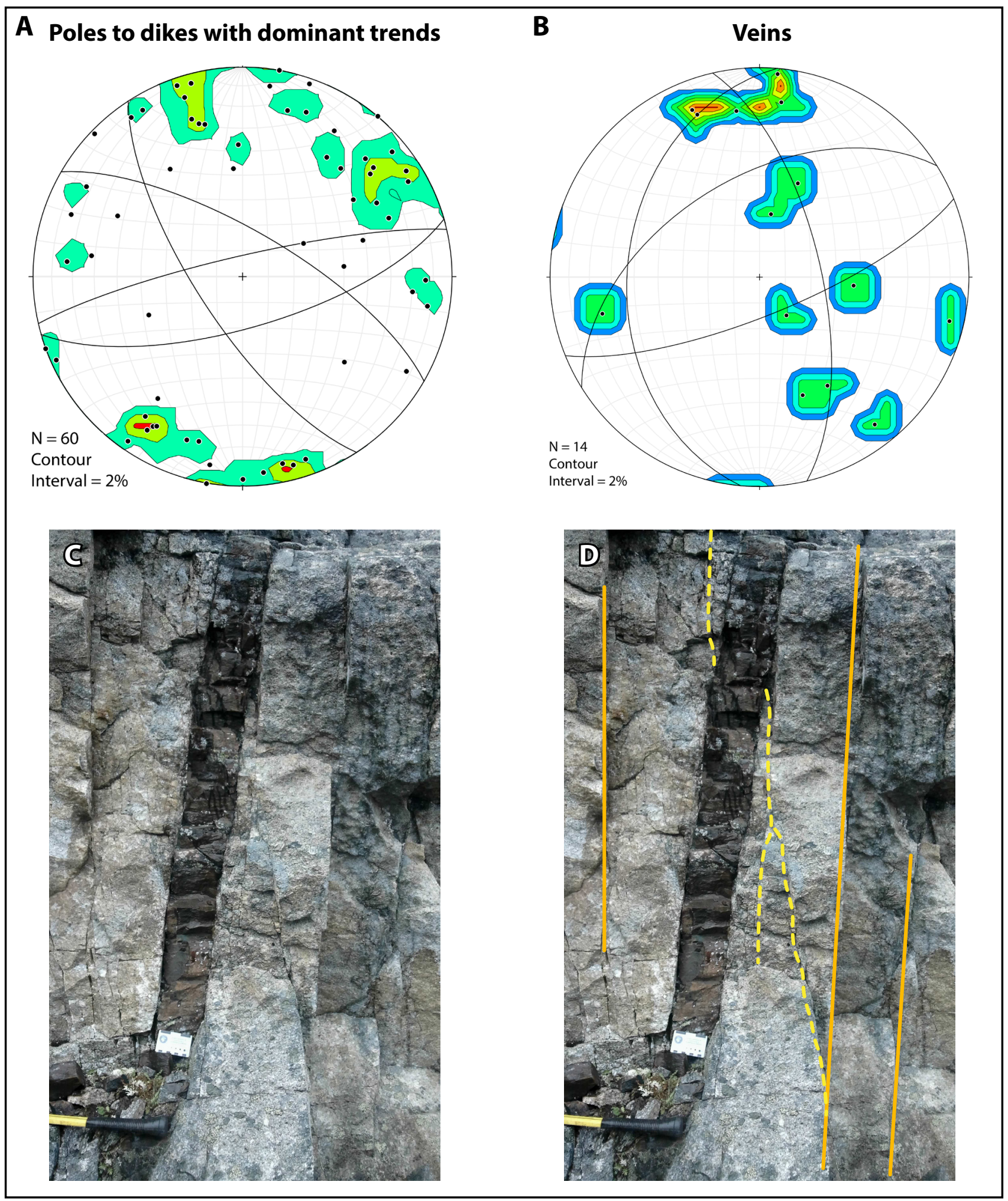

Figure 8. A. Poles to planes of all the dikes in the field area showing four main clusters: the northwest-southeast striking near-vertical dikes, and northeast-southwest near-vertical dikes. Planes plotted are the dominant trends of these dike wall planes. Major conjugate dike trends: SE: 142, 70 (10) NW: 300, 72 (9). NE: 074, 70 (11), SW: 257,82 (6). B. Poles to planes of measured veins in the field area. Plotted are two representative trends for veins as planes: The northeast-southwest striking planes with a dip around 60, and the north-south striking planes with a dip around 60; both have an apparent conjugate pair. Both plotted using Stereonet 10 (Allmendinger and others, 2012; Cardozo and Allmendinger, 2013). C, D. A near vertical lamprophyre dike (northwest striking) within the Mount Estelle pluton with thin distal tourmaline and magnetite veins. The pluton also contains many aplite dikes. 


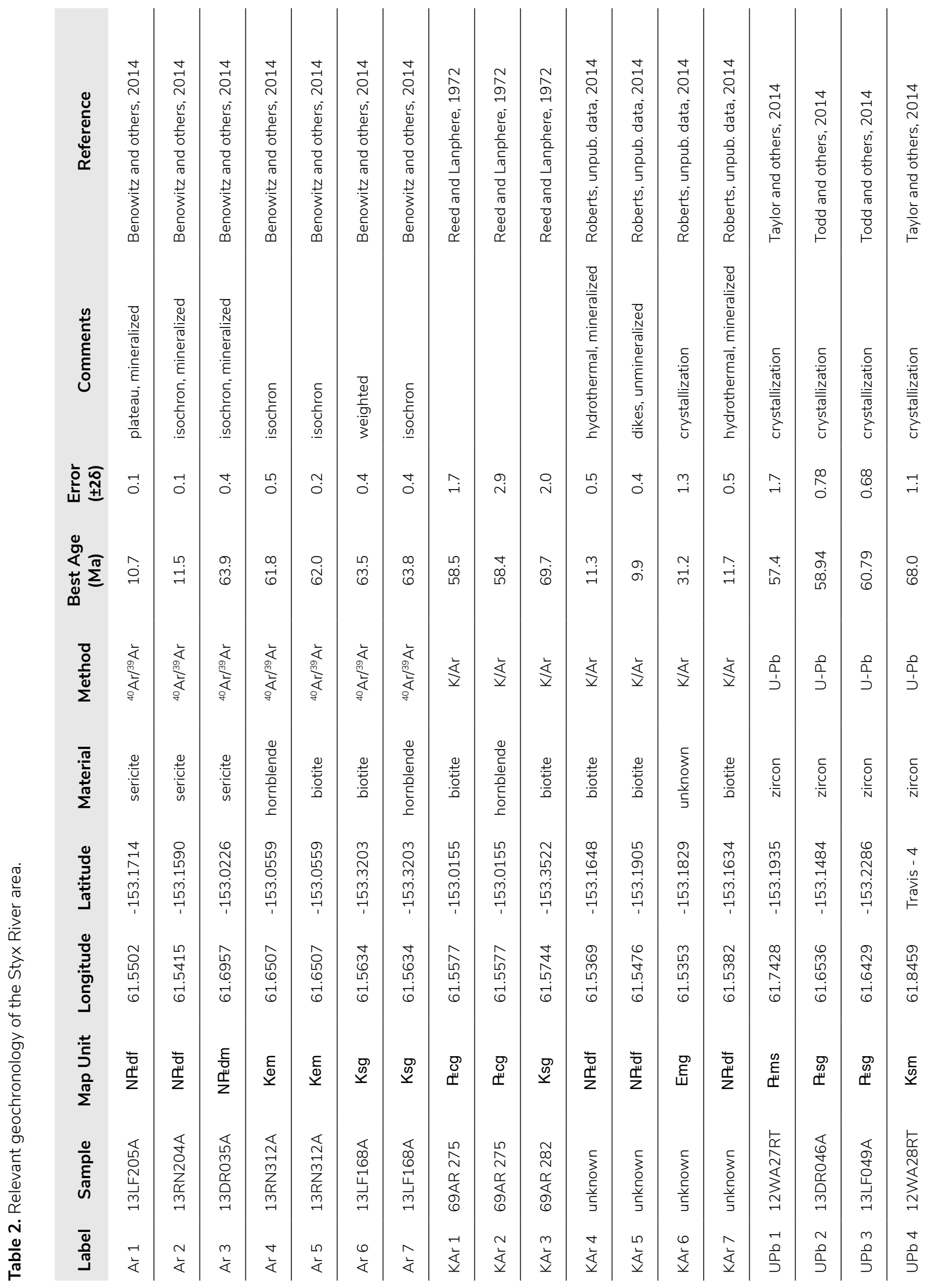


The next magmatism from 63-56 Ma (Paleocene) accompanied ridge subduction and ended as the collisional thickening and melting stage terminated, causing a magmatic hiatus of about 10 m.y. (Bradley and others, 2003; Todd and Jones, 2017). The Mount Estelle, Crystal Creek, Styx River, and McKinley Sequence plutons in the map area were intruded during this episode. Tectonic reorganization likely reinvigorated the volcanic arc melting and produced the large plutons and associated rhyodacite deposits of the fourth phase from about 42-32 Ma (Todd and Jones, 2017), including the Merrill Pass Granite. Oligocene 32-22 Ma flare-up in the fifth stage of magmatism occurred farther west of the map area and included peralkaline plutons and associated rare earth element (REE) mineralization (Todd and others, 2017). A final period of magmatism as dikes and small stocks, along with associated hydrothermal mineralization, occurred between 10 and $12 \mathrm{Ma}$, especially around the Copper Joe prospect in the southern Lime Hills C-1 Quadrangle (Roberts, 2015).

\section{Petrology and Geochemistry of Plutonic and Volcanic Rocks}

Major- and trace-element compositions are reported in Sicard and others (2014a) for over 600 samples in the Lime Hills C-1 Quadrangle and surrounding area. This report presents plots and subsequent interpretations from selected samples. The uncalibrated broad lens X-Ray Fluorescence (XRF) data (Sicard, 2013) were excluded from these plots in favor of the whole rock, major oxide ICP-MS analyses (Sicard, 2014b) because they were collected by an outside lab with blind standards and QA/QC procedures.

The geochemical plots help delineate the tectonic setting of the igneous rocks, correlate unknown units to known ones, and refine unit boundaries (fig. 9). The gray shaded Estelle prospect and green shaded Terra prospect polygons on these diagrams are generalized from proprietary geochemistry data of Millrock Resources Inc. and WestMountain Gold Inc., respectively, for compar- ison data from this study. Trace-element compositions illustrate slight distinctions between units and provide another tool to highlight differences between felsic plutons on the bivariate diagrams since the majority of the plutonic rocks are granitic, with over 70 percent $\mathrm{SiO}_{2}$ (fig. 10). The igneous rocks as a whole vary from low silica to very high silica content, including some with silica alteration that contain up to 90 weight percent $\mathrm{SiO}_{2}$.

The overarching trends in the geochemistry rely on the USGS Western Alaska Range Project (WARP) research, which allow our data to fit into regional models. When results of trace elements, isotope geochemistry, and geochronology are combined there is evidence for metaluminous rocks (fig. 11) with typical volcanic arc geochemical signatures (fig. 9), indicating short residence times and limited fractional crystallization in the Late Cretaceous. Contrastingly, plutons emplaced in the Paleocene are widely distributed, highly evolved, and have evidence of crustal assimilation.

\section{Late Cretaceous Plutons}

The oldest plutons in the Lime Hills C-1 Quadrangle are the Late Cretaceous Mount Estelle monzogranite (unit Kem; -68 Ma) and the South Fork gabbro (unit Ksg; $-68 \mathrm{Ma}$ ). The textures of these plutons are generally hypidiomorphic granular to equigranular rather than porphyritic (fig. 12). These plutons range from gabbro to granodiorite and predominantly have an arc affinity (figs. $9 \mathrm{~A}$ and B). Mount Estelle monzogranite samples have $\mathrm{SiO}_{2}$ content of -65 weight percent whereas South Fork gabbro to granodiorite ranges from 45 to 60 weight percent $\mathrm{SiO}_{2}$ (figs. 9A-C). Geochemical plots from this study also show that the Cretaceous rocks are magnesian and metaluminous (figs. 11A and C). The South Fork pluton has very little to no Eu anomaly (fig. 10I), with possible plagioclase-fractionation suppression. The South Fork gabbro is the major phase of this pluton, but a monzogranite "stock" identified by Gamble and others (2013) is mapped within the larger pluton that gives the pluton a spread in data points. 

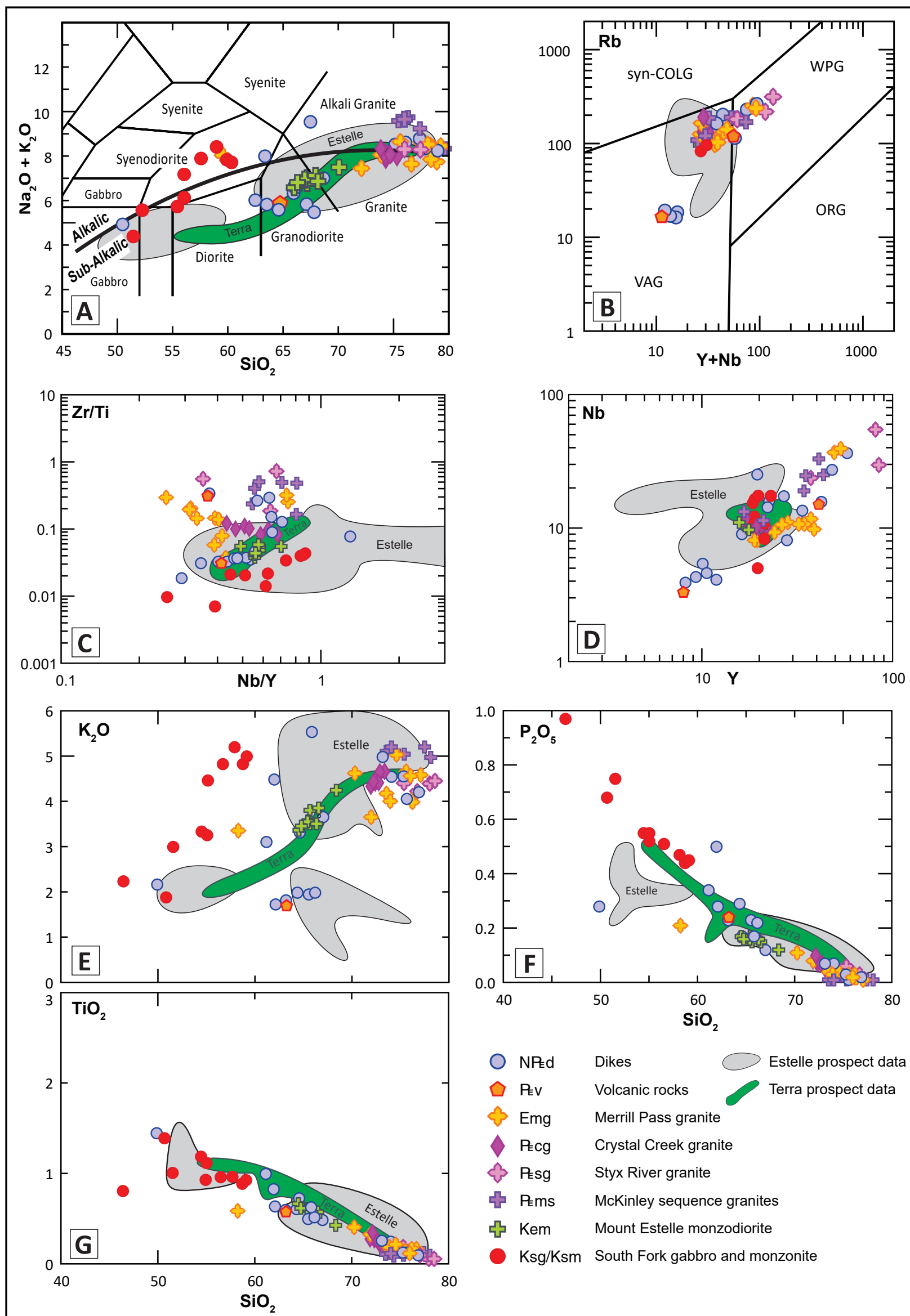
Previously mapped "Undifferentiated" plutonic rocks (Gamble and others, 2013) were reclassified as South Fork pluton due to their identical REE pattern (fig. 10; black outlined red circles in the South Fork plot were originally part of the "Undifferentiated" unit).

Samples collected during DGGS field work in the Lime Hills C-1 Quadrangle have $-62 \mathrm{Ma}$ ${ }^{40} \mathrm{Ar} /{ }^{39} \mathrm{Ar}$ ages from biotite and hornblende from the Mount Estelle pluton and $-64 \mathrm{Ma}{ }^{40} \mathrm{Ar} /{ }^{39} \mathrm{Ar}$ ages from biotite and hornblende from the South Fork monzogranite (Benowitz and others, 2014). $\mathrm{U}-\mathrm{Pb}$ zircon ages from outside the map area range from 67 to $71 \mathrm{Ma}$ (Taylor and others, 2014). We assign a Late Cretaceous age to both plutons based on the $\mathrm{U}-\mathrm{Pb}$ ages and interpret the younger ${ }^{40} \mathrm{Ar} /{ }^{39} \mathrm{Ar}$ ages to record slow cooling or post-emplacement alteration ages.

\section{Paleocene Plutons}

Paleocene intrusions in the Lime Hills C-1 Quadrangle include the Crystal Creek granite ( $-60 \mathrm{Ma})$, Styx River granite $(-60 \mathrm{Ma})$, and the McKinley sequence granites ( $-58 \mathrm{Ma})$. The Styx River granite was split out from the Eocene Merrill Pass granite $(-35-40 \mathrm{Ma})$ due to new $(-60 \mathrm{Ma})$ $\mathrm{U}-\mathrm{Pb}$ dates (table 2). Paleocene (and Eocene) granites are generally much more fractionated than Late Cretaceous plutons (figs. $9 \mathrm{E}-\mathrm{G}$ ) (Todd and Jones, 2017; Sicard and others, 2014a, 2014b). These peraluminous and alkaline granites imply highly differentiated, shallow magma chambers. This is also suggested by miarolitic cavities (fig. 13A), and the porphyritic to seriate textures of the younger intrusive rocks in the Lime Hills C-1 Quadrangle. McKinley sequence granites are distinguished from other high silica granitoids in the region by their lower $\mathrm{Fe}^{*}$ composition $\left(\mathrm{FeO}_{\text {total }} /\left[\mathrm{FeO}_{\text {total }}+\mathrm{MgO}\right]\right.$; fig. 11B). These plutons lie on the same fractionation trend, suggesting similar petrogenesis.

Styx River and Crystal Creek granites (as well as the Eocene Merrill Pass granite) are almost indistinguishable from each other using major elements, however, Crystal Creek has slightly higher MALI composition $\left(\mathrm{Na}_{2} \mathrm{O}+\mathrm{K}_{2} \mathrm{O}-\mathrm{CaO}\right)$ putting it in a much tighter grouping of alkali-calcic granitoids whereas the majority of the Styx River granite is characteristically calc-alkalic (fig. 11). McKinley sequence granites are more similar to the Cretaceous pluton trace element signatures. Most of the plutons are "Cordilleran type batholiths" or "volcanic arc granitoids" and some are "A-type pluton" or extension related granitoids (fig. 11: Frost and others, 2001; Frost and Frost, 2008). The Crystal Creek, and Styx River plutons are highly evolved with strong europium (Eu) anomalies (fig. 10). The Crystal Creek granite has a more consistent and stronger Eu anomaly than the $\mathrm{Eu}$, $\mathrm{Sr}$, and Y patterns of the Styx River granite, which suggests fractional crystallization and assimilation were occurring more in the Crystal Creek granite. Two U-Pb zircon ages from the Styx River pluton were approximately $3 \mathrm{~m}$.y. apart, but within error (58.94 $\pm 0.78 \mathrm{Ma}$ sample 13DR046A and 60.79 $\pm 0.68 \mathrm{Ma}$ sample 13LF049A; Todd and others, 2017). One of these had a distinctly different REE composition than the rest of the Styx River pluton, more like felsic dike signatures. This composition is difficult to explain by fractional crystallization alone (fig. 10E-D, sample 13DR046A outlined in red); it likely represents a leucocratic phase of the Styx River pluton with more crustal input. The McKinley Sequence granites are not well defined in this area and were poorly sampled, so we retained the previous nomenclature (Gamble and others,

Figure 9, previous page. Geochemical plots of igneous rocks. All major elements are normalized on an anhydrous basis to 100. Granite discrimination diagrams are based on Pearce and others (1984). A. TAS: Total alkalis versus silica for plutonic rocks (Wilson 1989); (B) Rb versus $\mathrm{Y}+\mathrm{Nb}$; (C) $\mathrm{Zr} / \mathrm{Ti}$ versus Nb/Y; (D) Nb versus Y; (E) $\mathrm{K}_{2} \mathrm{O}$ versus $\mathrm{SiO}_{2}$; (F) $\mathrm{P}_{2} \mathrm{O}_{5}$ versus $\mathrm{SiO}$; and (G) $\mathrm{TiO}_{2}$ versus $\mathrm{SiO}_{2}$. All data are from samples analyzed for major oxide composition and trace elements using ICP-MS (Sicard and others, 2013). The green shaded area represents proprietary geochemical data of diorites from the Terra project of WestMountain Gold Inc. (fig. 1; WestMountain Inc, written commun., 2013). The gray shaded area represents proprietary Mount Estelle pluton geochemistry analyzed by Millrock Resources Inc. in 2012 and 2013 (Millrock Resources Inc., written commun., 2013). 


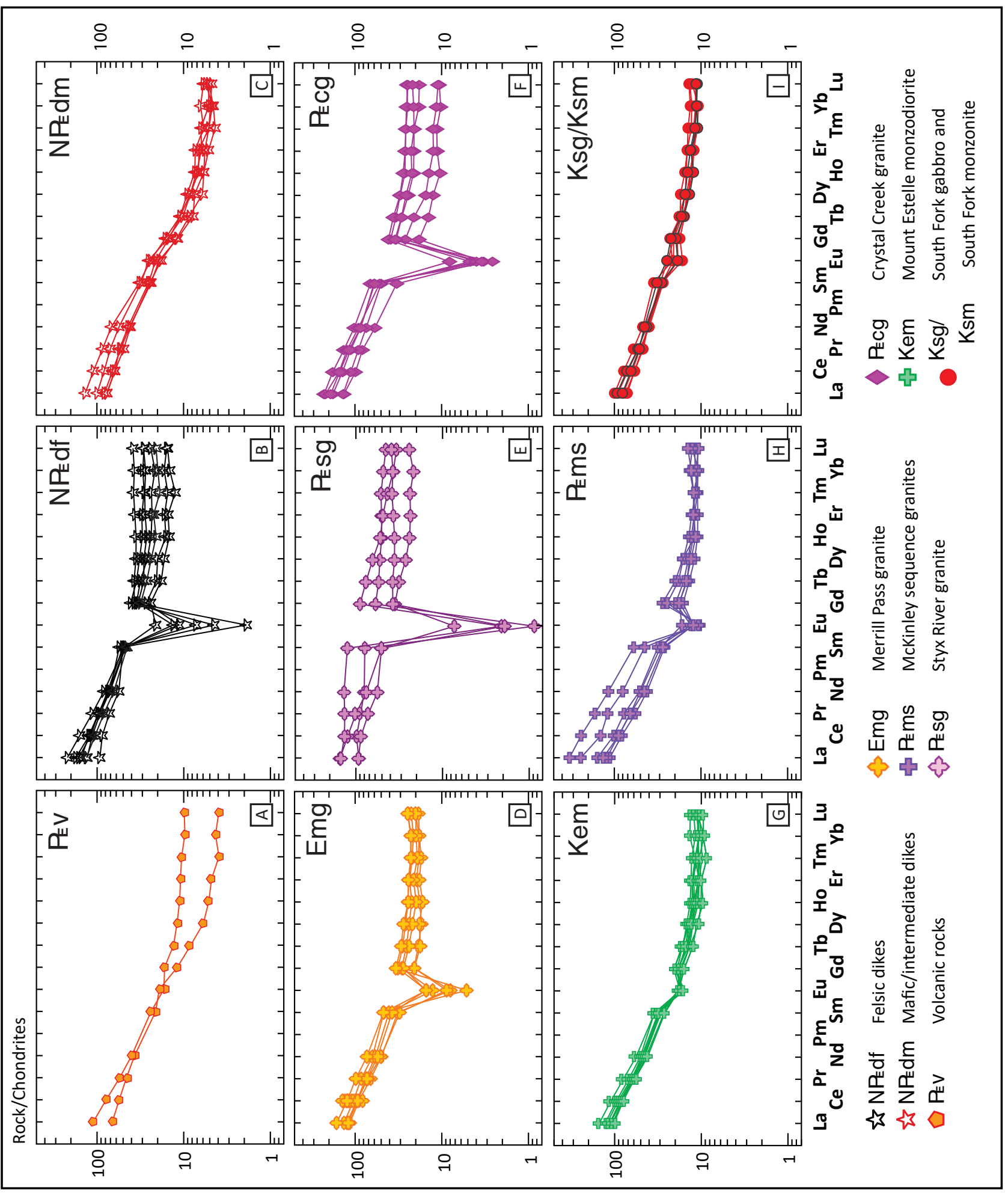

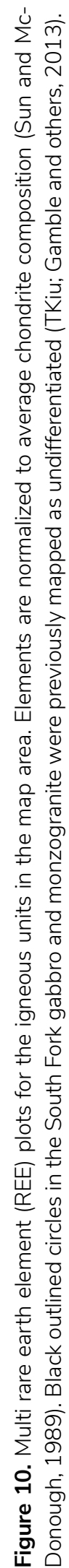



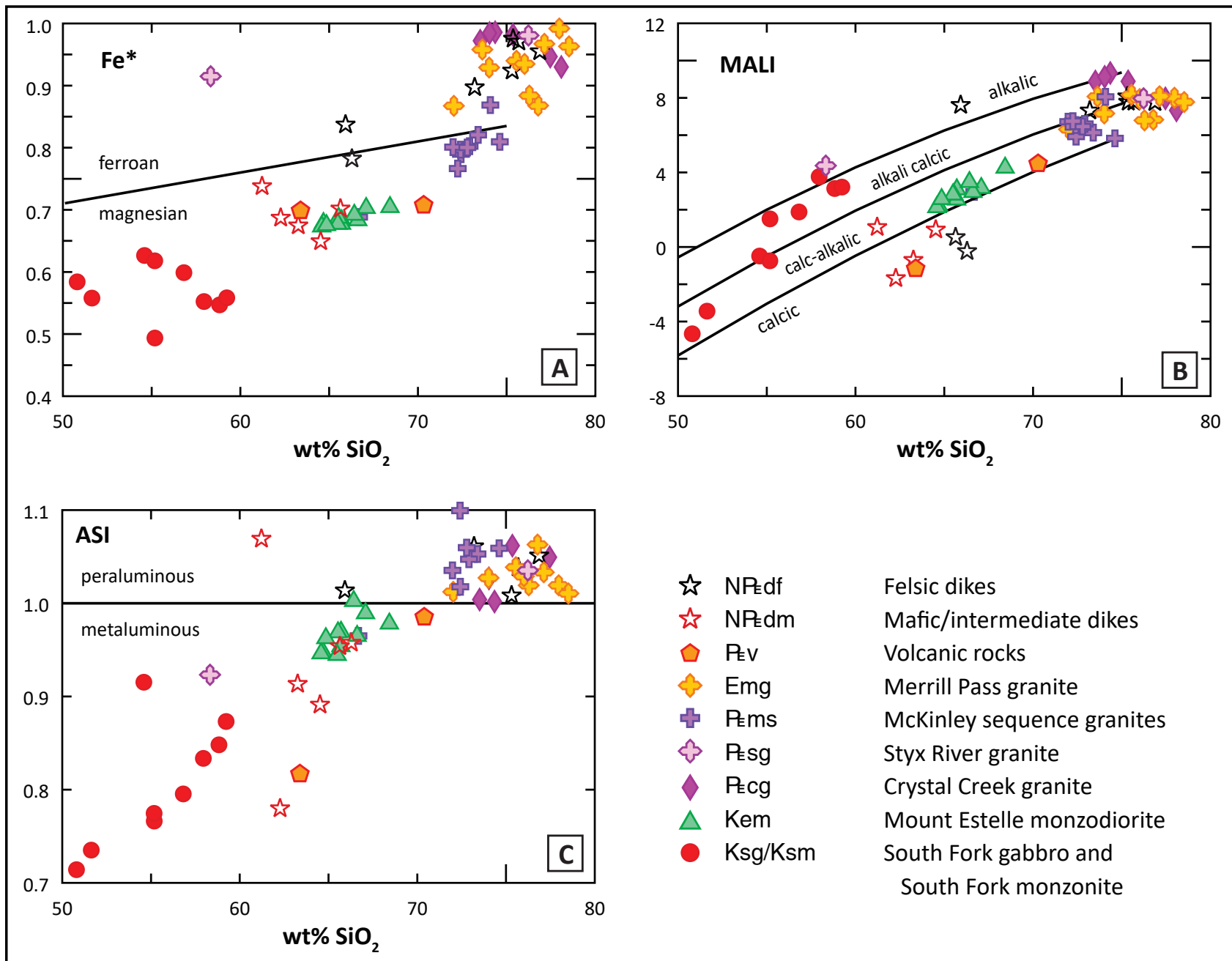

Figure 11. Classification of granitoids (Frost and others, 2001; Frost and Frost, 2008). A. Fe-number $\left(\mathrm{Fe}^{*}=\mathrm{FeO}_{\text {total }} /\left[\mathrm{FeO}_{\text {total }}\right.\right.$ $+\mathrm{MgO}])$. B. Modified alkali-lime index (MALI $\left.=\mathrm{Na}_{2} \mathrm{O}+\mathrm{K}_{2} \mathrm{O}-\mathrm{CaO}\right)$. C. Aluminum Saturation Index (ASI = AI / [Ca $-1.67 \mathrm{P}+$ $\mathrm{Na}+\mathrm{K}])$. The data plotted on the diagram were recalculated to 100 percent anhydrous with $\mathrm{Fe}$ split into $\mathrm{FeO}$ and $\mathrm{Fe}{ }_{2} \mathrm{O}_{3}(\mathrm{Le}$ Bas and others, 1986)

2013; Lanphere and Reed, 1985) due to the lack of $\mathrm{U}-\mathrm{Pb}$ dates and detailed data from which to base new conclusions. The McKinley sequence granite warrants more study in context of ongoing work redefining the McKinley sequence (Hung, 2008; Hung and others, 2007; Regan and others, 2019).

\section{Miocene to Eocene Intrusions}

The Eocene Merrill Pass granite (Emg) was originally subdivided on the map into two separate phases with strongly contrasting magnetic susceptibilities apparent in airborne magnetic data (Burns and others, 2019; Sicard and others, 2014b). However, this magnetic differentiation was not supported by a geochemical difference. Newly acquired U-Pb zircon ages returned Paleocene rather than Eocene ages, suggesting that the younger Eocene Merrill Pass granite had intruded into an older, geochemically similar Paleocene granite. We divided and renamed the Paleocene Styx River granite with complex, irregular, and uncertain boundaries from field observations, magnetic signatures, and textural rock unit descriptions, but lacking much age and detailed geochemical results (fig. 14A). More work is needed to specify the geochemical and textural differences and spatially check the interpolated map contacts. Field observations also revealed inclusions at the contact between the Styx River granite and 


\section{A Mount Estelle Monzodiorite (Kem)}

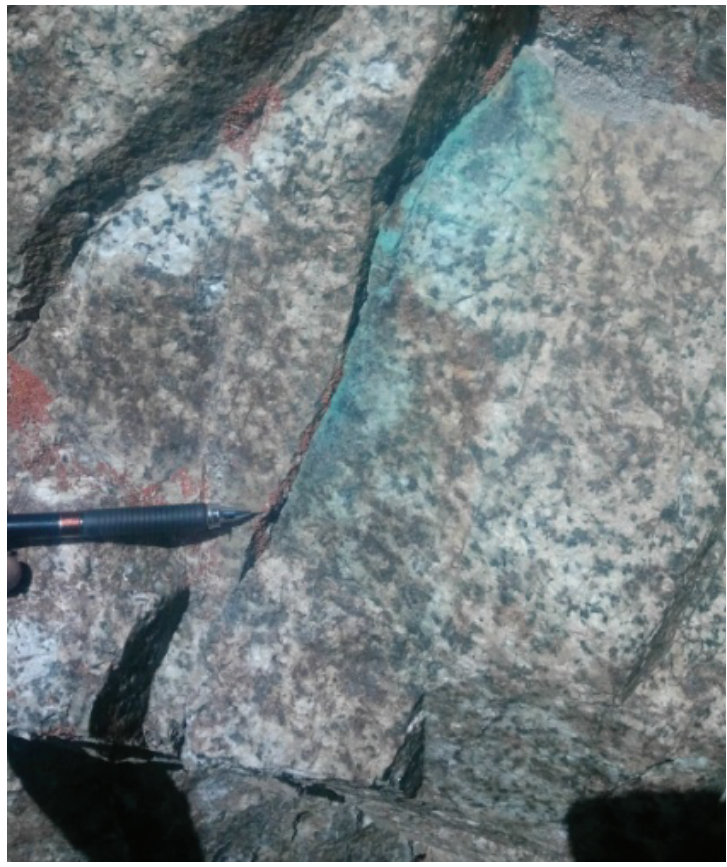

\section{B South Fork Gabbro (Ksg)}

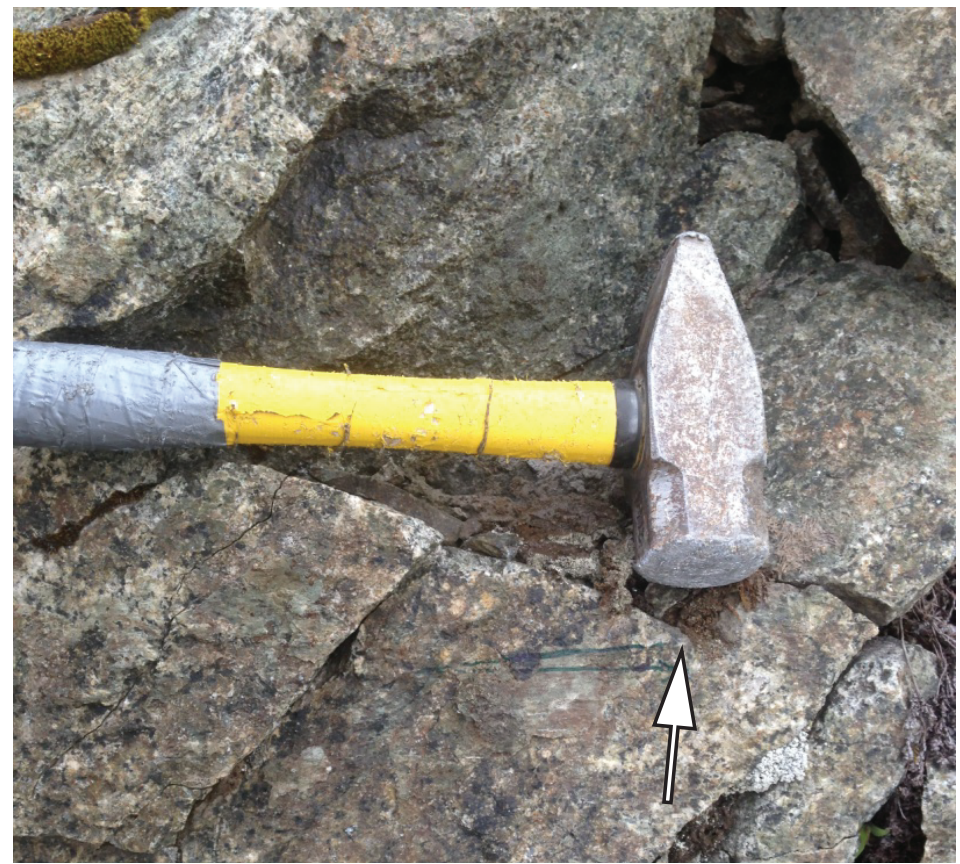

Figure 12. Mount Estelle pluton (Kem) displaying (A) typical textures of the biotite-hornblende monzodiorite, with malachite staining near a vein. Other veins in the pluton contain quartz, arsenopyrite, chalcopyrite, and magnetite; (B) a typical hornblendepyroxene-biotite granodiorite in the South Fork Gabbro, a multiphase pluton. Textures are fine- to medium-grained, seriate, and hypidiomorphic-granular. The green pen line is over a mineral streak on a small brittle fracture (white arrow).

A

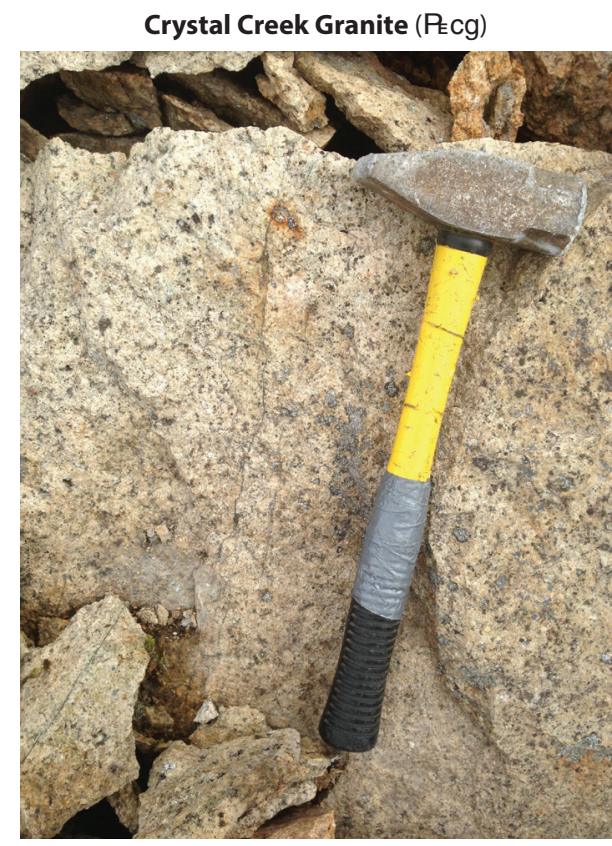

B

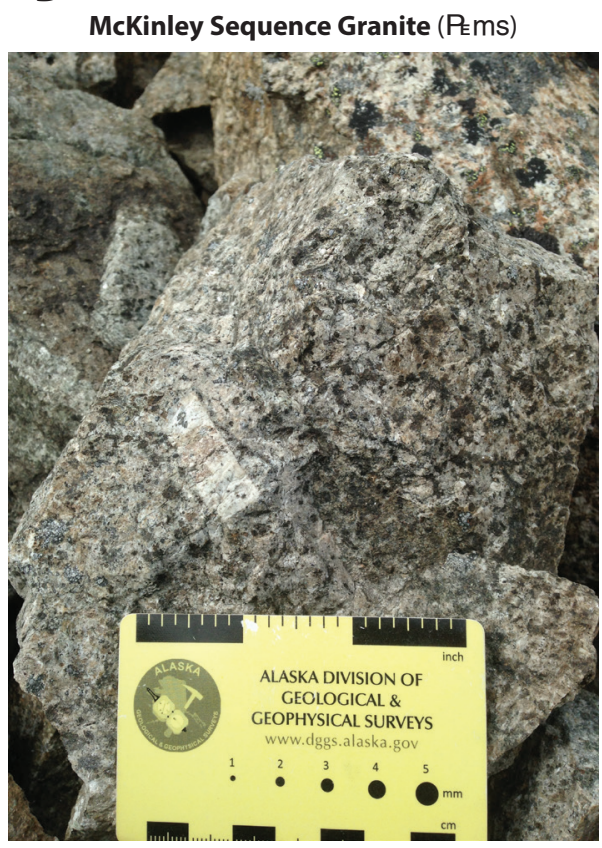

C McKinley SequenceGranite (PEms)

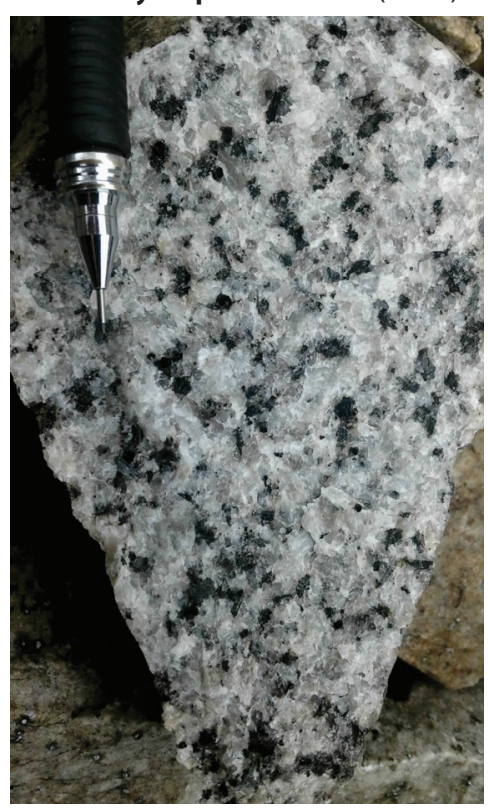

Figure 13. The Crystal Creek granite (A) displays a typical medium to coarse-grained, seriate to porphyritic, hypidiomorphic texture, with miarolitic cavities, biotite and hornblende altered to chlorite, $<1 \mathrm{~mm}$ chlorite veinlets, and pervasive weathering. Photos of the McKinley suite granites ( $\mathbf{E} \mathbf{m s})$ display both (B) a megacrystic texture ( 4-cm-long feldspar megacryst), and (C) hypidiomorphic granular biotite granite. 

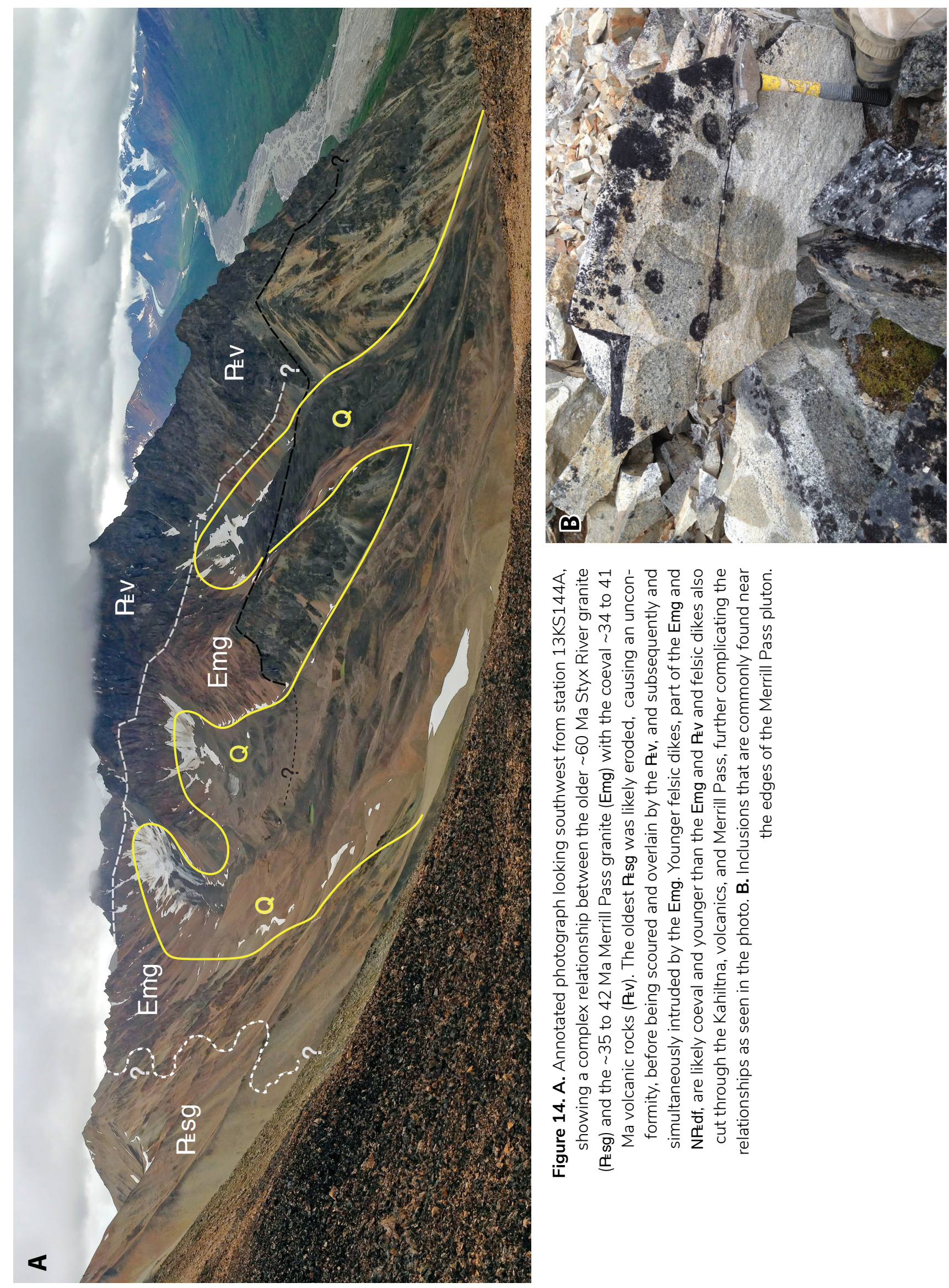

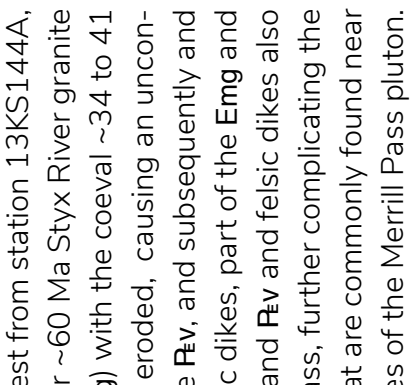

崩

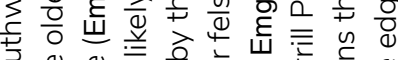

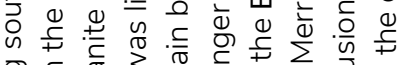

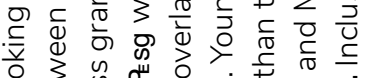

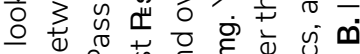

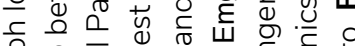

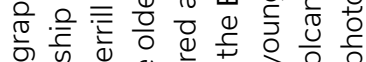

का

芩

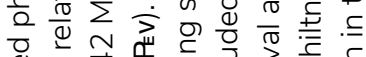

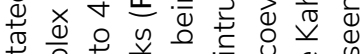

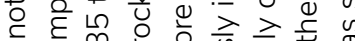

定宁?

४

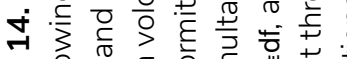

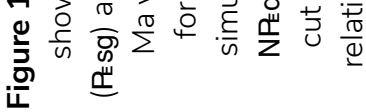


the Merrill Pass granite, implying complexity (fig. 14B). The markedly older age of the Styx River pluton (-60 Ma U-Pb, Todd and others, 2017) separates this from the younger Merrill Pass pluton (35-42 Ma Reed and Lanphere, 1972; Gamble and others, 2013), coeval with volcanic rocks of $-34-41$ Ma (fig. 14A)(Reed and Lanphere, 1972). A 31.2 $\mathrm{Ma}$ K/Ar date from the Copper Joe area (Roberts, 2014 ) is younger than other ages reported for the unit and the lack of information on what material was dated makes this age unreliable for interpretation. Intruding the Eocene Merrill Pass pluton is a Miocene phase of porphyritic granite associated with the Copper Joe prospect that is also cut by mineralized felsic dikes of Miocene age (10-12 Ma; Benowitz and others, 2014; Roberts, 2014). More data is needed to determine whether this young porphyry mineralization is a Miocene porphyry system with a significant mineralized dike swarm. It is possible that this young system took advantage of the weak intersection of northwest-trending strike-slip faults and north-south-trending faults.

\section{Dikes of Neogene to Paleogene Age}

The REE compositions of dikes (fig. 10B and C) highlight composition, with mafic to intermediate dikes (NPEdm) generally displaying low heavy rare earth element (HREE) concentrations, and felsic dikes (NPdf) generally displaying high HREE concentrations (fig. $10 \mathrm{~B}$ and C). Further trace element analyses of the hundreds of dikes might allow for further division on geochemical plots, but this was outside the scope of this study. Volcanic rocks from the region were also only sparsely analyzed for trace elements, so only a tentative mafic/felsic split was observed. Mafic dikes from the southern part of the map area have high Sr/Y ratios (fig. 15), which is common in the Western Alaska Range (Todd, 2019, personal commun.). A few textural and compositional differences in the dikes are shown in figure 16A. The dikes are spatially distributed widely across the map area, and dikes form swarms in the northern part of the field area (hatched pattern on map; fig. 16B), as well as the southwestern corner (figs. 16C and D). The timing of felsic folded dikes in the sedimentary rocks is complex because many dikes cross-cut the sedimentary layers and some (outside the map area and seen from a helicopter) follow weaknesses such as fold hinges, suggesting a population of Cretaceous felsic dikes concurrent with folding in the Kahiltna assemblage. Unfortunately, since many dikes do not have age constraints, they cannot aid in unraveling the structural story for the region; providing complexity rather than clarity.

\section{Eocene to Oligocene Volcanic Rocks}

Volcanic rocks cover a significant portion of the Lime Hills C-1 Quadrangle. Caldera centers are delineated by caldera-margin normal faults separating caldera-fill tuffs from older rocks on the margins and from thinner outflow tuffs. The calderas are corroborated by lava domes observed in the field, stratigraphic layering of volcanic rocks (fig. 17A), and fractures interpreted in magnetic and resistivity data (Burns and others, 2019). The volcanic rocks and associated dikes have a very broad composition, ranging between typical basalt $\left(-45\right.$ weight percent $\left.\mathrm{SiO}_{2}\right)$ to very siliceous rhyolite (up to -78 weight percent $\mathrm{SiO}_{2}$; fig. 9), with some extremely high-silica compositions ( $-80-90$ weight percent $\mathrm{SiO}_{2}$ explained by secondary silicification). Mafic volcanics make up less than 10 percent of the unit. Textures in volcanic rocks and dikes are varied, and flattened vesicles imply an original flow fabric (fig. 17D) that was measured when found in place. Generally, the volcanic packages were not divisible at this map scale based on limited chemistry. However, volcaniclastic rocks were noted in numerous places and are represented on the map using point symbols ( $\mathrm{P} v \mathrm{vc})$.

We differentiated textural variances within the previously named Tertiary volcanic rocks of Gamble and others (2013) including many volcaniclastic and epiclastic rocks (figs. $17 \mathrm{~B}$ and $\mathrm{C}$ ). Important cross-cutting relationships between the volcanic rocks and the Eocene Merrill Pass plutonic rocks were also observed and noted (fig. 14B) and helped differentiate the Eocene pluton from the older Paleocene Styx River pluton. 


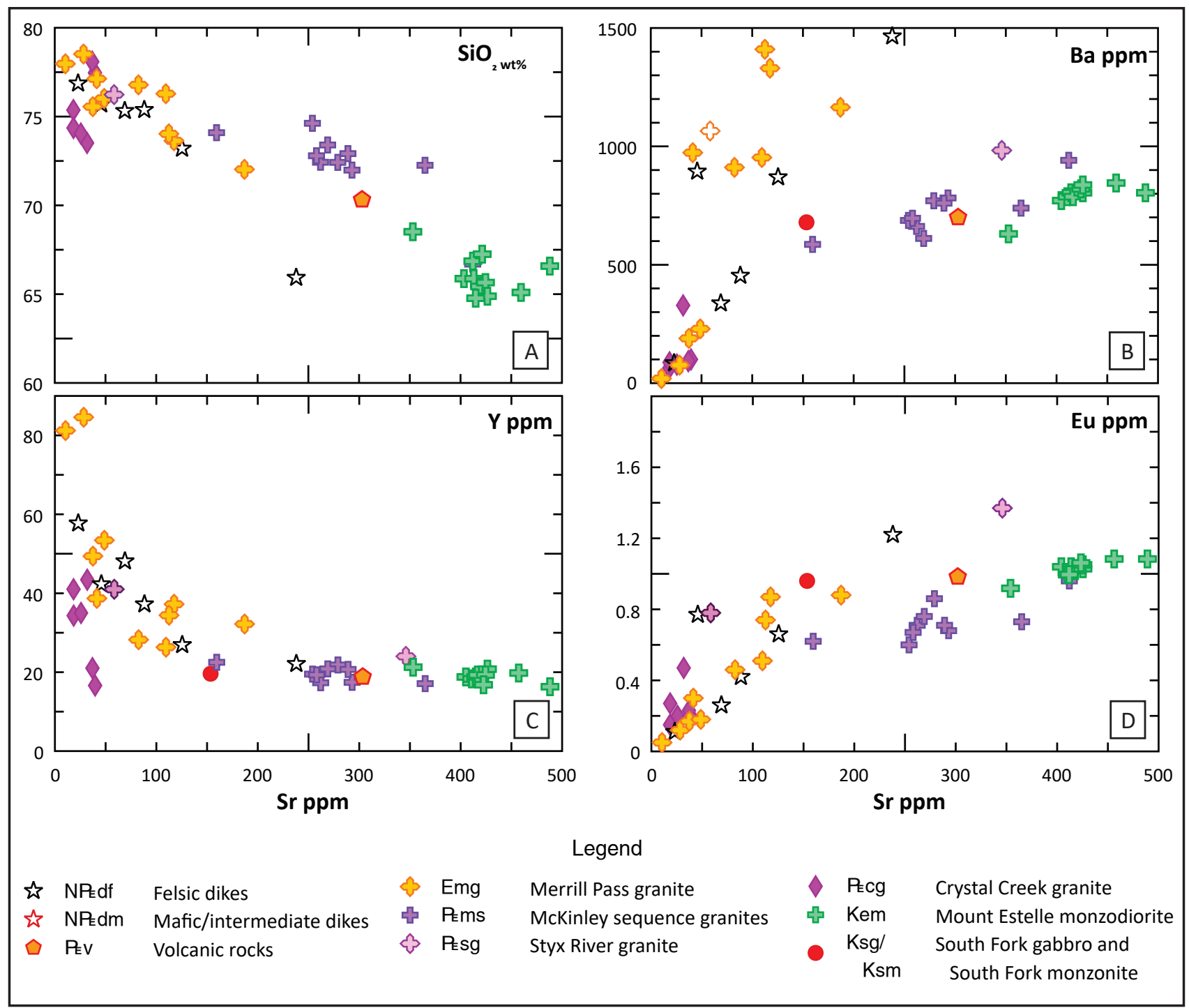

Figure 15. Trace and major element groups and variations for felsic units. Selected major and trace elements are plotted versus Sr concentration to illustrate geochemical differences between felsic plutonic rocks.

\section{ECONOMIC GEOLOGY}

The immediate area surrounding the Styx River map hosts significant mineral resources including porphyry copper \pm molybdenum \pm gold (Whistler, Island Mountain), reduced intrusion-related gold (Estelle property, Terra), and polymetallic veins (Estelle). Mineralization in and around the Mount Estelle pluton led to significant mineral exploration including reduced intrusion-related gold, polymetallic sheeted veins, and molybdenum-bearing quartz veins. The Late Cretaceous and Paleogene plutonic complexes, dike swarms, and volcanic fields are the primary sources or hosts of these mineral occurrences.

\section{EXPLORATION HISTORY}

The Lime Hills C-1 Quadrangle has attracted significant exploration interest. Nearly half of the area has been covered by mining claims at some point during past decade, but to date there has been no recorded lode or placer production.

USGS geologists investigated the Jimmy Lake prospect during reconnaissance geologic fieldwork in 1969 (Reed and Elliot, 1970). Early exploration 

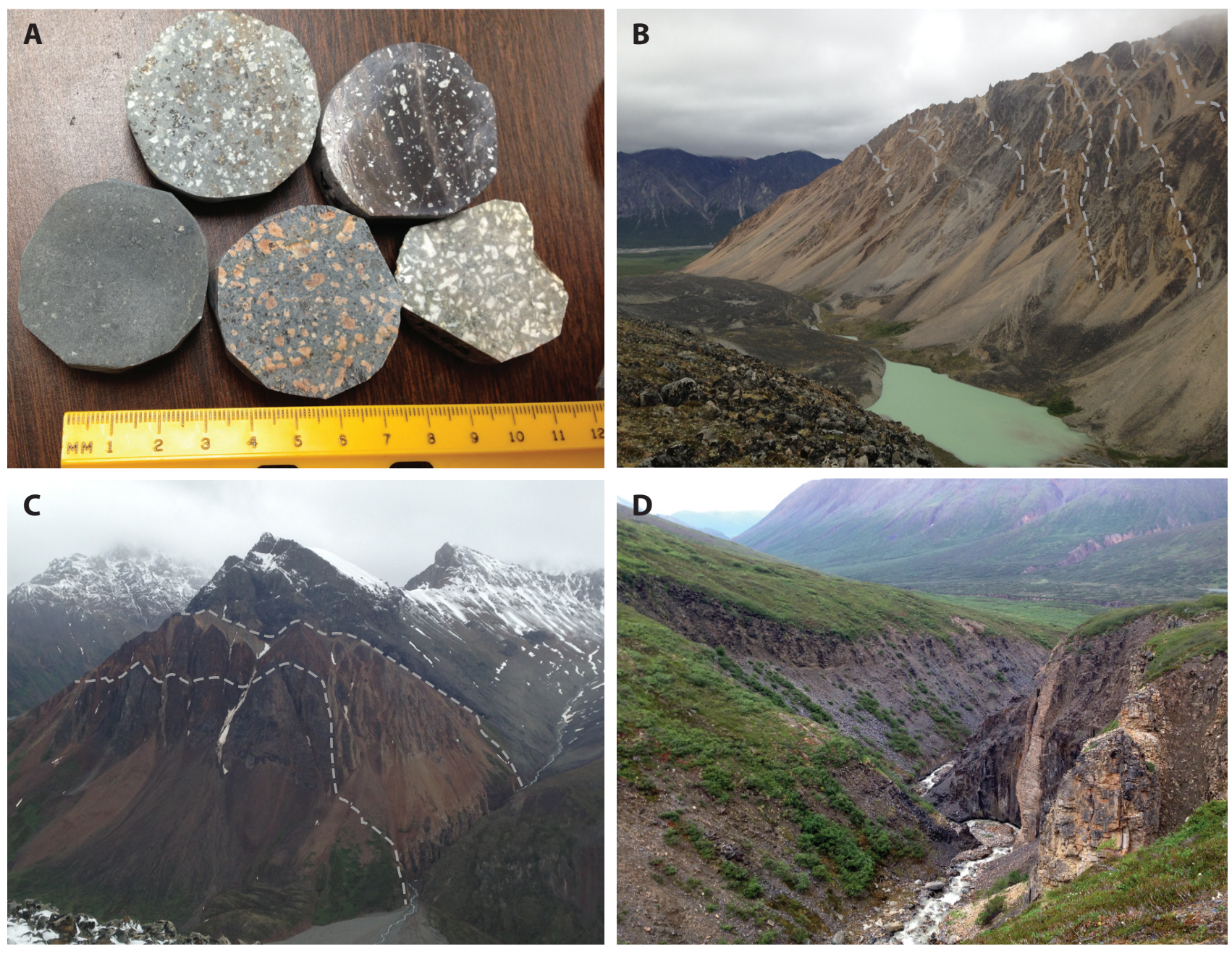

Figure 16. A. Dike and volcanic rock textural variations in hand sample (Sicard and others, 2014a, 2014b). B. A dike swarm in the northeast corner of the map area. Steeply dipping, northwest-striking, mostly felsic dikes intrude into the Estelle pluton above a small glacial lake. The dike swarm also continues to the location of this photo (Station 13DR030), and east across the Styx River (visible in the left of the image), intruding the Kahiltna assemblage by Jimmy Lake, likely offset by large valley faults. This mostly felsic dike swarm is also present in a region in the southwest part of the map. C. View looking south at a dike swarm cutting across the field of view from left to right, where the separate dikes become more visible on the steep slope to the right. D. In the valley just north of photo $\mathrm{C}$ the dikes cut across hornfelsed shales and sandstones of the Kahiltna assemblage. Felsic tan dikes about 2 meters wide are seen in the approximately 10-meter-tall vertical walls.

in the northern part of the map area was conducted by the St. Eugene Mining Company, which staked claims in the Jimmy Lake area in 1970. Bundtzen and others (1982) refer to a mineralized drill intercept at the Jimmy Lake prospect.

Initial exploration on the Copper Joe prospect (at that time known as the Gamo claims) was completed by Amax Exploration Inc. (AMAX) in 1979 and 1980. This included geological mapping, rock and soil geochemical sampling, ground magnetics, and gamma spectrometer surveys. AMAX drilled three diamond drill holes totaling 1,500 feet $(457 \mathrm{~m})$ in the quartz-sericite-pyrite alteration zone at Hades Gulch (fig. 18), encountering weak molybdenum, copper, zinc, lead, and silver mineralization associated with quartz-pyrite veining (Mike Roberts, Kiska Metals Corp., unpub. data, 2014). Kennecott Exploration re-staked the property in 2006 during regional exploration and conducted geological mapping, rock- and stream-geochemical sampling, and ground magnetic surveying. Kiska Metals Corporation began work on the property in 

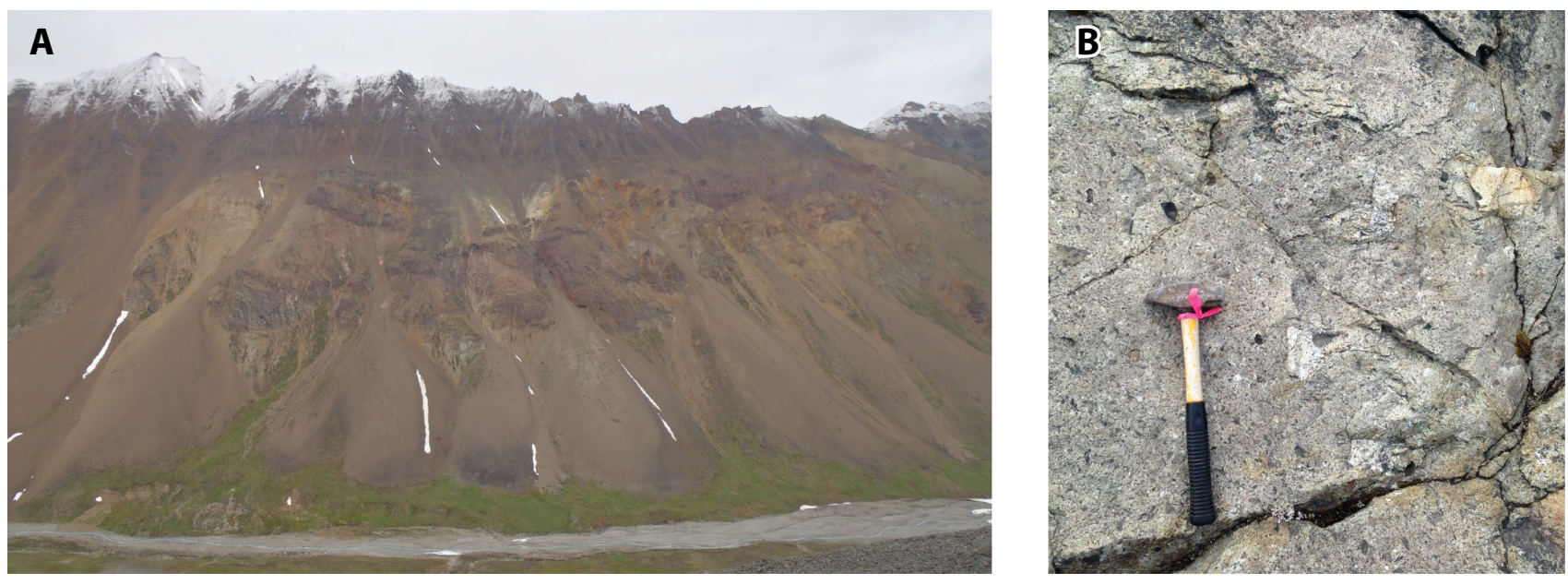
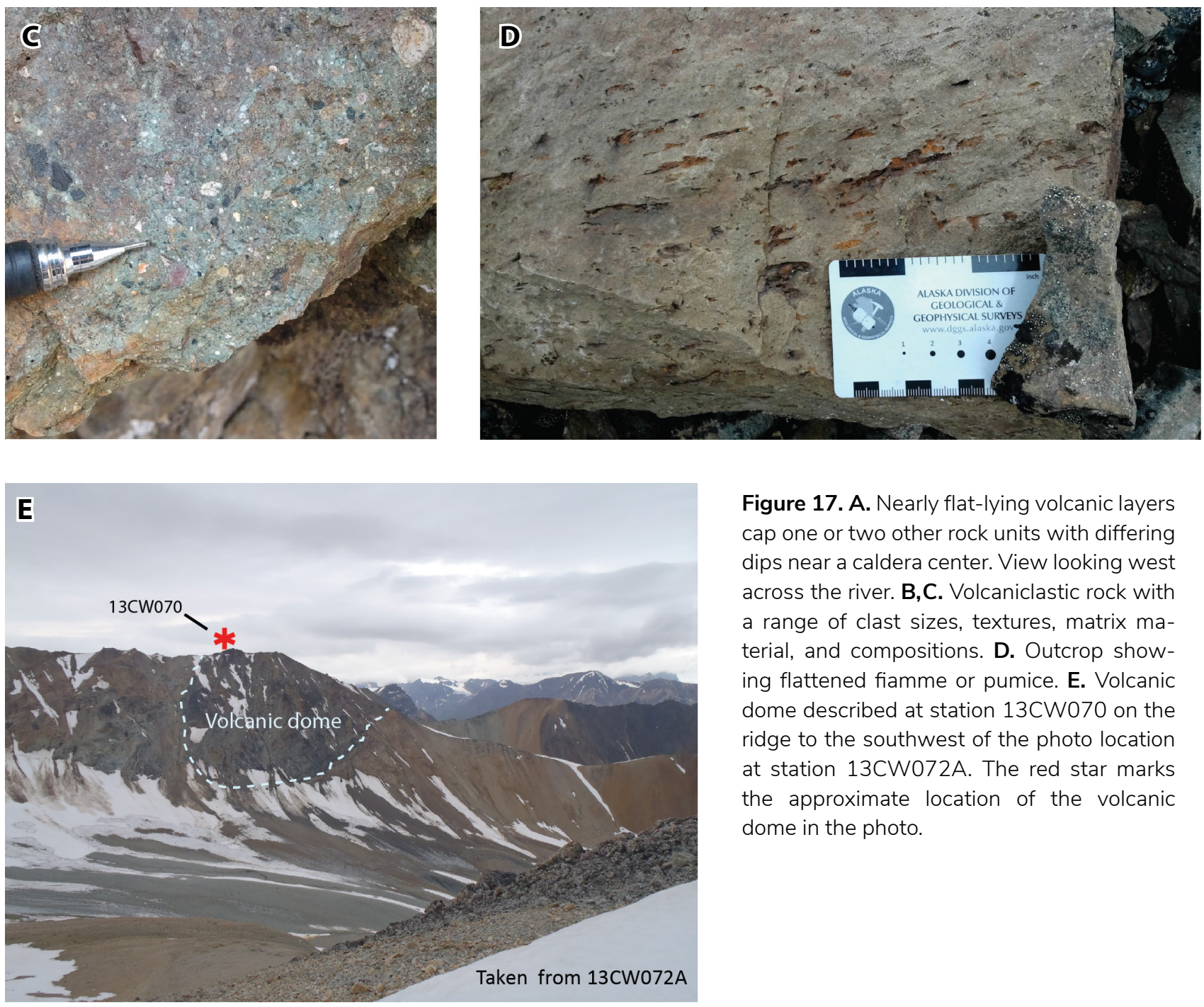

Figure 17. A. Nearly flat-lying volcanic layers cap one or two other rock units with differing dips near a caldera center. View looking west across the river. B,C. Volcaniclastic rock with a range of clast sizes, textures, matrix material, and compositions. D. Outcrop showing flattened fiamme or pumice. E. Volcanic dome described at station 13CW070 on the ridge to the southwest of the photo location at station 13CW072A. The red star marks the approximate location of the volcanic dome in the photo. 
2010 and completed an induced-polarization (IP) geophysical survey (Roberts, unpub. data, 2014). Two holes totaling 2,903 feet $(885 \mathrm{~m})$ drilled under an agreement with First Quantum Minerals Ltd. intercepted hydrothermal and rock-flour breccia, alteration, and trace chalcopyrite (Roberts, unpub. data, 2014).

\section{Types of Mineralization}

Mineralization in the Lime Hills C-1 Quadrangle is dominated by: 1) $\mathrm{Au}-\mathrm{Cu}$ mineralization associated with the margins of the latest Cretaceous Mount Estelle monzogranite (unit Kem); 2) widely scattered Ag-bearing polymetallic occurrences associated with dikes, veins, and faults of a range of ages, and; 3) the large, Miocene-age Copper Joe porphyry copper prospect with quartz-sericitepyrite and locally potassic alteration.

Trace-element analyses of visibly mineralized rocks were used by DGGS geologists to identify alteration and to evaluate the area's mineral resource potential (Sicard and others, 2014a). With the exception of the $\mathrm{Au}-\mathrm{Cu}$ mineralization, there is a positive correlation between $\mathrm{Cu}, \mathrm{Ag}, \mathrm{Sn}, \mathrm{Bi}$, and In (Indium), among other metals. Mo is independent of $\mathrm{Cu}$ mineralization and is instead positively related to $\mathrm{Bi}$ and Te. Figure 19 illustrates some of the geochemical patterns found in the study area.

\section{Polymetallic Mineralization}

Ag-rich polymetallic mineralization occurs throughout the study area, including previously documented occurrences (for example, Jimmy Lake and other 'Unnamed' prospects; Hudson and Millholland, 2002) and additional occurrences documented during the course of this study (mapsheet 1; app. A). Many of these mineral occurrences are localized in or near northwesterly trending map-scale faults or northwesterly trending dikes, and two of the most prominently mineralized areas, Jimmy Lake and the 'Styx River' unnamed occurrences, fall along the same northwesterly trend.

Polymetallic mineralization is characterized by scattered quartz-sulfide veinlets, stockworks,

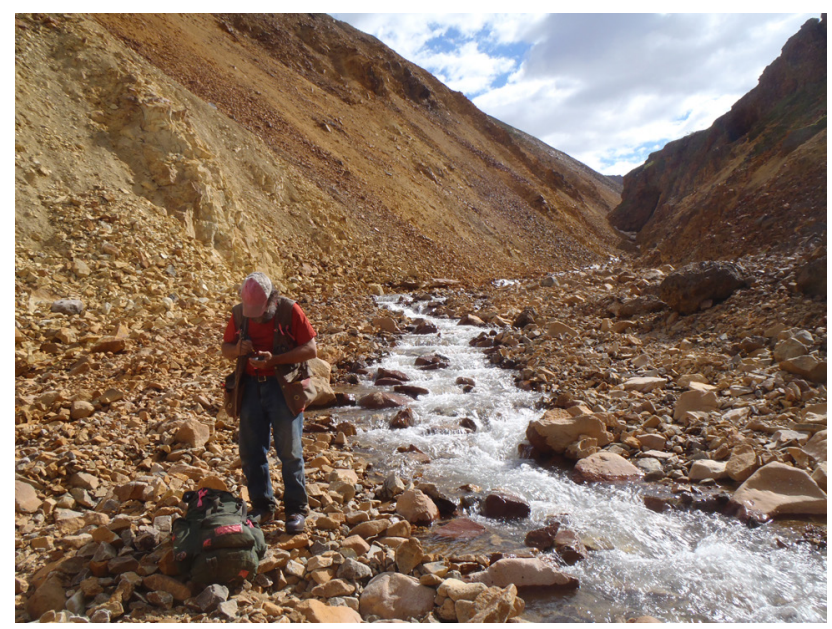

Figure 18. Hades Gulch within the Copper Joe area near station 13RN204A (Ar 2 on map). View is to the south. Red ferricrete terraces are high on the canyon walls.

fault-filling veins, and disseminated sulfides associated with altered dikes. Field-identified sulfide minerals include pyrite, pyrrhotite, chalcopyrite, galena, and arsenopyrite; fluorite and tourmaline are also present.

Sericite from a sericite-altered, northwest-trending, $\mathrm{Cu}-\mathrm{Ag}$ (As-In-Sn-Bi)-mineralized dike yielded an ${ }^{40} \mathrm{Ar} /{ }^{39} \mathrm{Ar}$ age of $63.9 \pm 0.5 \mathrm{Ma}$ (Benowitz and others, 2014). Coeval(?) polymetallic mineralization carrying $\mathrm{Cu}-\mathrm{Ag} \pm \mathrm{Au}$ (Se-In$\mathrm{Sn}-\mathrm{As}-\mathrm{Bi}-\mathrm{Te}$ ) occurs at the margin of the South Fork pluton and yielded a magmatic hornblende ${ }^{40} \mathrm{Ar} /{ }^{39} \mathrm{Ar}$ age of $63.8 \pm 0.4 \mathrm{Ma}$ (table 2 ; Benowitz and others, 2014).

Other anomalous $\mathrm{Ag}-\mathrm{Cu}$ (Bi-Sn-Te-In) rocks occur in or are spatially associated with mostly northwest-striking faults and dikes that crosscut the Paleogene volcanic unit (PEv) and the Eocene Merrill Pass pluton (Emg). Additionally, some of the mineralization at the Copper Joe prospect carries a similar polymetallic geochemical signature; sericite from one $\mathrm{Cu}-\mathrm{Ag}-\mathrm{Te}-\mathrm{In}$ mineralized sample yielded an ${ }^{40} \mathrm{Ar} /{ }^{39} \mathrm{Ar}$ age of $10.7 \pm 0.1$ $\mathrm{Ma}$ (table 2; Benowitz and others, 2014).

\section{Au-Cu Mineralization}

$\mathrm{Au}-\mathrm{Cu}$ mineralization occurs at the margin of the Mount Estelle pluton (unit Kem) and approx- 


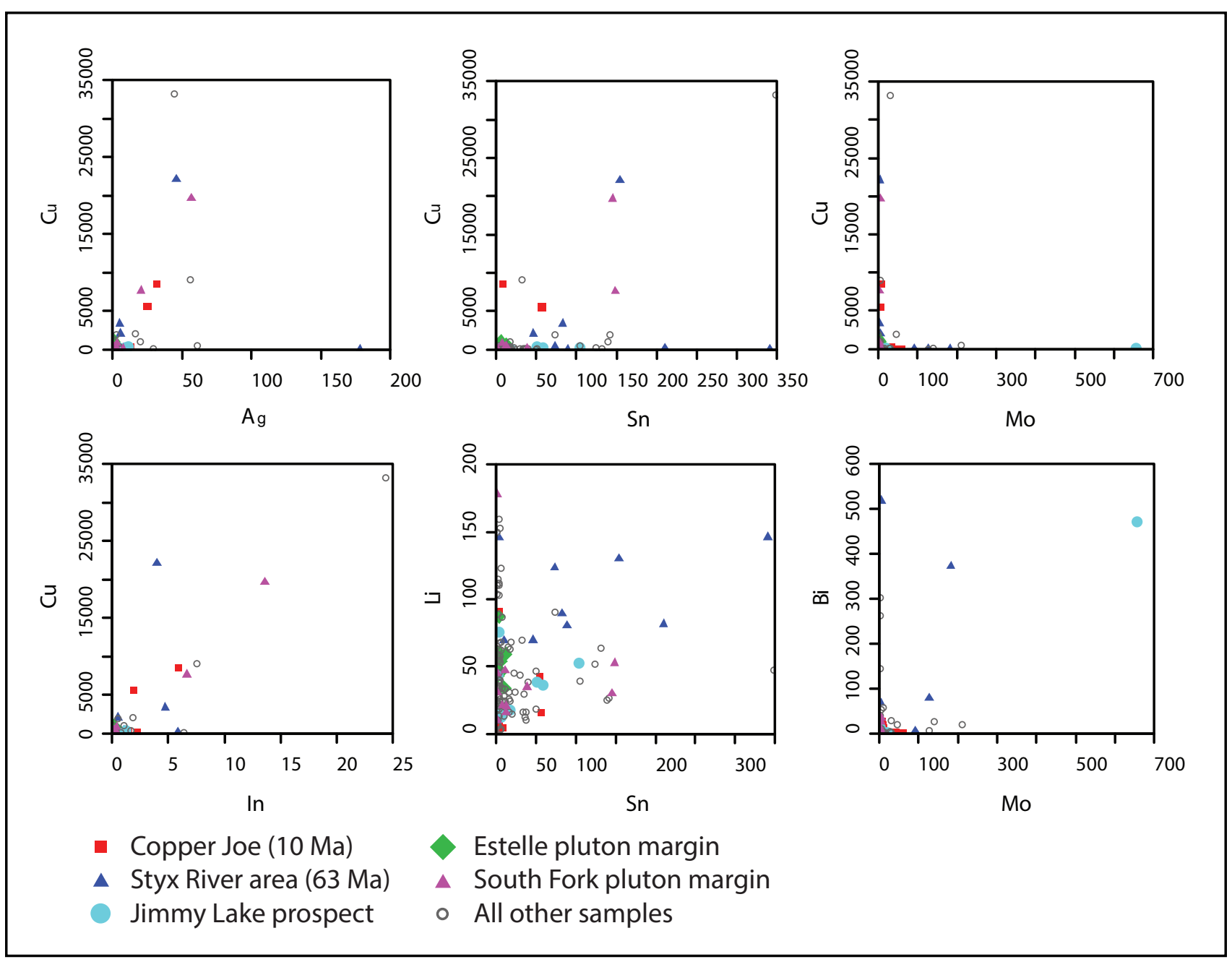

Figure 19. Bivariate trace element plots showing rock geochemical data from this project (Sicard and others, $2014 \mathrm{~b}$ ).

imately $500 \mathrm{~m}$ into the adjacent gossanous hornfels (unit Kkw) in the northeastern Lime Hills C-1 Quadrangle (Near stations 13LF096A-13LF100B, see sample descriptions). Mineralization consists of low-sulfide quartz-carbonate-chlorite veinlets in granitic rock and up to 5 percent disseminated pyrite-pyrrhotite-chalcopyrite sulfide in hornfels. $\mathrm{Ag}, \mathrm{Bi}, \mathrm{Te}$, and $\mathrm{As}$ are not anomalous. Dikes cutting the sedimentary rocks near the Estelle Shoeshine prospect are cut by vein sets, and appear more randomly oriented (Graham and others, 2013; Cody Pink, unpub. data, 2011).

Mineralization is thought to be related to pluton emplacement. The minimum age for the Mount Estelle monzogranite is established by a crosscutting dike about $3 \mathrm{~km}$ to the southeast of the aforementioned mineralization, which has a hydrothermal sericite ${ }^{40} \mathrm{Ar} /{ }^{39} \mathrm{Ar}$ age of $63.9 \pm 0.4 \mathrm{Ma}$ (table 2: Ar 3; Benowitz and others, 2014). The broader Estelle composite pluton has yielded U-Pb zircon ages ranging from 70.1 to $66.7 \mathrm{Ma}, 15$ to $35 \mathrm{~km}$ north of this occurrence (Taylor and others, 2014).

\section{Copper Joe}

The Copper Joe prospect consists of Miocene porphyry copper-style alteration, veining, and hydrothermal breccias with a footprint greater than $10 \mathrm{~km}^{2}$ in the upper Styx River drainage. The prospect is hosted by plutonic country rock assigned to the Merrill Pass unit and centered on a series of felsic porphyry dikes and a large zone of pervasive sericitic alteration. 
An incised stream cut at Hades Gulch exposes pre- and post-alteration biotite porphyry dikes and stocks several meters to tens of meters wide, as well as a zone of partial to pervasive and texturally destructive quartz-sericite-pyrite alteration. This alteration covers an area of approximately 2.5 by $4.5 \mathrm{~km}$, including the Frost Creek area, and is accompanied by quartz veining and stockwork with local chalcopyrite, molybdenite, and other base metal sulfides. Oxidation of the pyritic alteration has produced an up to 8-m-thick blanket of Quaternary ferricrete in Hades Gulch (fig. 18). A sample of stockwork quartz-pyrite-molybdenite veining cutting pervasive sericitic alteration from this area contains 57.8 parts per million (ppm) Mo (Sicard and others, 2014b). AMAX intersected nine, 10-foot $(3.05 \mathrm{~m})$ intervals of greater than 100 ppm Mo with associated anomalous $\mathrm{Cu}$ values, $\mathrm{Ag}$ up to $46 \mathrm{ppm}$, and elevated $\mathrm{Pb}$ and $\mathrm{Zn}$ (Roberts, unpub. data, 2014).

A 1,400-m length of discontinuous creek exposure in Frost Creek in the north-center of the prospect exposes a variety of locally developed quartz veinlets, breccias, K-feldspar-biotite-magnetite alteration, and banded quartz-magnetite veins. Monolithic hydrothermal-type breccias cut altered rocks and include magnetite and biotite cement. Sericite-pyrite- and sericite-hematite-altered rock-flour breccias also occur in the Frost Creek area (Roberts, unpub. data, 2014). A sample of quartz-sulfide veinlets and sericitized wall rock in the Frost Creek area contains 0.85 percent $\mathrm{Cu}$, $31.9 \mathrm{ppm} \mathrm{Ag}, 0.125 \mathrm{ppm} \mathrm{Au}$, and $11.1 \mathrm{ppm} \mathrm{Te}$ (Sicard and others, 2014b).

The age of the Copper Joe hydrothermal system is constrained by $\mathrm{K}$-Ar dating of a non-mineralized, presumably early post-alteration, porphyry dike at $9.9 \pm 0.4 \mathrm{Ma}$ (table 2 ; Roberts, unpub. data, 2014). Hydrothermal sericite yielded ${ }^{40} \mathrm{Ar} /{ }^{39} \mathrm{Ar}$ ages of $10.7 \pm 0.1$ and $11.5 \pm 0.1 \mathrm{Ma}$ (table 2; Benowitz and others, 2014).

\section{DISCUSSION}

\section{Structural and Magmatic History}

A preliminary structural sequence in the Lime Hills C-1 Quadrangle based on field observations supports a qualitative connection between episodes of magmatism and certain dike populations, mineralization events, and fault populations. These interpretations are tentative, and more age control is required to test this sequence of events.

\section{Major Events}

1. Deformation of the Kahiltna assemblage from northwest-southeast-directed compression. Includes faulting and folding from compression and from early Denali Fault movement.

a. Folding of Kahiltna basin sediments created steeply dipping bedding and meso-scale folds (figs. 3, 5, and 6A) constrained by undeformed cross-cutting plutons dated at 80-76 Ma in the Kahiltna sedimentary rocks outside the map area (Todd and Jones, 2017).

Folded and/or faulted felsic dikes within the Kahiltna assemblage (outside the map area) imply some dike emplacement before and during the late Cretaceous. Since radiometric age control is limited, dikes in the map area that post-date folding are labeled Neogene to Paleogene.

2. Late Cretaceous to Paleocene pluton and dike intrusions and associated mineralization..

a. Intrusion of the Mount Estelle and South Fork plutons occurred in the Late Cretaceous between 67-71 Ma. Sulfide and gold mineralization within these units are also hosted in some of the area's equigranular, porphyritic, and aplitic dikes. One mineralized dike within the Mount Estelle pluton has a sericite ${ }^{40} \mathrm{Ar} /{ }^{39} \mathrm{Ar}$ isochron age of $63.9 \pm 0.4$ Ma (Benowitz and others, 2014), suggesting an episode of mineralization in the Late 
Cretaceous or early Paleocene. Dikes cutting the sedimentary rocks are also cut by vein sets (Graham and others, 2013; Cody Pink, unpub. data, 2011). Intrusion of the Crystal Creek Granite, McKinley Sequence Granite, and Styx River Granite.

b. North-to northwest-striking, 60- to 70-degree-dipping, mineralized veins and porphyry dikes cut the intrusive bodies and the aplite dikes (figs. 8C and D). Kinematics on shear zone-hosted veins suggests dip-slip normal movement during mineralization (Cody Pink, 2011, unpub. data). These types of faults and dikes likely resulted from dominantly east-west extension and might be related to a graben forming event.

3. Uplift and erosion of the Late Cretaceous to Paleocene plutons occurred prior to the late Eocene eruption of volcanic rocks in this part of the western Alaska Range,

a. Volcanics were largely rhyolite tuffs with minor basaltic tuffs or flows. The volcanic units include evidence of relict caldera complexes, rhyolite domes, and volcaniclastic deposits.

b. The late Eocene Merrill Pass pluton was intruded beneath broadly contemporaneous volcanic rocks and into the surrounding Styx River Granite.

4. The fault bounded north-south oriented Styx River valley and the South Fork of the Kuskokwim valley could be west side down grabens to the west of both the Mount Estelle and the South Fork plutons:

a. Grabens are inferred from deep-sediment fill interpreted using airborne resistivity data (Burns and others, 2019) and north-south fault patterns in stereonet (fig. 7A). Although the linear valleys could be the result of erosional preference along pluton margins, the presence of fault-bound grabens is supported by the strong north-south map patterns combined with observed normal faults parallel to these valleys and the deep fill implied from the resistivity survey. This faulting could be concurrent with strike-slip faulting.

5. West-northwest-trending high-angle brittle leftlateral strike-slip faulting related to Cenozoic movement on the Castle Mountain and Denali Fault strike-slip faults:

a. The last phase of faulting recorded in plutons was likely high-angle brittle strike-slip faulting that cuts most of the rocks in the area. Some of these faults record subhorizontal slickenlines and left-lateral offsets of dikes. Some of these left-lateral strike-slip faults may have served as conduits for the young Copper Joe hydrothermal porphyry system as it intersected graben valleys, but some likely post-date mineralization.

b. The west-northwest trending strike-slip faults (fig. 7A) are likely left-lateral due to being conjugate faults developed from local E-W compression within the broader DenaliCastle Mountain strike-slip fault system.

c. West-northwest faults cut $-56 \mathrm{Ma}$ dikes, therefore putting a maximum age on the faulting (Haeussler and others, 2013).

6. Mineralized porphyritic dikes with sericite or biotite ${ }^{40} \mathrm{Ar} /{ }^{39} \mathrm{Ar}$ ages between 10 and $12 \mathrm{Ma}$, notably around the Copper Joe prospect (Benowitz and others, 2014; Roberts, 2014), suggest a period of Miocene porphyry mineralization in the southern part of the map area. 


\section{DESCRIPTION OF SURFICIAL-GEOLOGIC MAP UNITS}

Map units and locations of surficial contacts were originally published in Gamble and others (2013) and have only been modified slightly for this publication. Field time was focused only on bedrock mapping with no dedicated surficial geologist to conduct the mapping. Glacial limits and glacial deposits have changed drastically since the Gamble and others (2013) map was published, but due to time constraints, minor adjustments to ice limits and Quaternary units of Gamble and others (2013) were only made where in conflict with bedrock stations taken by DGGS geologists in 2013.

\section{UNCONSOLIDATED DEPOSITS}

\section{(Gamble and others, 2013)}

Ice Glaciers (Holocene) - Glaciers of varying thickness, covered by unconsolidated debris.

Qs Surficial deposits, undivided (Holocene to Pleistocene)-Unconsolidated silt, sand, and rocks, including colluvial deposits, solifluction deposits, talus, and undifferentiated alluvial and glacial deposits.

Qa Alluvial deposits (Holocene) - Silt- to boulder-size material in active stream courses. Typically, coarser and more poorly sorted at highest elevations and finer and better sorted at lowest elevations.

Qaf Alluvial fan deposits (Holocene) - Typically poorly sorted, silt- to boulder-size material in alluvial fans and cones.

Qr Rock glaciers (Holocene to Pleistocene)—Poorly sorted, angular, fine- to boulder-size, ice-cemented rock debris.

Qg Glacial deposits, undivided (Holocene to late Pleistocene?) — Sand- to boulder-size material of diverse composition; chiefly till and glacial outwash. Only more prominent lateral and terminal moraines are depicted on the map.

\section{DESCRIPTION OF BEDROCK-GEOLOGIC MAP UNITS}

\section{Sedimentary rocks}

\section{Kahiltna Assemblage}

Through new detailed sandstone petrographic work and detrital zircon populations, the USGS has defined and detailed six petrofacies of the Upper Jurassic to Cretaceous Kahiltna Assemblage in the western Alaska Range. Three are part of the Kuskokwim Group, and three are part of the Koksetna-Clearwater belt (Box and others, 2019). Rocks in the Lime Hills C-1 Quadrangle fall into the Whistler petrofacies of the Kuskokwim Group, and one undivided petrofacies of the Koksetna-Clearwater belt.

Kkw Kuskokwim group, Whistler petrofacies (Upper Cretaceous) —Interbedded mudstone and siltstone, with turbidite sequences grading into well-indurated quartzose sandstone. Dark gray to brown. Well-consolidated, subangular to rounded, coarse- to fine-grained sand. Few granuleto pebble-sized lithic clasts up to $2 \mathrm{~cm}$ in diameter consisting of abundant chert, quartz, and detrital white mica. Thickness of individual beds ranges from a few millimeters to $15 \mathrm{~cm}$. Largescale folding and faulting of bedding is visible on cliff walls, with layer-parallel slip recorded at outcrop scale (Box and others, 2019). Hornfelsed adjacent to dikes and plutons. Replacement of original grains, moderate recrystallization, and development of slaty cleavage are present in 
thin section and are generally axial planar to stratal folds. Upper Cretaceous age is based on detrital zircon uranium-lead (U-Pb) dating (Jones and others, 2014; Karl and others, 2013; Box and others, 2019). Correlates with the upper Kuskokwim Group, Whistler petrofacies of Karl and others (2016). Magnetic susceptibility is relatively low averaging 0.71 x $10^{-3}$ Système International (SI).

KJk Koksetna-Clearwater Belt, Undivided (Upper Cretaceous to Upper Jurassic)_Interbedded mudstone-graywacke turbidite sequence and minor volcanic flows. Lithic grains consist of argillite, chert, and volcanic rocks; sedimentary and volcanic lithic grains are present in approximately equal amounts. Strongly hornfelsed locally. Tentatively correlated with the Koksetna-Clearwater belt of Box and others (2019) based on geographic location. Box and others (2019) report Koksetna-Clearwater belt samples within $25 \mathrm{~km}$ to the north, east, and south that must be Upper Cretaceous in age because they contain Upper Cretaceous detrital zircon age population peaks as young as 89 Ma. Previously correlated to the Koksetna River sequence of Wallace and others (1989) based on overall lithologic composition (Gamble and others, 2013). Around 40 $\mathrm{km}$ south of the map area, megafossils within this unit yielded Kimmeridgian (Upper Jurassic) and Valanginian (Lower Cretaceous) ages (Eakins and others, 1978). However, the location of these sedimentary rocks on top of the likely younger Paleocene Crystal Creek granite ( $\mathrm{F} c \mathrm{cg})$ warrants further study. Magnetic susceptibility is relatively low, averaging $1.59 \times 10^{-3} \mathrm{SI}$.

\section{Volcanic Rocks}

Volcanic rocks and dikes were differentiated and named based on their published broad lens X-Ray Fluorescence (XRF) data and major oxide geochemical data (Sicard and others, 2013, 2014b, 2014c) and plotted on total alkali-silica (TAS) diagram (fig. 9A) and trace-element plots (fig. 9B-G). Unit calls for these rocks are released with this report in the map database. Two main groups of volcanic and volcaniclastic rocks were distinguished from field descriptions and geochemical data; a crystal lithic felsic tuff, usually of rhyolitic composition, and a lithic crystal tuff and volcaniclastic to epiclastic conglomerate or breccia, primarily based on textural descriptions. The volcaniclastic rocks ( $\mathrm{P} v \mathrm{vc}$ ) were discontinuous and are displayed as point observations on the map. A third group was not able to be divided into its own unit; mafic volcanic rocks (primarily based on silica composition) comprise less than 10 percent of all the volcanic rocks and are described below, within unit Pev for completeness.

Pav Volcanic Rocks, Felsic to Mafic (Paleogene)_-Two main compositional groups of volcanic and volcaniclastic rocks were noted from field descriptions and geochemical data; a felsic group and a mafic to intermediate group primarily based on composition, namely silica content (fig. 9). Compositional layering is heterogeneous, complex, and while visible in the field, remains indivisible at map scale. About 90 percent of the volcanic rocks are identified as felsic based on field descriptions or geochemistry and the remaining 10 percent are mafic to intermediate rocks (see map database; Sicard and others, 2013, 2014b, 2014c).

The felsic group is composed of crystal-rich tuff, lithic-rich tuff, breccia, and conglomerate, with multiple graded, epiclastic deposits alternating with ash-flow tuff (fig. 17). True thickness is unknown, but likely varies widely with proximity to the inferred caldera in the centralwestern map area. In its thickest exposed section, this layered volcanic unit spans approximately 2,800 feet of elevation and layering is near horizontal to gently dipping. Ring fractures, steep to vertical flow banding, arcuate steep contacts in map pattern, geophysical lineaments, and 
intrusive relationships suggest at least one caldera in the central-western part of the map area (delineated by arcuate normal faults) with a lava dome noted on the map as well. The volcanic rocks unconformably and topographically overlie the Paleocene Styx River granite (PEsg) and generally overlie the Eocene Merrill Pass granite (Emg) but are also intruded from beneath by felsic dikes appearing to be Emg, suggesting a coeval relationship (fig. 14A). This makes sense since their ages overlap within error. Volcanic rocks range from 33.6 $\pm 3.4 \mathrm{Ma}$ to $41 \pm 1.6$ Ma from ${ }^{40} \mathrm{Ar} /{ }^{39} \mathrm{Ar}$ dating (Gamble and others, 2013). Volcanic rocks are also cut by coeval and younger felsic dikes. Magnetic susceptibility varies greatly, and there is remnant magnetism showing reverse magnetic anomalies. An average of all volcanic rocks in the map area yields a magnetic susceptibility of $1.71 \times 10^{-3}$ SI.

Coherent felsic rocks are aphanitic to medium-grained dacites and rhyolites, with potassium feldspar, hornblende, and biotite phenocrysts. Groundmass is locally flow-banded. Chiefly crystal-rich and crystal-lithic-rich biotite-hornblende rhyolite tuffs with ash-fall, ash-flow, and brecciated tuff to volcanic conglomerate. Phenocrysts make up 15 percent of the felsic volcanic rocks and exist in a matrix of very fine-grained (mostly less than $0.5 \mathrm{~mm}$ ) subhedral plagioclase, weathered biotite, glass, and very weathered hornblende. Plagioclase and biotite crystals in the matrix typically appear aligned, signifying original flow direction. The phenocrysts are composed of fragmented subhedral biotite (averaging $5 \mathrm{~mm}$ ) and potassium feldspar (averaging $7 \mathrm{~mm}$ ) in roughly equal proportions, and slightly less hornblende (averaging $5 \mathrm{~mm}$ ). Abundant iron-oxide inclusions are present and phenocrysts are significantly overprinted by sericite and clay alteration.

Mafic to intermediate volcanic rocks are primarily fine-grained basaltic-andesite to andesite, which are porphyritic, vesicular/amygdaloidal, and often characterized by a dark gray to green matrix with minor phenocrysts. Rare, 1-mm-long euhedral plagioclase, hornblende, and biotite phenocrysts comprise up to 2 percent of the rock. Amygdules of calcite and chalcedony are present in vesicular samples. Magnetic susceptibility is slightly higher than felsic and epiclastic parts of the unit, but still relatively low, averaging $1.73 \times 10^{-3} \mathrm{SI}$.

Pavc Volcaniclastic Rocks (Paleogene)_Volcaniclastic rocks are predominantly angular to subangular, matrix to clast-supported breccia with a generally aphanitic matrix (fig. 17B and C). Volcanic clasts are composed of predominantly felsic volcanic fragments, with pumice and fiamme. Minor epiclastic conglomerate is present. The matrix and rock are very hard and indurated; often slightly welded or hornfelsed, usually white, but also gray to light purple, or green, and composed of very-fine-grained to granule-size felsic volcanic clasts. The presence of welded tuff is indicated by the strong induration and the presence of rare fiamme. Graded bedding is locally present, as is significant rounding of the clasts indicating the presence of lahar and/or alluvial volcaniclastic and epiclastic deposits. Epiclastic components include granite, slate, argillite, and metasandstone. Magnetic susceptibility is relatively low, averaging $1.49 \times 10^{-3} \mathrm{SI}$.

\section{Dikes}

The two divisions of dikes based primarily on silica composition and mineralogy are felsic and mafic. Dikes were divided based on their silica composition or rock descriptions. Most dikes were not geochemically analyzed due to the high number of samples and limited budget. Samples are located at the Alaska Geologic Materials Center.

A few dikes were analyzed with a full major oxide and trace element geochemical suite; these dikes are 
divided into those with a low HREE signature versus those with a high HREE signature. The low HREE dike signature is similar to Late Cretaceous to Paleocene plutons (Ksg, Kem, PEsg, Pecg) whereas the high HREE signature is similar to younger Merrill Pass granite and volcanic rocks (Emg and Pev). However, this division is incompletely based on a few samples, thus is inapplicable to the whole map area. Dikes intruding these younger units are interpreted as Miocene to Eocene in age, and described as a subset of the larger groupings.

NPEdf Felsic Dikes (Neogene to Paleogene)_Fine- to medium-grained, porphyritic dikes of primarily rhyolite composition with phenocrysts of plagioclase, potassium feldspar, quartz, biotite, and rare hornblende. Phenocrysts make up 10-15 percent of dikes, are subhedral, up to 1-cm long, and are mainly albitic plagioclase with polysynthetic twins, complex zoning, resorbed cores, and some rim replacement. About 15 percent of the phenocrysts are subhedral potassium feldspar, up to $1-\mathrm{cm}$ long, with zoning and sericite alteration. The remaining phenocrysts are up to 30 percent, 1- to 5-mm-diameter anhedral quartz, 2-15 percent, 1- to 7-mm-diameter, subhedral biotite, often with pervasive chlorite replacement, and less than 10 percent, fine-grained hornblende, almost completely replaced by chlorite and very fine-grained clay aggregate. Matrix is very fine-grained, recrystallized, and altered. Light greenish tan to dark gray, weathering to a rusty tan to gray. These dikes have trace-element-indicated tectonic signatures of volcanic arc and within-plate settings; within-plate dikes are geochemically similar to Crystal Creek and Merrill Pass granites (Sicard and others, 2013, 2014b, 2014c). Felsic dikes have a similar HREE signature as surrounding felsic plutons and volcanic rocks (Emg, PEsg, PEcg, and PEv), and a contrastingly high HREE signature compared to mafic to intermediate dikes (NPEdm). Their rare earth element geochemistry is very similar to Merrill Pass, Styx River, and Crystal Creek granites, and their geographic association with these plutons suggests similar Paleocene (ca. $60 \mathrm{Ma}$ ) and Eocene (ca. $35 \mathrm{Ma}$ ) ages.

A subset of felsic dikes intruding Eocene-Oligocene volcanic rocks and Merrill Pass granite are likely Miocene to Eocene in age. Mineralized dikes associated with a Miocene sericite alteration zone at the Copper Joe prospect are ca. $10 \mathrm{Ma}$. Felsic dikes are very abundant throughout the map area but are generally less than two meters wide. Magnetic susceptibility in felsic dikes is relatively low, averaging $0.97 \times 10^{-3} \mathrm{SI}$.

NPEdm Mafic to Intermediate Dikes (Neogene to Paleogene)_Porphyritic dacite to basalt dikes. Mafic dikes are gray to black and dark green, and weathering rusty maroon. Phenocrysts are commonly 10-15 percent (but up to 60 percent), 5- to 10 -mm-diameter, subhedral, zoned plagioclase; less than 10 percent, 1 - to 3-mm-diameter, euhedral, biotite; and less than 10 percent, 1 - to 3-mm-diameter, euhedral to subhedral hornblende. Phenocrysts are commonly altered, with sericitized plagioclase, chloritized hornblende, and biotite crystals with opaque inclusions. There are local vesicles, calcite-filled amygdules, and chloritization of the matrix. HREE concentrations are low as in surrounding mafic Late Cretaceous to Paleocene plutons (Ksg, Kem, Pesg, Pecg). Dates of possibly correlative basalt to basaltic andesite mafic dikes clustering around ca. 58 to $51 \mathrm{Ma}$ are found within $10 \mathrm{~km}$ northeast of the map area (Ayuso and others, 2014; Haeussler and others, 2013) with relatively light REE-rich/Chrondrites. A subset of mafic dikes intrudes Oligocene-Eocene volcanic rocks and Merrill Pass granite ( $\mathrm{P} v \mathrm{~V}$ and Emg) and are likely Miocene to Eocene in age but indivisible within this study. Intermediate dikes are light gray to dark green, and weathering rusty red. Phenocrysts are commonly 10-15 percent (but up to 50 percent), 5- 
to 10 -mm-diameter, subhedral, zoned plagioclase; less than 10 percent, 1 - to 3-mm-diameter, euhedral, biotite; less than 10 percent, 5- to 8-mm-long, subhedral, resorbed potassium feldspar; and rare, 1- to 3-mm-diameter, euhedral to subhedral hornblende. Phenocrysts are commonly altered, including sericitized plagioclase, chloritized hornblende, and biotite crystals with opaque inclusions. A subset of intermediate dikes intrudes Oligocene-Eocene volcanic rocks and Merrill Pass granite ( $\mathrm{P} v \mathrm{and} \mathrm{Emg}$ ) and are likely Miocene to Eocene in age but indivisible within this study. Magnetic susceptibility is variable (averaging $3.93 \times 10^{-3} \mathrm{SI}$ ).

\section{Plutonic Rocks}

Plutonic rock names are primarily based on rock chemistry from major oxide chemical analyses plotted on Streckiesen diagrams. Where major oxide data was not available, stained-slab point counts were considered against field rock calls and checked with visual reanalysis of hand samples or thin sections. This map uses previous names from the area, except where major differences were found.

Emg Merrill Pass Granite (Eocene)_Fine- to medium-grained, primarily granite, but ranging to monzonite and granodiorite. Locally porphyritic biotite granite to monzogranite, with local hornblende. Hypidiomorphic-granular crystals consist of about 30-40 percent plagioclase, about 30 percent potassium feldspar, less than 30 percent quartz, up to 20 percent biotite, and up to 10 percent hornblende. White to gray to black, but extensively weathered to gray and brown. Locally exhibits intense chlorite and sericite alteration, with exsolved feldspar (albitemicrocline) and rare myrmekite. Mafic minerals are chloritized and replaced by chlorite and opaque minerals. Mineral compositions, hypabyssal textures, and miarolitic cavities suggest this pluton cooled close to the surface, 4-6 km deep (E. Todd, personal commun., 2014; Lund and others, 1986). Major-oxide and trace element geochemistry from this study characterizes the Merrill Pass pluton as a volcanic arc to within plate granite (fig. 3B; $\mathrm{Y}+\mathrm{Nb}$ ), ferroan, primarily calc-alkalic, and peraluminous (figs. 4A-C).

This unit was mapped based on high magnetic signature in airborne magnetic data (Burns and others, 2019), and refined by textural calls. Magnetic susceptibility of unaltered rocks can be locally high, but was low from measured samples, averaging $1.15 \times 10^{-3}$ SI. Texturally and geochemically, this unit is almost indistinguishable from the older $-60 \mathrm{Ma}$ Styx River granite ( $\mathrm{Essg}$ ), but it is correlated to the large Eocene Merrill Pass pluton $-4 \mathrm{~km}$ to the south of the map area based on a 31.2 Ma K/Ar date from within the Copper Joe area by Kiska Metals Corp. (table 2, sample Ar 6; from Roberts, unpub. data, 2014). This correlation is also supported by unpublished USGS geochemistry and dates (Erin Todd, written commun, 2019) and by biotite $\mathrm{K}-\mathrm{Ar}$ and ${ }^{40} \mathrm{Ar} /{ }^{39} \mathrm{Ar}$ ages ranging from ca. 35.6 to 40.0 Ma (Reed and Lanphere, 1972) and ca. 40.0 Ma to 41.6 Ma (Gamble and others, 2013). An approximately 3-square-kilometer area intruded by granite porphyry dikes and containing intense quartz-sericite-pyrite and magnetite alteration associated with copper-molybdenum mineralization constitutes the Copper Joe prospect, Alaska Resource Data File locality number LH020 (appendix A). This alteration zone with mineralization represents Miocene-age porphyry system in the Alaska Range (Benowitz and others, 2014; Roberts, unpub. data, 2014).

Pesg Styx River Granite (Paleocene)-Fine- to coarse-grained, equigranular to seriate, hypidiomorphic-granular, locally porphyritic biotite granite to monzogranite, with local hornblende. Composition varies widely from quartz syenite to syenogranite to alkali feldspar 
granite, with gradational rather than abrupt compositional changes (Sicard and others, 2014b; 2014c). Light gray to light pink, weathering to rusty tan or black. A representative phase of the pluton contains about 30 percent anhedral, interstitial quartz with many lattice-aligned inclusions, about 40 percent subhedral to anhedral, $10 \mathrm{~mm}$, potassium feldspar, about 20 percent subhedral plagioclase, 10 percent $5 \mathrm{~mm}$ euhedral biotite, and local, less than 5 percent, $5 \mathrm{~mm}$ subhedral hornblende. Feldspars display little to no zonation, but do exhibit albite and carlsbad twinning, perthitic and myrmekitic textures, and are often sericitized. Many inclusions of opaque minerals occur within biotite and plagioclase. The pluton contains numerous mafic xenoliths ranging from millimeters to tens of centimeters in diameter, which lack reaction rims and are found locally near pluton margins. Major-oxide and trace element geochemistry from this study characterizes the Styx River pluton as a volcanic arc to within plate granite (fig. 3B; $\mathrm{Y}+\mathrm{Nb}$ ), ferroan, primarily calc-alkalic, and peraluminous (figs. $4 \mathrm{~A}-\mathrm{C}$ ). Parts of this pluton were previously named Merrill Pass pluton, however, $\mathrm{U}-\mathrm{Pb}$ zircon ages of $60.79 \pm 0.68 \mathrm{Ma}$ and 58.94 $\pm 0.78 \mathrm{Ma}$ using a high-resolution laser ablation split-stream (LASS) (Todd and others, 2017) are significantly different from historic argon ages, which led the authors to distinguish this pluton as a separate Paleocene phase. New unpublished ages for the Merrill Pass pluton to the south of the Lime Hills quadrangle are also much younger (Erin Todd, written commun., 2019). Magnetic susceptibility is generally low (averaging $1.38 \times 10^{-3} \mathrm{SI}$ ).

Pems McKinley Sequence(?) Granite (Paleocene)-Coarse- to very coarse-grained, seriate to porphyritic or equigranular biotite granite. Comprised of about 40-50 percent potassium feldspar, about 30 percent plagioclase, about 25 percent quartz, about 7-20 percent biotite, and rare hornblende. Light gray to greenish gray, weathering to brown. Common sericite alteration of plagioclase, chloritization of biotite, and prehnite overgrowths suggest widespread and postintrusion hydrothermal activity including Jimmy Lake prospect dike system yielding a U-Pb zircon age of $57.4 \pm 1.7$ (table 2, UPb 1; Taylor and others, 2014); ARDF locality number LH012 (app. A). The porphyritic phase contains about 15 percent large, 2- to 15 -cm-diameter, euhedral potassium feldspar phenocrysts. Major-oxide and trace element geochemistry from this study characterizes the McKinley sequence as a volcanic arc granite (fig. 3B; $\mathrm{Y}+\mathrm{Nb}$ ), magnesian, calc-alkalic, and peraluminous (figs. 4A-C). Gamble and others (2013), cited that this phase was dated at $65.0 \pm 0.5 \mathrm{Ma}$, using ${ }^{40} \mathrm{Ar} /{ }^{39} \mathrm{Ar}$ and was tentatively assigned to the McKinley sequence(?) granitic rocks. New geochemistry and $\mathrm{U}-\mathrm{Pb}$ zircon age of $57.4 \pm 1.7 \mathrm{Ma}$ (Taylor and others, 2014), indicates this unit is Paleocene. A geographically northern piece of the pluton trends southsouthwest to the southern part of the quadrangle, but could have been segmented by faulting, pluton emplacement, and caldera formation in the central map area. Magnetic susceptibility is relatively high (averaging $2.21 \times 10^{-3} \mathrm{SI}$ ).

Peg Crystal Creek Granite (Paleocene) —Coarse- to medium-grained, hypidiomorphic granular to equigranular. Primarily quartz syenite to granite, with lesser syenite and alkali feldspar syenite based on geochemistry and feldspar-stained slabs (Sicard and others, 2014b, 2014c). White and orange to light pink and green, weathering to rusty white. Average modal mineralogy is 70-90 percent subhedral potassium feldspar, 15 percent subhedral plagioclase, 10 percent interstitial quartz, and rare mafic minerals. These mafic minerals are very small, often less than $5 \mathrm{~mm}$, anhedral, and composed of mainly iron hydroxides, rare chloritized biotite, and very rare hornblende. Accessory euhedral zircon is present in thin section. Major-oxide and trace element geochemistry from this study characterizes the Crystal Creek pluton as a volcanic arc granite (fig. 3B), ferroan, primarily 
alkali calcic, and peraluminous (figs. 4A-C). Unit yielded concordant biotite and hornblende $\mathrm{K}-\mathrm{Ar}$ ages of 58.5 $\pm 1.7 \mathrm{Ma}$ and $58.4 \pm 2.9 \mathrm{Ma}$, respectively (Reed and Lanphere, 1972). Mineralogy, chemistry, and age data suggest this pluton and the Chilligan porphyry (less than two kilometers south of the map area) might represent a single intrusion (Gamble and others, 2013). Magnetic susceptibility is very low (averaging $0.30 \times 10^{-3} \mathrm{SI}$ ).

Kem Mount Estelle Monzogranite(Late Cretaceous) —Coarse- to medium-grained, hypidiomorphic granular to equigranular to seriate monzodiorite quartz monzodiorite and monzogranite. Light gray to greenish tan, weathering to iron-oxide stained reddish gray. Modal mineralogy averages 50-70 percent subhedral plagioclase, 23 percent subhedral potassium feldspar, 17 percent interstitial quartz, 7 percent subhedral biotite, and 3 percent subhedral to euhedral hornblende. Seriate phase contains polysynthetic-twinned plagioclase averaging $5 \mathrm{~mm}$ in length. Potassium feldspars average $7 \mathrm{~mm}$ in length for microcline and $10 \mathrm{~mm}$ in length for perthitic orthoclase. Hornblende is often twinned, 3 to $5 \mathrm{~mm}$ in length, and replaced by biotite, which is in turn replaced by chlorite. Some biotite crystals range up to $7 \mathrm{~mm}$ in length. Locally, hornblende laths are up to $10 \mathrm{~mm}$ and are broken apart and replaced by micas. Major-oxide and trace element geochemistry from this study characterizes the Mount Estelle pluton as a volcanic arc granite (fig. 3B), magnesian, calc-alkalic, and metaluminous (figs. 4A-C). This pluton was dated within the map area with ${ }^{40} \mathrm{Ar} /{ }^{39} \mathrm{Ar}$ at $62.0 \pm 0.2 \mathrm{Ma}$ (biotite crystallization age) and $61.8 \pm 0.5$ (hornblende crystallization age; Benowitz and others, 2014). However, U-Pb ages likely more accurately reflect the crystallization age of the Mount Estelle pluton and range from ca. 67 to 70 (Taylor and others, 2014). These ages were sampled about 30 kilometers northeast of the map area. This pluton appears reduced, with low magnetic susceptibility (averaging $0.83 \times 10^{-3} \mathrm{SI}$ ).

Ksg South Fork Gabbro (Late Cretaceous) —Coarse- to medium-grained, hypidiomorphic granular to equigranular to seriate. The unit contains a broad range of compositions, originally classified as a hornblende-pyroxene-biotite gabbro, but ranges to granodiorite. A monzogranite phase is interpreted as a younger stock (Ksm) and described below (Gamble and others, 2013). Modal mineralogy averages 10-50 percent subhedral plagioclase, 30 percent clinopyroxene, 30 percent biotite (up to $10 \mathrm{~mm}$ in diameter with inclusions of feldspars and opaque minerals), and 10 percent hornblende; more mafic phases contain about 10 percent olivine, while more felsic phases have less than 5 percent interstitial quartz. Light gray to black in color, weathering to dark gray; locally heavy iron oxide staining. This unit is highly altered, with sericitized plagioclase and pods of fine-grained white mica, biotite, and chlorite replacing hornblende. Major-oxide and trace element geochemistry from this study characterizes all phases of the South Fork pluton as a volcanic arc granite (fig. 3B), magnesian, calc-alkalic to alkali calcic, and metaluminous (figs. $4 \mathrm{~A}-\mathrm{C})$. A previously published age for this gabbroic phase using biotite K-Ar yielded $69.7 \pm 2.0$ $\mathrm{Ma}$ (table 2; KAr 3; Reed and Lanphere, 1972). This is slightly older than the Ksm monzogranite stock $68.0 \pm 1.1 \mathrm{Ma}$ by U-Pb from zircon (table $2: \mathrm{UPb} 4$; Taylor and others, 2014). ${ }^{40} \mathrm{Ar} /{ }^{39} \mathrm{Ar}$ ages: $63.5 \pm 0.4$ (biotite; table 2: Ar 6) and $63.8 \pm 0.4$ (hornblende; table 2; Ar 7) (Benowitz and others, 2014) indicate that there are likely multiple phases of this pluton, slow cooling in a longlived magmatic system, or possibly resetting of the biotite and hornblende through alteration. The magnetic susceptibility is low $\left(0.35 \times 10^{-3} \mathrm{SI}\right)$. 
Ksm South Fork Monzogranite (Late Cretaceous) - Coarse- to medium-grained, hypidiomorphic granular to equigranular to seriate. This felsic phase of the South Fork pluton appears to be a stock, or intrusion of predominantly monzogranite (Gamble and others, 2013), with no more than 5 percent interstitial quartz. Light gray and black, weathering rusty red to light green. Highly altered, with sericitized plagioclase and pods of fine-grained white mica, biotite, and chlorite replacing hornblende. Biotite can be quite large (up to $10 \mathrm{~mm}$ ), with inclusions of feldspars and opaque minerals. The geochemistry was combined for plotting purposes with the Ksg phase since there was limited data. The entire South Fork pluton is classified as a volcanic arc granite (fig. 3B), magnesian, calc-alkalic to alkali calcic, and metaluminous (figs. 4A-C). This monzogranite phase was interpreted as younger than the more mafic gabbroic phase (Ksg) based on cross-cutting relationships and the $68.0 \pm 1.1 \mathrm{Ma} \mathrm{U}-\mathrm{Pb}$ zircon age of this unit determined at an "Unnamed" prospect (ARDF locality number LH019 (app. A) informally named "Orange Ridge" (Taylor and others, 2014). This age is only slightly younger than a previously published $69.7 \pm 2.0 \mathrm{Ma}$ biotite K-Ar age of the gabbroic phase (table 2; KAr 3; Reed and Lanphere, 1972). The presence of mineralized rocks in this phase may point to magnetite-destructive fluids, as the magnetic susceptibility is very low $\left(0.10 \times 10^{-3} \mathrm{SI}\right)$.

\section{ACKNOWLEDGMENTS}

This project was funded by the State of Alaska's Strategic and Critical Minerals Assessment project as part of the Airborne Geophysical/Geological Mineral Inventory program (AGGMI), and managed by the State of Alaska, Department of Natural Resources, Division of Geological \& Geophysical Surveys (DGGS).

This project benefited from unpublished data and discussions with geologists of: The U.S. Geological Survey (USGS) and the Western Alaska Range Project (WARP): Sue Karl, Steve Box, Jamey Jones, Erin Todd, Richard Lease, Garth Graham, Steve Nelson, and Peter Haeussler. Gamble provided an exceptional 1:250,000-scale base map for us to build on from his group's mapping in the 1980's. Insightful property tours, knowledge exchange, and geological data came from: Millrock Resources Inc. (Phil St. George, Kati Gibler), Kiska Metals Corp. (Mike Roberts), WestMountain Gold Inc. (Jim Baughman), and Alaska Earth Sciences (Rob Retherford and Bill Ellis).

Argon dating and helpful discussions were conducted by the UAF Geophysical Lab with Jeff Benowitz and Paul Layer. Erin Todd provided isotope work for the Merrill Pass pluton, and valuable collaboration.

Our lodging, food, and entertainment was provided by the Perrins Family of Rainy Pass Lodge.

Thanks to Loren Leeuw for skilled flying during the field campaign, and to Rusts's Flying Service out of Anchorage for our safe delivery of people and camp supplies. We are grateful to Trish Ekberg and Mike Hendricks for their GIS, database, and cartographic support, and to Simone Montayne for metadata management. Kristen Janssen provided excellent manuscript formatting and layout. We thank Erin Todd and Steve Box for thorough reviews that improved the content and clarity of this report. 


\section{REFERENCES}

Allmendinger, R.W., Cardozo, N.C., and Fisher, D., 2012, Structural Geology Algorithms: Vectors \& Tensors: Cambridge, England, Cambridge University Press, 289 p.

Ayuso, R.A., Haeussler, P.J., Todd, Erin, Box, S.E., Jones, J.V., III, Bradley, D.C., Vazquez, J., Karl, S.M., and Jackson, J., 2014, Geochronological and Geochemical Transects of the Western Alaska Range Batholith: presented at Goldschmidt Annual Conference June 8-13, Sacramento, California, Abstracts, 2014, 89.

Benowitz, J.A., Layer, P.W., and Sicard, K.R., 2014, ${ }^{40} \mathrm{Ar} /{ }^{39} \mathrm{Ar}$ data, Styx River map area, Lime Hills C-1 Quadrangle, Alaska: Alaska Division of Geological \& Geophysical Surveys Raw Data File 2014-21 v. 1.0.1, 13 p. http://doi. org/10.14509/29134

Box, S.E., Karl, S.M., Jones, J.V., III, Bradley, D.C., Haeussler, P.J., and O'Sullivan, P.B., 2019, Detrital zircon geochronology along a structural transect across the Kahiltna assemblage in the western Alaska Range: Implications for emplacement of the Alexander- WrangelliaPeninsular terrane against North America: Geosphere, v. 15, n. 6, p. 1,774-1,808. https://doi. org/10.1130/GES02060.1

Bundtzen, T.K., Eakins, G.R., and Conwell, C.N., 1982, Review of Alaska mineral resources 1981: Alaska Division of Geological \& Geophysical Surveys Annual Report 1981, 48 p., 2 sheets, scale 1:42,240. http://doi.org/10.14509/234

Burns, L.E., Emond, A.M., Fugro Airborne Surveys Corp., and Stevens Exploration Management Corp, 2019, Styx River electromagnetic and magnetic airborne geophysical survey data compilation: Alaska Division of Geological \& Geophysical Surveys Geophysical Report 20192. http://doi.org/10.14509/30166

Cady, W.M., Wallace, R.E., Hoare, J.M., and Webber, E.J., 1955, The central Kuskokwim region, Alaska: U.S. Geological Survey Professional Paper 268, 132 p.

Cardozo, N., and Allmendinger, R.W., 2013, Spherical projections with OSXStereonet: Computers \& Geosciences, v. 51, no. 0, p. 193-205. http://doi.org/10.1016/j.cageo.2012.07.021

Cobb, E.H., and Reed, B.L., 1981, Summaries of data on and lists of references to metallic and selected nonmetallic mineral occurrences in the Iliamna, Lake Clark, Lime Hills, and McGrath quadrangles, Alaska: supplement to Open-file report 76-485; Part A, Summaries to January 1, 1981: U.S. Geological Survey Open-File Report 81-1343-A, 26 p. Colpron, M. and Nelson, J.L., 2011, A Digital Atlas of Terranes for the Northern Cordillera; British Columbia Ministry of Energy and Mines, BCGS GeoFile 2011-11.

Cox, D.P., and Singer, D.A., 1986, Mineral deposit models: U.S. Geological Survey Bulletin 1693, 398 p.

Eakins, G.R., Gilbert, W.G., and Bundtzen, T.K., 1978, Preliminary bedrock geology and mineral resource potential of the west-central Lake Clark Quadrangle, Alaska: Alaska Division of Geological \& Geophysical Surveys, Open-File Report 118, 16 p., 2 sheets, scale 1:125,000. http://doi.org/10.14509/34

Frost, B.R., Barnes, C.G., Collins, W.J., Arculus, R.J., Ellis, D.J., and Frost, C.D., 2001, A geochemical classification for granitic rocks: Journal of Petrology, v. 42, no. 11, p. 2033-2048. Frost, B.R., and Frost, C.D., 2008, A Geochemical Classification for Feldspathic Igneous Rocks: Journal of Petrology, v. 49, no. 11, p. 1,955-1,969.

Gamble, B.M., Reed, B.L., Richter, D.H., and Lanphere, M.A., 2013, Geologic map of the east half of the Lime Hills 1:250,000-scale quadrangle, Alaska: U.S. Geological Survey Open-File Report 2013-1090, scale 1:250,000 and GIS data. http://pubs.usgs.gov/of/2013/1090/

Graham, G.E., Goldfarb, R.J., Miller, M.L., Gibler, K., Roberts, M., 2013, Tectonic evolution and Cretaceous gold metallogenesis of southwestern Alaska in Colpron, N., Bissig, T., Rusk, B.G., Thompson, J.F.H., Tectonics metallogeny, and discovery: The North American cordillera and similar accretionary settings: Society of Economic Geologists Special Publication, v. 17, p. 169-200.

Haeussler, P.J., Bradley, D.C., Ayuso, R.A., Layer, P.W., Friedman, R.M., O’Sullivan, P., Jones, J.V., Karl, S.M., Box, S.E., and Todd, E., 2013, 
Magmatic history of the Tordrillo Mountains and Western Alaska Range and tectonic implications: presented at the 2013 Annual Meeting, Geological Society of America, Denver, Colorado, Abstracts with Programs, Abstract 23-3, v. 45, n. 7 , p. 77.

Hudson, T.L., and Millholland, M.A., 2002, Alaska resource data file, Lime Hills Quadrangle: U.S. Geological Survey Open-File Report 2002-76, 73 p.

Hults, C.P., Wilson, F.H., Donelick, R.A., and O'Sullivan, P.B., 2013, Two flysch belts having distinctly different provenance suggest no stratigraphic link between the Wrangellia composite terrane and the paleo-Alaskan margin: Geological Society of America, Lithosphere v. 5, n. 6, p. 575-594. http://doi.org/10.1130/L310.1

Hung, C.-H., 2008, Zircon U-Pb ages and geochemical characteristics of the McKinley sequence and associated plutons, Central Alaska Range: National Taiwan University, M.S. thesis, 78 p.

Hung, C., Chung, S., Cole, R., Iizuka, Y., Chiu, C., Gallet, S., 2007, Zircon U-Pb ages for the McKinley sequence and associated plutons, Central Alaska Range [abs.]: American Geophysical Union Fall Meeting, 2007, Abstract T11B-0574.

Jones, J.V. III, Todd, E., Box, S.E., Haeussler, P.J., Holm-Denoma, C.S., Ayuso, R.A., and Bradley, D.C., 2014, Late Cretaceous through Oligocene magmatic and tectonic evolution of the western Alaska Range: Presented at the 2014 Annual Meeting, Geological Society of America, Vancouver, Canada: Abstracts with Programs, Abstract 324-4, v. 46, n. 6, p. 781.

Kalbas, J.L., Ridgway, K.D., and Gehrels, G.E., 2007, Stratigraphy, depositional systems, and provenance of the Lower Cretaceous Kahiltna assemblage, western Alaska Range: Basin development in response to oblique collision, in Ridgway, K.D., Trop, J.M., Glen, J.M.G., and O’Neill, J.M., eds., Tectonic Growth of a Collisional Continental Margin: Crustal Evolution of Southern Alaska: Geological Society of America Special Paper 431, p. 307-343. https://doi. org/10.1130/2007.2431(13)
Karl, S.M., Box, S.E., Jones, J.V., III, Holm-Denoma, C., Lease, R.O., Bradley, D.C., and Haeussler, P.J., 2016, Independent Jurassic to Late Cretaceous depositional systems defined by sandstone petrography and detrital zircons constrain closure of the Kahiltna-Kuskokwim basin in southern and southwestern Alaska: Presented at the 2016 Annual Meeting, Geological Society of America, Abstracts with Programs, Abstract 267-23, v. 48, n. 7. http://doi.org/10.1130/abs/2016AM-281104 Karl, S.M., Box, S.E., Jones, J.V., III, Lease, R.O., Bradley, D.C., Haeussler, P.J., Hults, C.P., and Graham, G., 2013, Petrographic and detrital zircon data from the Kahiltna basin suggest Early Cretaceous juxtaposition of the continental margin and the Peninsular terrane in the western Alaska Range: presented at 2013 Annual Meeting, Geological Society of America, Denver, Colorado, Abstracts with Programs, Abstract 23-5, v. 45, No. 7, p. 77.

LeBas, M.J., Maitre, R.W., Streckeisen, A., and Zanettin, B., 1986, A chemical classification of volcanic rocks based on the total alkali-silica diagram: Journal of Petrology, v. 27, p. 745-750.

Lease, R.O., Haeussler, P.J., and O'Sullivan, P., 2016, Changing exhumation patterns during Cenozoic growth and glaciation of the Alaska Range: Insights from detrital thermochronology and geochronology, Tectonics, v. 35, p. 934955. http://doi.org/10.1002/2015TC004067

Lund, K., Snee, L.W., and Evans, K.V., 1986, Age and genesis of precious metals deposits, Buffalo Hump district, central Idaho: implications for depth of emplacement of quartz veins: Economic Geology, v. 81, p. 990-996.

Pearce, J.A., Harris, N.B., and Tindle, A.G., 1984, Trace element discrimination diagrams for the tectonic interpretation of granitic rocks: Journal of Geophysical Research, v. 103, p. 7,171-7,186. Pink, C., 2011, Preliminary report on geologic and structural investigations at the Shoeshine Area, South Estelle Property, Alaska; Yukuskokon Professional Services internal report for Millrock Exploration Corporation, Sept. 26, 2011.

Reed, B.L., and Elliott, R.L., 1970, Reconnaissance geologic map, analyses of bedrock and stream sediment samples, and an aeromagnetic 
map of parts of the southern Alaska Range: U.S. Geological Survey Open-File Report 70-217, 145 p., 1 sheet, scale 1:250,000.

Reed, B.L., and Lanphere, M.A., 1972, Generalized geologic map of the Alaska-Aleutian Range batholith showing potassium-argon ages of the plutonic rocks: U.S. Geological Survey Miscellaneous Field Studies Map MF-372, 2 sheets, scale 1:1,000,000.

Regan, S. P., Benowitz, J. A., and Holland, M. E., 2019, A plutonic brother from another magma mother: Disproving the Eocene Foraker-McGonagall pluton piercing point and implications for long-term slip on the Denali Fault: Terra Nova, p. 1-9. https://doi.org/10.1111/ter.12437

Ridgway, K.D., Trop, J.M., Nokleberg, W.J., Davidson, C.M., and Eastham, K.R., 2002, Mesozoic and Cenozoic tectonics of the eastern and central Alaska Range: Progressive basin development and deformation in a suture zone, Geological Society of America Bulletin: v. 114, n. 12, p. 1480-1504. http://doi.org/10.1130/0016-7606 (2002) 114<1480:MACTOT>2.0.CO;2

Roberts, M., 2014, Copper Joe Executive Summary, Kiska Metals Corporation. (Released January 26, 2014): http://www.kiskametals.com/i/ pdf/Kiska_CopperJoe_ExecutiveSummary_ 26Jan2014.pdf (as of July 11, 2014).

Saltus, R.W., Hudson, T.L, and Wilson, F.H., 2007, The geophysical character of southern Alaska - implications for crustal evolution, in Ridgway, K.D., Trop, J.M., Glen, J.M.G., and O'Neill, J.M., eds., Tectonic Growth of a Collisional Continental Margin: Crustal Evolution of Southern Alaska: Geological Society of America Special Paper 431, p. 1-20. doi. org/10.1130/2007.2431(01)

Sicard, K.R., Twelker, Evan, Freeman, L.K., Bachmann, E.N., Reioux, D.A., Tuzzolino, A.L., Wright, T.C., Newberry, R.J., Burns, L.E., and Werdon, M.B., 2013, Geologic mapping in the Styx River area, Lime Hills C-1 Quadrangle, western Alaska Range (presentation): Alaska Miners Association Annual Convention, Anchorage, Alaska, November 4-10, 2013: Alaska Division of Geological \& Geophysical Surveys,
25 p. http://doi.org/10.14509/26803

Sicard, K.R., Twelker, E., Freeman, L.K., Wypych, E., Benowitz, J.A., and Kass, M.A., P.W., 2014a, Cretaceous to Tertiary magmatism and associated mineralization in the Lime Hills C-1 Quadrangle, western Alaska Range: Geological Society of America Annual Meeting in Vancouver, Canada; Abstracts with Programs, v. 46, n. 6, p. 795.

Sicard, K.R., Wypych, Alicja, Twelker, Evan, Bachmann, E.N., Freeman, L.K., Newberry, R.J., Reioux, D.A., Tuzzolino, A.L., and Wright, T.C., 2014b, Major-oxide, minor-oxide, and trace-element geochemical data from rocks in the Styx River area, Lime Hills C-1 Quadrangle, Lime Hills, McGrath, Talkeetna, and Tyonek quadrangles, Alaska: Alaska Division of Geological \& Geophysical Surveys Raw Data File 2014-6, 4 p. http://doi.org/10.14509/27289

Sicard, K.R., Wypych, Alicja, Twelker, Evan, Freeman, L.K., Bachmann, E.N., Reioux, D.A., Tuzzolino, A.L., and Wright, T.C., 2014c, Geochemistry and petrology of igneous rocks from the Styx River map area (presentation): Alaska Miners Association 24th Biennial Mining Conference, April 7-14, 2014, Fairbanks, Alaska: Alaska Division of Geological \& Geophysical Surveys, 36 p. http://doi.org/10.14509/27312

Sun, S.S., and McDonough, W.F., 1989, Chemical and isotopic systematics of oceanic basalts: implications for mantle composition and processes: Geological Society, London, Special Publications, v. 42, n. 1, p. 313-345.

Taylor, R.D., Graham, G.E., Anderson, E.D., and Selby, David, 2014, Timing of ore-related magmatism in the western Alaska Range, southwestern Alaska: U.S. Geological Survey OpenFile Report 2014-1115, 25 p. http://dx.doi. org/10.3133/ofr20141115.

Todd, Erin, and Jones, J.V., 2017, Distinct magmatic stages associated with Cretaceous through Paleogene crustal formation and evolution of the southern Alaska margin, Geological Society of America, Annual Meeting in Seattle, WA; Abstracts with Programs: v. 49, n. 6. http://doi. org/10.1130/abs/2017AM-304280

Todd, Erin, Kylander-Clark, A., Wypych, A., 
Twelker, Evan, and Sicard, K.R., 2017, U-Pb and $\mathrm{Lu}-\mathrm{Hf}$ isotope, age, and trace-element data from zircons at four sites in the western Alaska Range and Talkeetna Mountains, Alaska: Alaska Division of Geological \& Geophysical Surveys Raw Data File 2017-2, 7 p. http://doi. org/10.14509/29717

Wallace, W.K., Hanks, C.L., and Rogers, J.F.,
1989, The southern Kahiltna terrane-Implications for the tectonic evolution of southwestern Alaska: Geological Society of America Bulletin, v. 101, p. 1,389-1,407.

Wilson, Marjorie, 1989, Igneous petrogenesis: a global tectonic approach. Unwin Hyman, London, 466 p. http://doi.org/10.1007/978-14020-6788-4 


\section{APPENDIX \\ MINERAL OCCURRENCES, UPDATED ARDF OCCURRENCES \\ Unnamed (head of South Fork Kuskokwim River); Orange Ridge}

Site

Unnamed (head of South Fork Kuskokwim River); Orange Ridge

ARDF no.

LH019RevB 8/2017

Site type

Occurrence

Site status

Inactive

Production ( $\mathrm{Y} / \mathrm{N})$

None

quad-250

Lime Hills

quad-63360

C-1

Latitude

61.5724

Longitude

153.3129

\section{Location}

This occurrence is at an elevation of about 6,500 feet (1,980 meters) on a ridge along the east side of the southeast headwater tributary of South Fork Kuskokwim River. The site is 0.5 kilometer southsouthwest of peak 6980, in the southwest corner of section 8, T 17 N, R 22 W, of the Seward Meridian. This is locality 10 of Cobb (1972 [MF 412]; 1976 [OF 76-485]). The coordinates are those of a centrallylocated mineralized outcrop relocated by the Alaska Division of Geological \& Geophysical Surveys using handheld GPS location accurate to approximately 10 meters.

\section{Main commodities}

$\mathrm{Ag}, \mathrm{Au}, \mathrm{Cu}$

Other commodities

Ore minerals

Arsenopyrite, chalcopyrite, pyrite

\section{Gangue minerals}

Carbonate minerals, epidote, quartz, sericite, tourmaline

\section{Geologic description}


The occurrence is associated with a seriate quartz monzonite stock (Taylor and others, 2014) intruding

the Late Cretaceous South Fork pluton and turbiditic sedimentary rocks of Cretaceous age (Gamble and others, 2013).

Reed and Elliott (1970) reported that sparse fractures as much as 1-cm-wide in quartz monzonite are filled with quartz, chalcopyrite, pyrite, and traces of other sulfide minerals. Arsenopyrite also occurs in some veins (Taylor and others, 2104). Other vein-hosted accessory minerals include carbonate minerals \pm sericite \pm tourmaline \pm epidote (Sicard and other, 2014). Pyrite and chalcopyrite are also disseminated in the quartz monzonite (Reed and Elliott, 1970), which Taylor and others (2014) describe as extensively sericitized, silicified, and strongly iron-stained. A sample of a vein reported by Reed and Elliott (1970) contained greater than 20,000 parts per million (ppm) copper, $100 \mathrm{ppm}$ silver, and anomalous lead. A sample of quartz-chalcopyrite-pyrite vein material carried 1.97 percent copper, $56.9 \mathrm{ppm}$ silver, $0.296 \mathrm{ppm}$ gold, $1,110 \mathrm{ppm}$ arsenic, $815 \mathrm{ppm}$ zinc, $33.2 \mathrm{ppm}$ bismuth, and $13.6 \mathrm{ppm}$ indium (sample 13LF175A of Sicard and others, 2014).

Taylor and others (2014) determined a U-Pb zircon age of $68.0 \pm 1.1 \mathrm{Ma}$ for a least-altered example of extensively sericitized and silicified, strongly orange-colored intrusive rock in the vicinity of the occurrence. The sample dated was barren of sulfides and quartz veins. The veining and mineralization appears to be associated with this intrusion and is therefore likely latest Cretaceous to early Tertiary in age.

The occurrence most closely resembles a copper-gold porphyry system (e.g. Cox and Singer, 1986, model 20c) because of its association with a quartz monzonite stock, veinlet- and fracture-controlled quartz and sulfides, chalcopyrite-pyrite sulfide assemblage, and quartz-sericite-pyrite alteration.

\section{Alteration of deposit}

Sericitization and silicification of the country rock accompany quartz veining and sulfide mineralization (Taylor and others, 2014).

\section{Age of mineralization}

Latest Cretaceous to early Tertiary; the mineralization is localized in veinlets cutting (and likely related to) intrusive rocks dated at $68.0 \pm 1.1 \mathrm{Ma}$ by U-Pb zircon (Taylor and others, 2014).

\section{Mineral deposit model}

Porphyry copper-gold (Cox and Singer, 1986, model 20c).

\section{Mineral deposit number}

$20 \mathrm{c}$

\section{Generic deposit model}

Porphyry deposits (Einaudi and others, 2005).

\section{Workings or exploration}

Reconnaissance mapping and sampling has been completed in this area by the U.S. Geological Survey (Reed and Elliott, 1970; Taylor and others, 2014), and the Alaska Division of Geological \& Geophysical Surveys (Sicard and others, 2014). The area was staked in 2007 during regional exploration by Anglo American Exploration.

Reed and Elliott (1970) reported a sample of a vein contained greater than 20,000 ppm copper, 100 ppm silver, and anomalous lead.

A sample of quartz-chalcopyrite-pyrite vein material carried 1.97 percent copper (19,700 ppm), 56.9 
ppm silver, $0.296 \mathrm{ppm}$ gold, 1,110 ppm arsenic, $815 \mathrm{ppm}$ zinc, $33.2 \mathrm{ppm}$ bismuth, and $13.6 \mathrm{ppm}$ indium (sample 13LF175A of Sicard and others, 2014).

\section{Production notes}

None

Reserves

None

\section{Primary reference}

Reed and Elliot, 1970

\section{Reporters}

Travis L. Hudson (Applied Geology) and Madelyn A. Millholland (Millholland \& Associates); Evan Twelker (DGGS)

\section{Last report date}

8/18/2017

\section{Additional comments}

Taylor and others (2014) refer to the occurrence informally as "Orange Ridge." 


\section{Copper Joe}

Site

Copper Joe

Commodities, main

$\mathrm{Ag}, \mathrm{Au}, \mathrm{Cu}, \mathrm{Mo}$

Quad-250

$\mathrm{LH}$

Quad-63360

C-1

Latitude

61.5415

Longitude

153.1590

\section{Location}

The Copper Joe prospect encompasses an approximately 2.5 by $4.5 \mathrm{~km}$ zone of alteration and mineralization at an elevation of about 3,700 to 4,300 feet (1,130 to 1,310 m) along two unnamed east-flowing tributaries to the upper Styx River. It is spread over sections 19 and 30 of T. 17 N., R. 21 W., and sections 23 through 26 of T. 17 N., R. 22 W. of the Seward Meridian. The coordinates refer to the discovery outcrop and drill site in what is informally named Hades Gulch; additional mineralized outcrops are found along another unnamed tributary, informally named Frost Creek, approximately $1.9 \mathrm{~km}$ to the west-northwest.

\section{Commodities, other}

$\mathrm{Pb}, \mathrm{Zn}$

\section{Ore minerals}

Chalcopyrite, galena, gold, hematite, magnetite, molybdenite, pyrite, sphalerite gangue minerals

Anhydrite, biotite, quartz, sericite

Site type

Prospect

Site status

Active

\section{Production}

None

\section{Deposit model}

Copper-gold-molybdenum porphyry? (Cox and Singer, 1986, model 20c or 21a).

\section{Geologic description}

The Copper Joe prospect consists of Miocene ( $\pm 11 \mathrm{Ma}$; Benowitz and others, 2014) porphyry copper-style alteration, veins, and hydrothermal breccias with a footprint of greater than $10 \mathrm{~km}^{2}$ in the 
upper Styx River drainage. The prospect is hosted by plutonic country rock assigned to the Paleocene ( $\pm 60 \mathrm{Ma}$; Todd and others, 2017) Merrill Pass pluton of Gamble and others (2013). At property scale, the plutonic country rocks are mapped as medium-grained hornblende-biotite granodiorite, intruded in the immediate prospect vicinity by medium to coarse-grained quartz monzonite. On the north side of Frost Creek, north of the prospect, the quartz monzonite is intruded by porphyritic to megacrystic hornblende-biotite granite. Syn- and post-mineralization dikes and stocks of Miocene felsic biotite porphyry are exposed near the center of the prospect area (Roberts, unpub. data, 2014). Rhyolite flows are exposed on ridges above the prospect. Gamble and others (2013) map these as part of the Oligocene to Eocene volcanic fields of the western Alaska Range; however, Roberts (unpub. data, 2014) observes that they are not affected by alteration at the prospect and suggests they are younger than $11 \mathrm{Ma}$. All units are cut by thin biotite-plagioclase porphyry dikes of intermediate composition.

The Copper Joe prospect comprises two main showings that expose different parts of a larger alteration system. Potassic-type veining and breccias are exposed at Frost Creek and are thought to represent a northeasterly trending potassic altered zone approximately $1400 \mathrm{~m}$ by $600 \mathrm{~m}$. Partial to pervasive and texturally destructive quartz-sericite-pyrite alteration is well exposed at Hades Gulch, $1.7 \mathrm{~km}$ to the southeast of Frost Creek; this alteration style is mapped in outcrop and induced-polarization (IP) geophysical surveys as a broad zone of approximately 2.5 by $4.5 \mathrm{~km}$ surrounding and partially overprinting the Frost Creek potassic alteration zone (Roberts, unpub. data, 2014).

The Frost Creek showing consists of discontinuously exposed outcrops along $1400 \mathrm{~m}$ of the eastflowing creek at the latitude and longitude of this occurrence. In this area, both plutonic country rock and some porphyry dikes locally contain 2-5 percent 'A' style quartz veinlets, potassic alteration (potassium feldspar and biotite) and locally, disseminated chalcopyrite. Some of these veinlets are cut by banded quartz-magnetite veins. This alteration and veining is also spatially associated with 1) magnetite-cemented monolithic breccias in potassium feldspar-quartz-magnetite altered plutonic rock with trace chalcopyrite, 2) biotite-cemented breccias in potassium feldspar-biotite altered porphyry with trace chalcopyrite, 3) bleached to maroon heterolithic rock flour-cemented breccias with sericite-hematite altered matrix. The rock flour-cemented breccia contains fragments of quartz-magnetite veins. The area of magnetite-bearing alteration is coincident with a $1400 \mathrm{~m}$ long, $600 \mathrm{~m}$ wide anomaly in the airborne magnetic data (Roberts, unpub. data, 2014). Out of 27 rock grab samples collected from the Frost Creek showing, 25 returned values less than 0.1 percent copper; the best results were from a sericite-chlorite altered heterolithic rock flour breccia, which assayed 0.24 percent copper (Roberts, unpub. data, 2014). A sample of quartz-sulfide veinlets and sericitized wall rock in the Frost Creek area carried 0.85 percent copper, 31.9 ppm silver, 0.125 ppm gold, and $11.1 \mathrm{ppm}$ tellurium (Sicard and others, 2014). Drilling in the Frost Creek area intercepted hydrothermal and rock flour breccias, alteration, and trace chalcopyrite mineralization (Kiska Metals Corp., written commun., 2014).

At the Hades Gulch showing, an incised stream cut exposes a zone of partial to pervasive (texturally destructive) quartz-sericite-pyrite alteration (termed 'phyllic' by Roberts [unpub. data, 2014]) and associated ' $D$ ' style quartz-pyrite \pm molybdenite \pm sphalerite \pm galena veins and local quartz-molybdenite veins. The alteration affects both plutonic country rock and biotite porphyry dikes and stocks several meters to tens of meters wide, which are interpreted by Roberts (unpub. data., 2014) as coeval to mineralization. The pyritic nature of this alteration is underscored by an up-to-8 m-thick blanket of Quaternary ferricrete in Hades Gulch. Syn- and post-alteration biotite porphyry dikes and stocks several meters to tens of meters wide outcrop at this showing as well. Drilling in the Hades Gulch area intercepted nine 10 foot $(3 \mathrm{~m})$ 
intervals of greater than 100 ppm molybdenum with associated anomalous (200-950 ppm) copper values, silver up to $46 \mathrm{ppm}$, and elevated lead and zinc (Roberts, unpub. data, 2014). A hole drilled between Frost Creek and Hades gulch intercepted a $400 \mathrm{~m}$ zone of hydrothermal breccia with strong phyllic alteration, abundant pyrite, and sparse 'early' quartz veins, magnetite-anhydrite-pyrite-chalcopyrite veins, and banded molybdenite veins (Kiska Metals Corp., written commun., 2016).

Ar/Ar dating of alteration sericite at the Hades Gulch showing indicates that the hydrothermal system is Miocene in age. Alteration sericite from within a strongly altered felsite dike yielded an age of $11.5 \pm 0.1$ $\mathrm{Ma}$, and sericite from the selvage of a chalcopyrite-bearing quartz veinlet cutting plutonic country rock returned an age of $10.7 \pm 0.1 \mathrm{Ma}$ (Benowitz and others, 2014). Unpublished geochronology referenced by Roberts (unpub. data, 2014) indicates that 'syn-mineral' (strongly altered) biotite porphyry dikes have a K-Ar age of $11.3 \pm 0.5 \mathrm{Ma}$, while similar (but unaltered) 'post-mineral' dikes yielded a K-Ar age of 9.9 $\pm 0.4 \mathrm{Ma}$.

\section{Workings/exploration}

The first published record of the prospect is by Reed and Elliott (1970), who described and sampled iron-stained and altered intrusive rocks present along about 200 feet of a creek. The altered rocks consist dominantly of quartz and sericite with minor potassium feldspar and biotite. These rocks generally contain less than one percent sulfide minerals, including pyrite, sphalerite, and galena, which are disseminated and in quartz veins as much as 2 inches wide. Sphalerite and galena also occur as thin veinlets and disseminations in felsite. Shear zones in the altered intrusions are also mineralized with sulfides. Besides zinc and lead values, rock samples contained as much as 15 ppm silver and 300 ppm molybdenum (Reed and Elliott, 1970).

According to Roberts (unpub. data, 2014), the initial exploration was completed by Amax Exploration Inc. (AMAX) in 1979 and 1980. AMAX drilled three diamond drillholes totaling 1,500 feet (457 $\mathrm{m})$ in the quartz-sericite-pyrite alteration zone at Hades Gulch, intercepting nine 10-foot $(3 \mathrm{~m})$ intervals assaying greater than 100 ppm molybdenum, with associated anomalous (200-950 ppm) copper values, silver up to $46 \mathrm{ppm}$, and elevated lead and zinc; samples were not assayed for gold (Roberts, unpub. data, 2014).

In 2006, Kennecott Exploration staked 100 State of Alaska mining claims over this prospect, which they interpreted to have porphyry-style alteration in porphyritic monzodiorite rocks (Kiska Metals Corporation, written commun., 2010). Kennecott did a ground magnetic survey that defined a magnetic high about 1.0 by 1.9 kilometers in area that trends northeast from the mineralization. Rock samples contained up to 0.73 percent copper, 0.415 ppm gold, and 0.125 percent molybdenum.

In 2010, Kiska Metals Corp. (Kiska) signed an option agreement with Kennecott to explore the Copper Joe claims. Exploration work conducted by Kiska consisted of geological mapping, rock, soil and stream sediment geochemistry sampling, and an induced-polarization (IP) survey and ground magnetics around a prospective area defined in previous work by AMAX and Kennecott. In 2011, a short follow-up program was conducted on Copper Joe that consisted of geological mapping, rock geochemistry sampling, and prospecting. At this time, new claims were staked (Shogun Claims) to the northwest of the Copper Joe claims covering drainages with anomalous copper and gold in stream sediment samples collected in 2010 (Roberts, unpub. data, 2014).

Kiska and First Quantum Minerals Ltd. (First Quantum) drilled two holes totaling 885 meters at Copper Joe in 2014. Drilling did not return any significant assay results but did confirm a large porphy- 
ry-hydrothermal system. One drill hole intersected two zones of heterolithic, magnetite breccia cross-cutting a porphyritic quartz monzonite and the other drill hole intersected a moderately to strongly chlorite-epidote altered quartz monzonite breccia intruded by a weakly altered biotite-feldspar porphyry (Kiska Metals Corp., written commun., 2014). Exploration work in 2015 included a magnetotelluric geophysical survey and infill geologic mapping (Kiska Metals Corp., written commun., 2015). In 2016, Kiska and First Quantum drilled a single $805 \mathrm{~m}$ hole targeting the center of $1.4 \mathrm{~km}$ magnetotelluric geophysical anomaly between Frost Creek and Hades gulch. The hole did not return any significant assay results, however it did intercept over $400 \mathrm{~m}$ of hydrothermal breccia with strong phyllic alteration, abundant pyrite, and sparse 'early' quartz veins, magnetite-anhydrite-pyrite-chalcopyrite veins, and banded molybdenite veins. First Quantum withdrew from the project following this result (Kiska Metals Corp., written commun., 2016).

\section{Additional comments}

\section{ARDF number}

LH020

\section{Reporter(s)}

Travis L. Hudson (Applied Geology) and Madelyn A. Millholland (Millholland \& Associates); D.J. Grybeck (Contractor, USGS); V.C. Zinno (Alaska Earth Sciences, Inc.); N.V. King (Alaska Earth Sciences, Inc.); Evan Twelker (DGGS)

\section{Last report date}

$11 / 30 / 2017$

\section{MRDS number}

\section{Age}

Miocene (around $11 \mathrm{Ma}$ ) based on ${ }^{40} \mathrm{Ar} /{ }^{39} \mathrm{Ar}$ dating of alteration sericite (Benowitz and others, 2014).

\section{Deposit model number}

20 c or $21 \mathrm{a}$

\section{Generic deposit model}

Porphyry deposits (Einaudi and others, 2005)

\section{Alteration}

A core zone of magnetite-bearing potassic (biotite and potassium feldspar) alteration associated with porphyry dikes; this alteration includes both replacement and vein- or breccia-infill styles. The potassic zone is surrounded and partially overprinted by an extensive 4.5 by 2.5 kilometer zone of moderate to intense quartz-sericite-pyrite alteration and quartz-pyrite veinlets (Roberts, unpub. data, 2014).

\section{Production notes}

None

\section{Reserves}

None 


\section{Unnamed (4 miles southwest of Jimmy Lake)}

Site

Unnamed (4 miles southwest of Jimmy Lake)

ARDF no.

Styx01

Site type

Occurrence

Site status

Inactive

Production (Y/N)

None

quad-250

Lime Hills

quad-63360

C-1

Latitude (WGS84)

61.6844

Longitude (WGS84)

153.3260

\section{Location}

Mineralization occurs along an incised, northwest-flowing tributary of the South Fork of the Kuskokwim River, 4 miles southwest of Jimmy Lake. It is in the northeast quarter of section 6, T. 18 N., R., 22 W., of the Seward Meridian. The location is by handheld GPS accurate to approximately 10 meters.

\section{Main commodities}

$\mathrm{Au}$

\section{Other commodities}

Ore minerals

Pyrite

\section{Gangue minerals}

Quartz

\section{Geologic description}

Granite of the Merrill Pass pluton in this area is cut by sparse quartz veinlets. Alteration is characterized by chloritization of mafic minerals, with one 20 meter zone of gossanous, clay- or sericite-altered granite. A sample of granite with quartz veinlets assayed $1.49 \mathrm{ppm}$ gold and carried anomalous tellurium (5.09 ppm) and bismuth (39.2 ppm) (sample 13RN264A of Sicard and others, 2014). 


\section{Alteration of deposit}

Chloritization of mafics and clay or sericite alteration of feldspars.

\section{Age of mineralization}

Paleocene or younger, based on the age of the host Merrill Pass pluton.

\section{Mineral deposit model}

Intrusion-related gold

\section{Mineral deposit number}

\section{Workings or exploration}

Only surface sampling by the Alaska Division of Geological \& Geophysical Surveys is known.

\section{Production notes}

\section{Reserves}

\section{Primary reference}

This record

\section{Reporters}

Evan Twelker (DGGS)

\section{Last report date}

03/27/2017

\section{Additional comments}




\section{Unnamed (western edge of Estelle pluton)}

Site

Unnamed (western edge of Estelle pluton)

ARDF no.

Styx02

Site type

Occurrence

Site status

Inactive

Production (Y/N)

None

quad-250

Lime Hills

quad-63360

C-1

Latitude (WGS84)

61.7168

Longitude (WGS84)

153.0608

\section{Location}

This occurrence is located on a ridgeline at about 5,500 feet elevation between unnamed creeks draining northwest into the Styx River in the northeastern corner of the Lime Hills C-1 quadrangle. It is in the southwest quarter of section 22, T. 19 N., R., 21 W., of the Seward Meridian. The location is by handheld GPS accurate to approximately 10 meters.

\section{Main commodities}

$\mathrm{Au}, \mathrm{Cu}$

\section{Other commodities}

\section{Ore minerals}

Chalcopyrite, pyrite, pyrrhotite

\section{Gangue minerals}

Actinolite, carbonate, chlorite, quartz, tourmaline

\section{Geologic description}

Gold-copper mineralization occurs at the western margin of the Mount Estelle pluton and approximately 500 meters into the adjacent gossanous hornfels country rock, which is cut by a series of thin dikes. Mineralization consists of low sulfide quartz-carbonate-chlorite veinlets in granite and about 5 percent total disseminated pyrite-pyrrhotite-chalcopyrite sulfide in hornfels. A sample granite cut by quartz-car- 
bonate mineral veinlets assayed $3.45 \mathrm{ppm}$ gold (sample 13EB048A of Sicard and others, 2014). Three mineralized hornfels samples ranged from 0.132 to $0.282 \mathrm{ppm}$ gold and 415 to $1025 \mathrm{ppm}$ copper (Sicard and others, 2014). Silver, bismuth, tellurium, and arsenic are not anomalous.

\section{Alteration of deposit}

Propylitic assemblage of chlorite, actinolite, and carbonate; local tourmaline.

\section{Age of mineralization}

Late Cretaceous, based on the inferred relationship to the 66-70 Ma Mount Estelle pluton (Taylor and others, 2014)

\section{Mineral deposit model}

Intrusion-related gold

\section{Mineral deposit number}

\section{Workings or exploration}

Geologists from the DGGS sampled this occurrence during the 2013 field program. The area was staked in 2008 during regional exploration by Anglo American Exploration and again by Millrock Resources Inc. in 2011. No results specific to this occurrence are publicly available.

\section{Production notes}

\section{Reserves}

\section{Primary reference}

This record

\section{Reporters}

Evan Twelker (DGGS)

\section{Last report date}

03/27/2017

\section{Additional comments}




\section{REFERENCES}

Benowitz, J.A., Layer, P.W., and Sicard, K.R., 2014, ${ }^{40} \mathrm{Ar} /{ }^{39} \mathrm{Ar}$ data, Styx River map area, Lime Hills C-1 Quadrangle, Alaska: Alaska Division of Geological \& Geophysical Surveys Raw Data File 2014-21 v. 1.0.1, 13 p. http://doi.org/10.14509/29134

Cobb., E.H., 1972, Metallic mineral resources map of the Lime Hills Quadrangle, Alaska: U.S. Geological Survey Miscellaneous Field Studies Map 412, 1 sheet, scale 1:250,000.

Cox, D.P., and Singer, D.A., eds., 1986, Mineral deposit models: U.S. Geological Survey Bulletin 1693, $379 \mathrm{p}$.

Einaudi, M.T., Zurcher, Lukas, Stavast, W.J.A., Johnson, D.A., and Barton, M.D., 2005, Porphyry deposits: Characteristics and origin of hypogene features, in Hedenquist, J.W., Thompson, J.F.H., Goldfarb, R.J., and Richards, J.P., eds., Economic Geology, One hundredth anniversary volume, 1905-2005: Society of Economic Geologists, Littleton, Colorado, p. 251-298.

Gamble, B.M., Richter, D.H., and Lanphere, M.A., 2013, Geologic map of the east half of the Lime Hills 1:250,000-scale quadrangle, Alaska: U.S. Geological Survey Open-File Report 2013-1090, 1 sheet, scale 1:2,500,000. http://pubs.usgs.gov/of/2013/1090/

Hudson, T.L., and Millholland, M.A., 2002, Alaska resource data file, Lime Hills Quadrangle: U.S. Geological Survey Open-File Report 2002-76, 73 p.

Reed, B.L., and Elliott, R.L., 1970, Reconnaissance geologic map, analyses of bedrock and stream sediment samples, and an aeromagnetic map of parts of the southern Alaska Range: U.S. Geological Survey Open-File Report 70-217, 145 p., 1 sheet, scale 1:250,000.

Sicard, K.R., Wypych, Alicja, Twelker, Evan, Bachmann, E.N., Freeman, L.K., Newberry, R.J., Reioux, D.A., Tuzzolino, A.L., and Wright, T.C., 2014, Major-oxide, minor-oxide, and trace-element geochemical data from rocks in the Styx River area, Lime Hills C-1 Quadrangle, Lime Hills, McGrath, Talkeetna, and Tyonek quadrangles, Alaska: Alaska Division of Geological \& Geophysical Surveys Raw Data File 2014-6, 4 p. http://doi.org/10.14509/27289

Taylor, R.D., Graham, G.E., Anderson, E.D., and Selby, David, 2014, Timing of ore-related magmatism in the western Alaska Range, southwestern Alaska: U.S. Geological Survey Open-File Report 20141115, 25 p. https://pubs.usgs.gov/of/2014/1115/

Todd, Erin, Kylander-Clark, Andrew, Wypych, Alicja, Twelker, Evan, and Sicard, K.R., 2017, U-Pb and $\mathrm{Lu}-\mathrm{Hf}$ isotope, age, and trace-element data from zircons at four sites in the western Alaska Range and Talkeetna Mountains, Alaska: Alaska Division of Geological \& Geophysical Surveys Raw Data File 2017-2, 7 p. http://doi.org/10.14509/29717 